Florida International University FIU Digital Commons

$11-5-1998$

\title{
Comparative reproductive biology of two Florida pawpaws asimina reticulata chapman and asimina tetramera small
}

Anne Cheney Cox

Florida International University

DOI: $10.25148 /$ etd.FI14061532

Follow this and additional works at: https://digitalcommons.fiu.edu/etd

Part of the Biology Commons

\section{Recommended Citation}

Cox, Anne Cheney, "Comparative reproductive biology of two Florida pawpaws asimina reticulata chapman and asimina tetramera small" (1998). FIU Electronic Theses and Dissertations. 2656.

https://digitalcommons.fiu.edu/etd/2656 
FLORIDA INTERNATIONAL UNIVERSITY

Miami, Florida

\title{
COMPARATIVE REPRODUCTIVE BIOLOGY OF \\ TWO FLORIDA PAWPAWS ASIMINA RETICULATA CHAPMAN \\ AND ASIMINA TETRAMERA SMALL
}

\author{
A dissertation submitted in partial fulfillment of the \\ requirements for the degree of \\ DOCTOR OF PHILOSOPHY \\ in
}

BIOLOGY

by

Anne Cheney Cox

1998 
To: Arthur W. Herriott

College of Arts and Sciences

This dissertation, written by Anne Cheney Cox, and entitled Comparative Reproductive Biology of Two Florida Pawpaws, Asimina reticulata Chapman and Asimina tetramera Small, having been approved in respect to style and intellectual content, is referred to you for judgement.

We have read this dissertation and recommend that it be approved.

Jorge E. Peña

Steven F. Oberbauer

Bradley C. Bennett

Daniel F. Austin

Suzanne Koptur, Major Professor

Date of Defense: November 5, 1998

The dissertation of Anne Cheney Cox is approved.

Dean Arthur W. Herriott College of Arts and Sciences

Dr. Richard L. Campbell Dean of Graduate Studies

Florida Intemational University, 1998 


\section{DEDICATION}

I dedicate this dissertation to my children Ernie, Elaine, and Laura, who

have been my enthusiastic supporters, encouraging me every step of the way.

And to my grandchildren, E. J., Steven, Peter, Thomas, Daniel, and Courtney who have given me love, laughter, and new perspectives. 


\section{ACKNOWLEDGMENTS}

Since the summer of 1994 I have had a number of field assistants and collaborators on the Pawpaw Project. They have all contributed in some way to the success of this project and each person has given me the support I needed at the right time. I appreciate the involvement of my major professor, Suzanne Koptur and committee members Brad Bennett (FIU), Steve Oberbauer (FIU), Jorge Peña (IFAS-TRES UF), and Daniel Austin (FAU). I thank my fellow classmates at FIU: Hong Liu, John Geiger, Suzanne Kennedy, Sherine El-Sawa, Cristina Rodriquez, Maureen Sullivan, and Cheryl Hardick. Several long time friends and fellow students from FAU offered continuous support: Judy Hicklin, Chris Lockhart, Sandy Cummings Mann, and Layne Bolen.

Through my collaboration with Richard E. Roberts, JDSP Biologist, and the Resource Management Project, I have had a wide variety of field assistants from the Jonathan Dickinson State Park. I am honored that Roy Woodbury, retired botanist from the University of Puerto Rico, shared his expert knowledge with me in the field. Park rangers patrolled the pawpaw patch and Ranger Bob Schuh helped with site preparation. David Martin, of the USFWS, provided suggestions early in the planning phase of the resource management study. Student Conservation Association members Dave Bowne, helped with both projects in 1995; Darren Stewart assisted in 1996; and Denise Jansen in 1997. Judy Norton, wildlife photographer, took 
photographs for the JDSP Project and poster and assisted with initial field surveys. In addition to providing collaboration and volunteer assistance, Dick Roberts made provisions for me to live at Jonathan Dickinson State Park since July 1994 and has given me the needed feedback.

Many people helped on the Resource Management Project: Geoff Babb, and The Nature Conservancy fire team; the JDSP fire team; Sue Husari, USDA Forest Service; and Kevin Walsh. I thank Judy Norton, Helen Beers, and Amanda Clough for their help with field surveys; Alana Edwards for editorial assistance; Marthanne Mitchell, Laura Sylvester, and the students in the Jupiter High School Environmental Research and Field Studies Academy for their help counting pine seedlings; Sharon Richards, Sam Tollefson, Lorraine Roberts, Sandy Baily and the JDSP Interpretive Association for their long term support of this project.

Others who have assisted on the Diamondhead Radnor Park include Mike "Sherpa" Byrne who followed in my footsteps to graduate school at FIU and Lyn Getys, field assistant and flower illustrator. Several members of the Palm Beach County Native Plant Society have assisted me in the field; Bill Lowery, Marvin Greenberg, Terry Walker, and Bonnie Deutsche helped with mapping and flowering data; Al Vazquez generated all the site drawings. Richard Moyroud, who initiated the listing of the four-petal pawpaw in 1985 , introduced me to these plants in 1980 and provided valuable insight.

Palm Beach County Departments of Parks and Recreation and 
Environmental Resources Management provided me with maps and ecological information on the County-owned sites. Parks and Recreation Volunteer Coordinator, Lisa Rykert provided volunteers to assist at Diamondhead Radnor Park

I especially thank Paul Mikkelsen, for providing computer expertise and critically editing my manuscripts. Dr. Alan Willsie spent many hours with me on biological discussions and gave me editorial assistance with figures and tables. Dr. Raysa Richardson assisted in spiritual guidance at FIU and Dr. Paulette Johnson provided statistical analysis expertise. Dr. Mike Thomas identified the insect specimens (FDACS, Department of Plant Industry) and Ann Murray drew the Asimina illustrations (IFAS, Center for Aquatic Plants Information Office).

This study was supported by U.S. Fish and Wildlife Service Endangered Species Grant \#1448-004-93-967. The Resource Management project was funded by U.S. Fish and Wildlife Service Endangered Species Grant \#1448-0004-94-9122. 


\title{
ABSTRACT OF THE DISSERTATION
}

\author{
COMPARATIVE REPRODUCTIVE BIOLOGY OF TWO \\ FLORIDA PAWPAWS ASIMINA RETICULATA CHAPMAN
}

AND ASIMINA TETRAMERA SMALL

by

Anne Cheney Cox

Florida International University, 1998

Miami, Florida

Professor Suzanne Koptur, Major Professor

I investigated the phenology and breeding systems of two Florida endemic pawpaws, Asimina reticulata, widespread in peninsular Florida, and $A$. tetramera, a federally endangered species limited to two counties on the Atlantic Coastal Ridge. The purpose of this study was to determine if differences contribute to the rarity of Asimina tetramera compared with $A$. reticulata. The study was conducted in sand pine scrub sites with the largest populations of $A$. tetramera in the two counties. Flowering seasons differ for the two species. Both species are hermaphroditic and strongly protogynous. Pollination experiments show that neither species is autogamous and the primary breeding mechanism is outcrossing, although low levels of 
geitonogamous pollination occur in mature scrub habitats. High levels of inbreeding depression were noted in both species at both sites but inbreeding depression was relaxed the first year post-fire. Fruit set in mature habitats may be pollinator limited.

I studied insects associated with the flowers in sand pine scrub habitat in southeastern Florida from 1994-1996. The most commonly represented orders were Coleoptera (25 spp.), Lepidoptera (3 spp.) and Hymenoptera (3 spp.). All Coleoptera were flower visitors; one species, Euphoria sepulchralis (Fabricius) (Scarabeaidae), visited flowers of the two Asimina species at both sites. Eurytides marcellus (Cramer) (Lepidoptera: Papilionidae) eggs and larvae were observed on both species of Asimina during each year of the study.

Resource management techniques were applied to a mature sand pine scrub community in Jonathan Dickinson State Park in southeastern Florida for the management of Asimina tetramera. Manipulations conducted in 1996 included combinations of fire and mechanical treatments. I measured effects of these treatments on flowering and fruit-set on $A$. tetramera and found the fire treatments, BURN and CUT\&BURN, significantly increased flowering. Mechanical treatments cutting and mulching had no significant effect. 
I: THE FLOWERING PHENOLOGY AND REPRODUCTIVE BIOLOGY IF TWO ENDEMIC FLORIDA PAWPAWS:

ASIMINA RETICULATA AND ASIMINA TETRAMERA $\ldots \ldots \ldots 1$

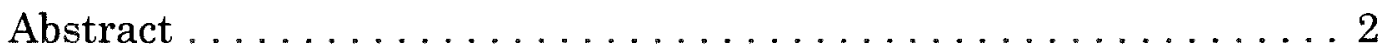

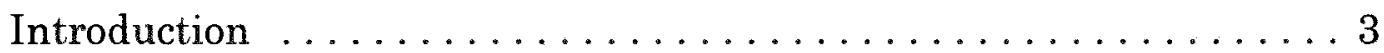

Materials and Methods ..................

Study Sites . . . . . . . . . . . . . . . . . . 8

Study Species . . . . . . . . . . . . . . . . . 9

Flower Phenology . . . . . . . . . . . . . . . . 9

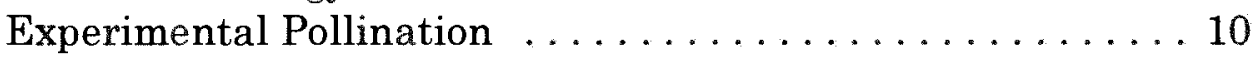

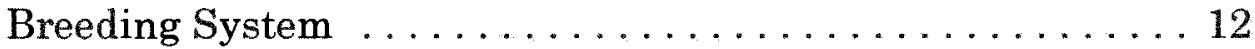

Results ........................ 13

Flowering Phenology $\ldots \ldots \ldots \ldots \ldots \ldots \ldots \ldots \ldots \ldots$

Flower Phases . . . . . . . . . . . . . . . . 14

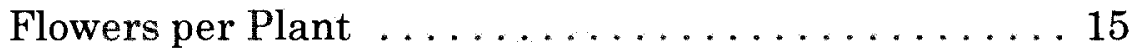

Seasonality of Flowering $\ldots \ldots \ldots \ldots \ldots \ldots \ldots \ldots$

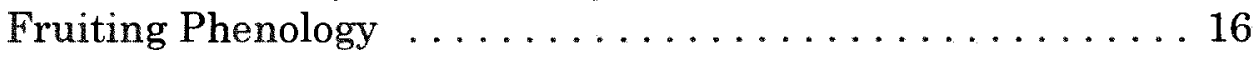

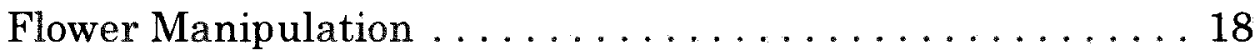

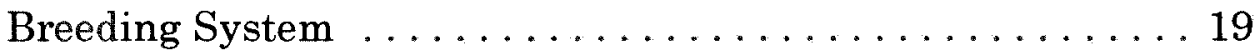

Discussion ............................. 19

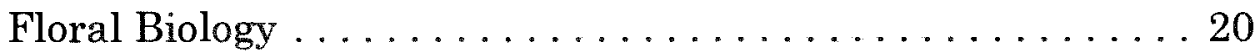

Flowers . . . . . . . . . . . . . . . . 20

Individual Plants . . . . . . . . . . . . . . 21

Population Patterns . . . . . . . . . . . . . . . 22

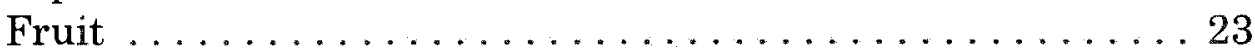

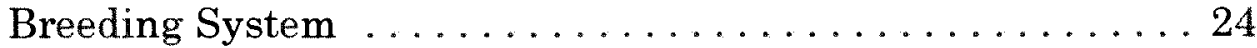

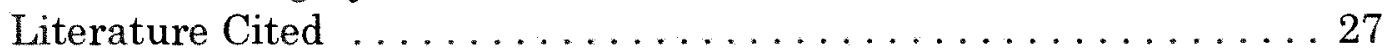

II: INSECT FAUNA ASSOCIATED WITH ASIMINA

(ANNONACEAE) FLOWERS. . . . . . . . . . . . . . 49

Abstract ............................ 50

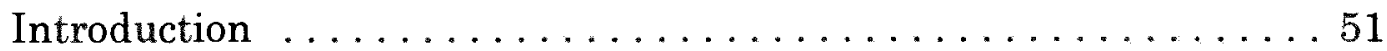

Materials and Methods .................... 58

Study Sites . . . . . . . . . . . . . . . . . 58

Asimina Species ..................... 58

Insect Methods . . . . . . . . . . . . . . . . . . 59

Statistical Analyses . . . . . . . . . . . . . . . 61

Results

Beetles ..........................61 61

Other Insects ..........................664 
Herbivores ........................65

Insects and Flowers .................666

Discussion ............................67 67

Asimina reticulata Beetle Pollinators . . . . . . . 69

Asimina tetramera Beetle Pollinators . . . . . . . . . 70

Other Insect Visitors . . . . . . . . . . . . . . 70

Asimina Flowering $\ldots \ldots \ldots \ldots \ldots \ldots \ldots \ldots \ldots \ldots \ldots \ldots$

Endemic and Rare Species $\ldots \ldots \ldots \ldots \ldots \ldots \ldots \ldots \ldots \ldots$

Herbivores .......................... 73

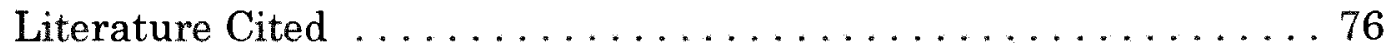

III: EFFECTS OF MANAGEMENT ON THE FOUR-PETAL

PAWPAW, ASIMINA TETRAMERA, AN ENDANGERED

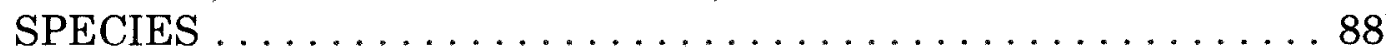

Abstract . . . . . . . . . . . . . . . . . . . . . . 89

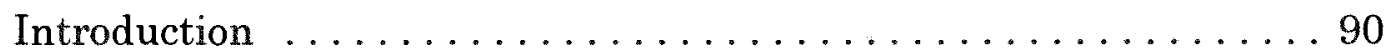

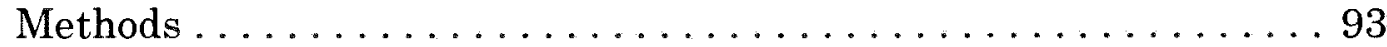

Study Site ...................... 93

Site Preparation . . . . . . . . . . . . . . . 96

Study Species . . . . . . . . . . . . . . . . 96

Results .............................97

Statistical Analysis . . . . . . . . . . . . . 96

Discussion . . . . . . . . . . . . . . . . . . . 101

Flowering Response to Fire . . . . . . . . . . . . 101

Flowering Response to Cutting . . . . . . . . . . . 102

Flowering in the Control . . . . . . . . . . . . . . . . 102

Effects of Season of Burn . . . . . . . . . . . 103

Fruit Response . . . . . . . . . . . . . . . . 104

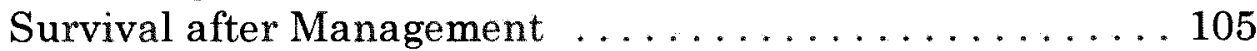

Literature Cited . . . . . . . . . . . . . . . . 107

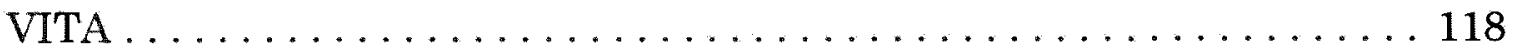


TABLE

PAGE

CHAPTER I

Table 1. Flower phases and duration in days (mean $\pm \mathrm{SD}$ ) that flowers remain in each phase for Asimina reticulata and $A$. tetramera at JDSP in $1995 \ldots \ldots \ldots . \ldots 33$

Table 2. Flower and fruit phenology of Asimina reticulata and $A$. tetramera in 1995 and $1996 \ldots \ldots \ldots \ldots \ldots \ldots$

Table 3. ANOVA for flower and fruit on 25 Asimina reticulata and 25 A. tetramera plants in 1995 and 1996 at JDSP and DRP . . . . . . . . . . . . . . . 35

Table 4. ANOVA for fruit-set for hand self-, cross-, and open-pollinated flowers in 1995 and 1996 at JDSP and DRP.

Table 5. Results of hand self-, cross-, and open-pollinations for Asimina reticulata and A. tetramera in 1995 and 1996

\section{CHAPTER II}

Table 1. Flower visitors to Asimina reticulata and $A$. tetramera in sand pine scrub habitat in 1994-1996 at JDSP in Martin County and DRP in Palm Beach County, Florida . . . . . . . . . . . . . . 81

Table 2 Insect Orders and Coleoptera families associated with Asimina reticulata and $A$. tetramera in sand pine scrub habitat in 1994-1996 at JDSP in Martin County and DRP in Palm Beach County, FL . . . . . . . 83 
CHAPTER III

Table 1 Percent Asimina tetramera flowering and setting fruit in four resource management areas and CONTROL from 1994 - 1996

Table 2. Summary of models for percent plants flowering in four treatment areas and CONTROL from 1994 -

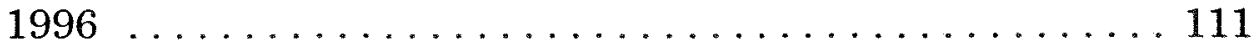

Table 3 Summary of models for percent plants fruiting in four treatment areas and CONTROL from 1994 -

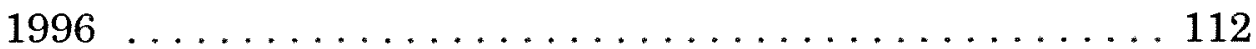


FIGURE

\section{CHAPTER I}

Figure 1. Locations of research sites in Martin and Palm Beach Counties ......................... 38

Figure 2A. Reproductive stems of Asimina reticulata showing flowers in phases $1-7 \ldots \ldots \ldots \ldots \ldots \ldots \ldots \ldots$

Figure 2B. Reproductive stems of Asimina tetramera showing

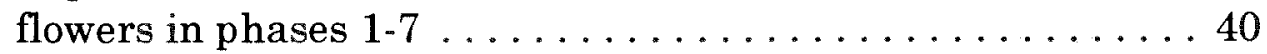

Figure 3A. Asimina reticulata flower phases $1-7 \ldots \ldots \ldots \ldots \ldots$

Figure 3B. Asimina tetramera flower phases $1-7 \ldots \ldots \ldots \ldots \ldots \ldots$

Figure 4. Mean (SE) number of (A) flowers and (B) fruit on 25 Asimina reticulata plants at JDSP and DRP in 1995 and 1996

Figure 5. Mean (SE) number of (A) flowers and (B) fruit on 25 Asimina tetramera plants at JDSP and DRP in 1995 and 1996

Figure 6. Flowering phenology for Asimina reticulata and $A$. tetramera at JDSP and DRP in (A) 1995 and (B) 1996

Figure 7. Fruiting phenology for Asimina reticulata and $A$. tetramera at JDSP and DRP in (A) 1995 and (B) 1996 
FIGURE

PAGE

Figure 8. The effects of three pollination treatments on Asimina reticulata and $A$. tetramera in 1995 and 1996

Figure 9. Index of inbreeding depression (ID) for Asimina reticulata and $A$. tetramera in 1995 and $1996 \ldots \ldots \ldots 4$

CHAPTER II

Figure 1. Open Asimina reticulata and A. tetramera flowers .......884

Figure 2. Insect visitor frequency to Asimina flowers during 1994 flowering season $\ldots \ldots \ldots \ldots \ldots \ldots \ldots$

Figure 3. Insect visitor and flower frequency to Asimina during 1995 flowering season $\ldots \ldots \ldots \ldots \ldots \ldots \ldots$

Figure 4 Insect visitor and flower frequency to Asimina

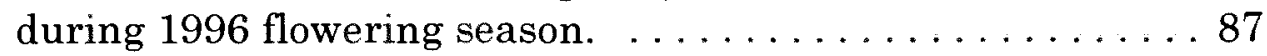

CHAPTER III

Figure 1. Research site at JDSP and location of management

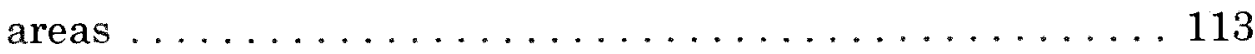

Figure 2. Seasonal flowering and fruiting phenology of Asimina tetramera in (A) population, (B) 1995 CONTROL and (C) 1996 CONTROL . . . . . . . . . . 114

Figure 3. 1996 flower and fruit phenology of Asimina tetramera in (A) BURN, (B) CUT\&BURN, (C) MULCHED, and (D) HAND-CUT . . . . . . . . . . 115 
FIGURE

PAGE

Figure 4 Flower and fruit phenology for two plants in the four treatments and CONTROL . . . . . . . . . . 116

Figure 5. Percent Asimina tetramera plants with (A) flowers and (B) fruit from $1994-1996$ at JDSP . . . . . . . . 117 
THE FLOWERING PHENOLOGY AND REPRODUCTIVE BIOLOGY OF TWO ENDEMIC FLORIDA PAWPAWS:

ASIMINA RETICULATA AND ASIMINA TETRAMERA 
The flowering phenology and reproductive biology

of two endemic Florida pawpaws:

Asimina reticulata and Asimina tetramera

\begin{abstract}
I studied the phenology and breeding systems of two endemic Florida
\end{abstract} pawpaws. Asimina reticulata is widespread in peninsular Florida and Asimina tetramera, a federally endangered species, is limited to Martin and Palm Beach Counties on the Atlantic Coastal Ridge. The study was conducted in two sand pine scrub sites that contained the largest extant populations of Asimina tetramera. Although flowering seasons overlap, $A$. reticulata plants flower for a shorter duration in early spring, and $A$. tetramera flower in late spring and summer. Both species are strongly protogynous. Pollination experiments show that neither species is autogamous; the primary breeding system is outcrossing, although low levels of geitonogamous pollination occur in open, mature scrub habitats or the first year following fire. High levels of inbreeding depression occurred in both species at both sites but inbreeding depression was relaxed in Asimina tetramera the first year post-fire. Fruit set in mature habitats may be pollinator limited.

Key words: Asimina reticulata, Asimina tetramera, endangered species, sand pine scrub, phenology, pollination, outcrossing 


\section{INTRODUCTION}

Many plant taxa are restricted to Florida scrub communities (Austin et al. 1987, Christman and Judd 1990, Myers 1990, USFWS 1996). Forty of the 300 or more scrub species known to occur (Richardson 1989) are listed as endangered or potentially endangered by the State of Florida (Wood 1997). Many of these species occur on the Central Florida Ridge, an ancient shoreline. The scrub habitats on this ridge are often referred to as ancient scrubs persisting since early Pleistocene (Christman and Judd 1990), in comparison to scrub on the Atlantic Coastal Ridge, a dune system of more recent geological origin. Studies of endemic and listed species in Central Florida focus on the effects of fire on life histories (Hawkes and Menges 1995, Lambert and Menges 1996, Menges and Kimmich 1996) or demography (Hartnett and Richardson 1989, Ostertag and Menges 1994, Hawkes and Menges 1996, Menges and Hawkes in press). Most of these investigations examine short lived perennial species of small stature that prefer open areas within mature scrub (Hawkes and Menges 1995, Menges and Hawkes in press, Young and Menges in press); few studies examine large shrubs or long lived plants.

Although several listed species occur on both the Central Florida Ridge and the Atlantic Coastal Ridge, Asimina tetramera Small is one of the few federally listed species that occurs only on the Atlantic Coastal Ridge (Austin and Tatje 1979). Asimina tetramera grows only in Martin and Palm Beach 
Counties. Asimina reticulata Chapman, another endemic, is sympatric with A. tetramera in coastal dune sand pine scrub habitat, but it also inhabits slash pine, long-leaf pine/saw palmetto flatwoods, and seasonally wet pine savannas (Godfrey and Wooten 1981). In 1979, A. tetramera was thought to be extirpated from Palm Beach County and approximately 100 plants were known to exist in Martin County (Austin and Tatje 1979). U.S. Fish and Wildlife Service (USFWS) listed Asimina tetramera as endangered in 1988 because of its rarity and the loss of sand pine scrub habitat in rapidly expanding urban areas. Florida Natural Areas Inventory (Farnsworth 1988) reported $742 \mathrm{~A}$. tetramera plants in 16 scrub sites in a radius of $30 \mathrm{~km}$ on the Atlantic Coastal Ridge. The two largest populations were in Jonathan Dickinson State Park (JDSP) (157 plants) and 224 plants in a proposed park, Diamondhead Radnor Park (DRP).

Members of the Annonaceae exhibit various types of dichogamy (Armstrong and Marsh 1997). Flowers in this large (> 2,000 species), mostly tropical family are commonly self-compatible and protogynous, often with a neutral phase between male and female phases (Endress 1994). Receptive stigmas are secretory and may abscise at the end of the female phase (Endress 1994). In many genera, excised stamens remain attached to each other and the pollen tetrads adhere by viscin threads for better pollen exposure (Endress 1994). Beetle pollination is typical of many Annonaceae and the pollinator is often trapped inside the flowers (Endress 1994). 
Although species in the Annonaceae are primarily tropical, two genera, Asimina and Deeringothamnus, are temperate (Kral 1960). Eight Asimina species are known from Florida, with six primarily limited to Florida (Wunderlin 1998). Norman et al. (1992) studied the reproductive biology of A. parviflora and $A$. obovata, and Norman and Clayton (1986) investigated $A$. pygmaea in northern and central Florida. Willson and Schemske (1980) examined floral display and limits to fruit production in Asimina triloba. All of these Asimina species are hermaphroditic and protogynous.

Flower production patterns vary in closely related species and within populations (Gentry 1974, Augspurger 1983, Primack 1987, Newstrom and Frankie 1994). Many tropical and temperate plants produce flowers at a distinct time of year, lasting from a few weeks to months with all individuals of a species blooming during a general time span (Gentry 1974, Primack 1987). Gentry (1974) classified tropical Bignonaceae into five classes, but temperate patterns neither change as much over geographic ranges nor are they as complex as tropical patterns (Newstrom and Frankie 1994).

Individual plants in a population induce flowering at different times, produce varying number of flowers, and remain in flower for unspecified durations (Augspurger 1983). Differences in flowering time may be influenced by genetically controlled factors or environmental factors of temperature, day-length, and rainfall (Dafni 1992, Gentry 1974). The number of flowers is determined by the resources available and there may be 
a trade-off between producing numerous large flowers and maturation of developing fruit (Primack 1987). The duration of flowering or longevity of individual flowers varies among species, families, habitats, seasons, and breeding systems (Dafni 1992). In bisexual dichogamous flowers, the first reproductive phase is the longest. Asynchronous flowering on an individual plant reduces the frequency of geitonogamy and promotes outcrossing (Dafni 1992).

Variations in flowering time within natural populations are related to the reproductive success of the plants. Augspurger (1983) showed that mass flowering in a tropical shrub increased visitation rates of social bees. Studies of the variation of flowering times and reproductive capacity in New Zealand montane shrub and herb species showed a progression of flowering throughout the growing season with one species coming into flower as another declines (Primack 1980). Many tree species in Central America time flower and fruit with the dry season when the plants are leafless and to capitalize on available pollinators and seed dispersers (Janzen 1967).

Individual plants within a population do not always have the same flowering pattern. A plant's reproductive success may be determined by the degree of flowering synchrony with other individuals in the population (Janzen 1967, Gentry 1974, Augspurger 1983, Gómez 1993). Flowering synchrony was defined by Augspurger (1983) as the number of days that flowering of an individual overlaps with the flowering of every other plant in 
the sample.

Closely related species in tropical and temperate areas may flower at different times of the year, as an isolating mechanism for speciation and a means of partitioning pollinator resources (Gentry 1974, Newstrom and Frankie 1994). Some authors have suggested that competition for pollinators may influence displacement of flowering times (Waser 1983a, Waser 1983b). Flowering peaks in six sympatric Central American Bignonaceae occur in different months, providing an example of separation in time (Gentry 1974). The timing of flowering and fruiting affects critical life history stages and directly influences germination and recruitment (Bowers and Dimmit 1994). The range of a plant species is also affected by the timing of seed dispersal. The purpose of this study was to describe the flowering and fruiting phenology and to determine the breeding systems of two Florida endemic species, Asimina reticulata and A. tetramera, in sand pine scrub habitat. I examined flowering and fruit-set on three levels: flower, plant, and population. I conducted breeding system experiments in the field to determine outcrossing rates based on fruit-set. My hypothesis was that differences in phenology and mating systems contribute to the rarity of Asimina tetramera compared with A. reticulata. 


\section{MATERIALS AND METHODS}

\section{Study Sites}

The two study sites support the largest extant populations of Asimina tetramera. These sand pine scrub habitats are on the Atlantic Coastal Ridge within one $\mathrm{km}$ of the Atlantic Ocean (Fig. 1). The sand pine scrub habitat on relict dunes is characterized by Entisols, excessively drained, nutrient poor sands in the Paola-St. Lucie soil associations (Myers 1990). The largest contiguous parcel ( 853 hectares) of sand pine scrub on the southeastern Atlantic Coastal Ridge is in Jonathan Dickinson State Park (JDSP). It is located in the center of the $65 \mathrm{~km}$ range of Asimina tetramera and has the largest population (157 plants) of the six sites in Martin County. The Diamondhead Radnor Park (DRP), $22 \mathrm{~km}$ south of JDSP, is an undeveloped tract and has the largest population of A. tetramera (224 plants) of the 10 Palm Beach County sites. The individual populations are limited to small areas ( $>4$ hectares) at elevations between 3 and 5 meters (mean sea level) within larger scrub habitats. The scrub habitat ( 24 hectares) is open with large sandy areas and the sand pines are concentrated in clusters $(20 \%$ cover) at DRP in contrast to the JDSP site, which has few open sandy areas and an almost continuous canopy of sand pines (80\%). Both sites have a history of disturbance in the early 1940's although no records of recent fire exist for either site and no evidence of burning was noted. 


\section{Study Species}

Asimina species are perennial shrubs with one to many branched shoots arising from a deep taproot or below-ground crown (Kral 1960). Leaves are deciduous, alternate and two-ranked on the stems, but the leaf arrangement is spiral on Asimina reticulata (Fig. 2A) in contrast to the leaves of $A$. tetramera (Fig. 2B) that are distichous. Asimina reticulata grows to 1.5 meters tall with stiff, sometimes branched shoots and A. tetramera may reach four meters. The hermaphroditic flowers exhibit protogyny. Flowers of both species are radially symmetrical with one to 3 flowers per node and commonly have three sepals, three inner petals and three outer petals. The inner petals are smaller than the inner petals. One to nine carpels surmount the torus in the center of the stamens and produce a sticky exudate when receptive (Kral 1960). Numerous stamens connect to the raised torus and mature after the carpels. Pollen tetrads remain attached to the floral base by viscin threads (Endress 1994).

\section{Flower Phenology}

I investigated flowering and fruiting phenology for single flowers, individual plants, and the population. By using a random number table and traversing the habitat, I selected 80 Asimina reticulata and A. tetramera plants from each population: 10 for individual flower observations, 25 for flower counts, and 25 for floral manipulations. The same plants were used in 1995 and 1996 to detect annual variation. 
For single flowers, I observed flower emergence and development on ten plants of each Asimina species in 1995 to determine stigmatic receptivity and duration of flowering. I marked two or three unopened flower buds on each plant and followed them daily from bud expansion through fruit initiation to determine the timing of flower phases. Flowers were assigned to six phases from bud to fruit-set based on perianth size, color, and stage of reproductive maturity. Stigma receptivity and time of anther dehiscence were determined by visual observation of flowers every hour in the morning during anthesis. The stigma was considered receptive when the surface glistened and stamen maturity was determined by anther dehiscence.

I monitored 25 plants weekly and recorded the number of flowers and fruit on each plant during the flowering and fruiting season. I plotted the number of open flowers per week from flower initiation in January until flower termination and monitored fruit until ripe. Marked fruit that remained on plants for six weeks were considered mature, as most fruit abortion occurred during the first three weeks after pollination. Although many flowers have multiple carpels with each carpel forming a distinct fruit, I considered a single fruit for each flower regardless of the number of carpels that developed per flower. The reproductive effort of the flower was underestimated using this method.

\section{Experimental Pollination}

I conducted controlled hand pollinations in the field on 25 Asimina 
reticulata plants on each site and 25 A. tetramera plants at DRP. However, for $A$. tetramera at JDSP only 20 of the 25 plants flowered in 1995 and only 12 plants were included in the study after a prescribed 1996 May burn. All treatments were performed on each plant so that comparisons could be made for family structured data as described by Johnston and Schoen (1994). For all treatments except open-pollination, polyester organza bags were placed over branches containing several unopened flowers and tied with a cloth covered wire to preclude visitors. Because $A$. tetramera have few flowers, five to seven branches on each plant were bagged. After seven to 10 days, pollen was collected from bagged flowers and applied to receptive flowers on either the same plant for self-pollinations or different plants for cross-pollinations. I removed bags to pollinate the flowers and replaced them for two more days as bags left on open flowers for more than three days interfered with carpel development. Preliminary pollination experiments showed that pollen tubes reached the ovules within six hours of pollination.

I conducted five flower treatments in 1995: 1) autogamy, or automatic self-pollination, allowing the flower to self-pollinate with no treatment except bagging, 2) geitonogamy, or self-pollination, using pollen from a flower on the same plant, 3) xenogamy, or cross-pollination, using pollen from a flower of another plant, 4) apomixis, or seed production without fertilization, by removing stigmas and bagging flowers, leaving the bag on until carpels mature, and 5) open-pollination by allowing natural insect visitors to 
pollinate the flowers.

Autogamy and apomixis treatments produced no fruit in 1995 , so these treatments were not repeated in 1996. The other three treatments (hand self-pollination, hand cross-pollination and open-pollination) were repeated in 1996 to compare year to year variability. To test for differences in the proportion of flowers per plant that set fruit for the three treatments, I conducted a three-way ANOVA using year, site, and treatment for each species. The data were transformed using arcsine square root angular transformations for proportions (Sokal and Rohlf 1981).

Hand pollination for interspecific crosses were also conducted between A. reticulata and $A$. tetramera when pollen was available from one species and a recipient flower of the other species was receptive. So few flowers were available from the two Asimina species that the data were not analyzed.

\section{Breeding System}

I used the index of self-incompatibility (ISI) described by Ruiz and Arroyo (1978) to determine the breeding system. The ISI was calculated as the mean proportion of flowers that set fruit from hand self-pollinations divided by the mean proportion of flowers that set fruit from hand crosspollinations. Plants determined to be self-incompatible have scores ranging from $0.00-0.2$, partial self-incompatibility ranges from $0.2-1.0$ and selfcompatibility scores are greater than 1.0 (Ruiz and Arroyo 1978).

Inbreeding depression was calculated by comparing self- and cross- 
fitness from the number of fruit obtained from individual plants and is a measurement of a single aspect of the life history stage. Family inbreeding depression was calculated as $\delta=1-\mathrm{w}_{\mathrm{s}} / \mathrm{w}_{\mathrm{o}}$, where $\mathrm{w}_{\mathrm{s}} / \mathrm{w}_{\mathrm{o}}$ (mean fitness) is the product of the mean relative fitness for fruit-set (Husband and Schemske 1996). This method is referred to as family structured data (Johnston and Schoen 1994) and allows an independent pairwise comparison between selfand out-crossed offspring.

\section{RESULTS}

\section{Flowering Phenology}

Flowering commencement is different for the two Asimina species. In early February, Asimina reticulata buds break dormancy on old wood and flower maturation is basipetal, from the tip of the stem toward the base (Fig. 2A). However, after several flowers open, other flowers open simultaneously. In contrast, $A$. tetramera plants break dormancy in early April from the tips of the stems, producing shoots, leaves and flowers in the axils of the developing leaves (Fig. 3A). Flowers open acropetally, from the base of the stem toward the developing tip, on terminal shoots and on plants with single stems. Five or more flowers develop per stem and all flower phases (from bud to setting fruit) may be present on a shoot at the same time. On plants with lateral branches, three to five flowers may mature simultaneously. In both species, a single flower usually is produced in the leaf axil, but two or 
three may emerge if the stem has been broken or damaged by fire or cutting.

\section{Flower Phases}

I assigned six categories to flower phases from bud expansion, Phase 1, through fruit initiation, Phase 7 (Figs. 3A, B). Except for bud development, the sequence of events for flower opening was similar in both species. Asimina reticulata buds (Phase 1) from the previous year break dormancy in less time ( $\bar{x}=4.2$ days) than $A$. tetramera buds develop from the leaf axils $(\bar{x}$ $=11.8$ days) (Table 1). Phase 2 , petal elongation to twice the length of the sepals, is similar for both species. In Phase 3, outer petals elongate beyond the inner petals and move apart at the tips, providing an opening for insects into the maturing carpels of the flowers. Flowers become functionally pistillate in Phase 4 which lasts two days. Stigmas glisten and the outer petals begin to change color from green to white in Phase 5, and the corrugated tissue thickens and turns maroon. The inner petals become dark maroon, or on some flowers, deep yellow, and a strong yeasty odor is produced in the evening during the second day of Phase 5.

As flowers become functionally staminate in Phase 6, the stigma lobes become non-receptive and abscise easily. On sunny days, anthers release pollen between 8 am and noon; on rainy or cloudy days the pollen is released in mid-to late-afternoon. Abscising stamens remain attached to the torus by extended spiral thickenings (Okada 1990). The pollen tetrads attach to each other and to the abscising stamens by viscin threads that facilitate pollen 
adherence to flower visitors. Petals fall from the flowers the second day after pollen release. Flowers that were not pollinated abscise in 3-6 days. In pollinated flowers, the torus enlarges as carpels mature. Developing fruit are assigned to Phase 7.

\section{Flowers per Plant}

For both species, more flowers were produced per plant at DRP than at JDSP in both years (Table 2). The data were analyzed separately for each species using ANOVA to test the difference between the number of open flowers per plant (square root transformed) for the two sites and the two years. There was a significant interaction effect between years and site for A. reticulata (Table 3A). Significantly more flowers per plant $\left(\mathrm{F}_{1,96}=11.44\right.$, $\mathrm{p}<0.001)$ were produced at DRP in 1996 than in 1995 or at JDSP in either year (Fig. 4A). For A. tetramera, the main effect for site was significant $\left(F_{1.96}\right.$ $=18.07, \mathrm{p}<0.001$ ), as more flowers per plant were produced at DRP in both 1995 and 1996 than at JDSP for both years (Fig. 5A).

\section{Seasonality of Flowering}

Flower timing and duration varied in the 25 plants from 1995 to 1996 for both species, although there were similar trends (Table 2A). In 1995 at DRP, two A. reticulata plants flowered in mid-January, stopped, and then resumed in mid-February when the remaining plants at both sites bloomed (Figs. 6A, B ). Peak flowering was a week later at JDSP than DRP for both

years. Peak flowering in 1995 occurred the second and third weeks in March 
when $44 \%$ plants at JDSP and $80 \%$ of the plants at DRP were in flower. In 1996 peak flowering was the second and third week when $96 \%$ of the plants at JDSP and all 25 plants at DRP were in flower. Flowering stopped abruptly in mid-April at both sites. Asimina reticulata at DRP flowered for 13 weeks, 4 weeks longer than at JDSP.

Asimina tetramera initiated flowering toward the end of March when A. reticulata stopped flowering (Figs. 6A, B ). Flowering times for the two species overlapped for two weeks, but few flowers were on plants of either species at that time. Inter-specific pollination is therefore possible. Asimina tetramera peak flowering occurred the second week in May at DRP when $68 \%$ of the plants were in flower in 1995 and $84 \%$ in 1996. At JDSP, peak flowering occurred during the fifth week of flowering, but only $52 \%$ of the plants in 1995 and $32 \%$ in 1996 flowered at one time. Asimina tetramera at JDSP remained in flower 7-8 weeks longer into the season than DRP plants during both years of the study.

\section{Fruiting Phenology}

Not all plants that flowered set fruit. Between $50 \%$ and $92 \%$ of the plants set fruit, and both species at DRP set more fruit per plant $(\bar{x}>3$ fruit/plant) than at JDSP ( $\bar{x}<2$ fruit/plant) (Table $2 B)$. Both species on both sites produced more fruit in 1995 than in 1996. One $A$. tetramera plant at DRP in 1995 set 30 fruit, compared with six fruit on an A. reticulata plant at JDSP. 
Fruit retention varied significantly (Table 1, Phase 7). Ripening times may also differ for fruit on the same plant: however, multiple carpels from the same flower generally ripened simultaneously. Late season fruit ripened in less time than early season fruit. Fruit remained on plants longer at DRP than at JDSP (Table 2B). In 1996, fruit remained on individual plants longer than in 1995 , with the exception of $A$. reticulata at JDSP. Fruiting duration was less in 1996 at JDSP, as the plants were cut or burned before all fruit ripened because of prescribed management.

The two sites and two years were analyzed separately for each species using a two-way ANOVA to test differences between the mean number of fruit per plant at each site (Table 3B). The main effect, site, was significant for $A$. reticulata for mean number of fruit (Fig. 4B). For A. tetramera the main effect, site, was also significant $\left(\mathrm{F}_{1,96}=20.56, \mathrm{p}<0.001\right)$.

Fruiting seasonality also varied. Asimina reticulata fruit remained on plants in the population for a maximum of 12 weeks at JDSP and DRP in 1995 , to a maximum of 17 weeks at DRP in 1996 . The average fruit duration for the population was 12.5 weeks in 1996 at JDSP (Table 2B). The high peaks on Figs. 6 and 7 are indicative of initial fruit-set. However, most fruit abortion occurs within the first 4 weeks after pollination, and the curves level off (Figs. 7A, B).

The percent of flowers setting fruit in A. reticulata was higher at JDSP and DRP in $1995(4.1 \%$ and $4.9 \%)$ than in $1996(3.2 \%$ and $1.2 \%)$. The ratio of 
fruit to flowers is expressed as a percentage in Table 2C. Plants that

flowered and did not produce fruit were not included. This ratio provided an estimation of fruit production for the population. In A. tetramera the highest fruit-set per plant in 1995 (5.7\%) was considerably less than the highest fruit-set at DRP (10.8\%) in 1995.

\section{Flower Manipulation}

Data for flower manipulations were analyzed separately with arcsine transformed data for $A$. reticulata and $A$. tetramera using three-way ANOVA. In $A$. reticulata, a significant difference (Table $3 \mathrm{~A}$ ) was found in the proportion of flowers setting fruit between years $\left(F_{1,288}=56.96, p<0.001\right)$, and among the three pollination treatments $\left(\mathrm{F}_{1,288}=70.36, \mathrm{p}<0.001\right)$. At JDSP and DRP for both years, there was no significant difference between the mean proportion of flowers setting fruit for the self- and openpollinations. However, for both sites and both years, cross-pollinations resulted in a significantly higher mean proportion of flowers setting fruit than either the self- or open-pollinations (Fig. 8A).

In $A$. tetramera a two-way treatment interaction was significant $\left(\mathrm{F}_{1,234}\right.$ $=3.04, p<0.001)$, and a two-way interaction was significant between the proportion of flowers setting fruit at the two sites and three pollination treatments $\left(\mathrm{F}_{1,234}=9.07, \mathrm{p}<0.001\right)$. At DRP, the mean proportion of flowers setting fruit was significantly higher for cross-pollination treatments in both years than for both self- and cross-pollinations. The mean proportion of 
flowers for cross-pollination at DRP was also significantly higher across all three treatments at JDSP in 1995 and for open-pollinations at JDSP in 1996. However, the mean proportion of flowers setting fruit for cross-pollinations at DRP were not significantly different than self- or cross-pollinations at JDSP in 1996. This interaction between site by treatments may be attributed to changing conditions in the burned scrub and may also be related to the reduced number of plants (Fig. 8B).

\section{Breeding System}

Low fruit-set from self-pollinations relative to cross-pollinations are responsible for the low calculated values for self-incompatibility indices (ISI) in both species at both sites. Lower ISI values were observed in 1995 for both species. Exceptions were $A$. reticulata in $1996(\mathrm{ISI}=0.25)$ and $A$. tetramera at JDSP $(\mathrm{ISI}=1.33)$ and DRP $(\mathrm{ISI}=0.5)$ in $1996($ Table 5).

\section{DISCUSSION}

Complex factors are involved in plant rarity (Schemske, et al. 1994, Drury 1980, Stebbins 1980). Rare plants differ from common ones in several aspects of their reproductive biology although the differences are seldom absolute (Drury 1980, Rabinowitz 1981, Kunin and Shmida 1997). Differences in abundance may include diversity of mating systems, reliance on animals for pollen, and seed dispersal. Dense populations have greater reproductive success than sparse populations, especially if they are self- 
incompatible. Large populations are rarely pollinator limited, but generalist pollinators may bring inappropriate pollen to small populations (Harper 1979). Rare self-incompatible plants that depend on floral constancy of insect visitors may be vulnerable to extinction if their specialized pollinators are themselves rare (Kunin and Shmida 1997).

\section{Floral Biology}

Flower phases are comparable between $A$. reticulata and $A$. tetramera, with the exception of the initial bud development phase. Autogamy, or selfpollination, was not observed and may be extremely rare in both $A$. reticulata and $A$. tetramera, because the stigma is no longer receptive at the time of pollen release. These timings differ from studies of $A$. triloba (Willson and Schemske 1980) and $A$. parviflora (Norman et al. 1992) that have an overlap in male and female phases. The first flowers of the season in both species rarely set fruit (personal observation) and may function to attract pollinators and serve as pollen donors (Willson and Schemske 1980). Both Asimina species are pollinated by beetles, although by different suites of species, which may be related to life history stages of the insects, seasonal environmental changes in the habitat (Chapter 2), or differences in floral reward and odor.

\section{Flowers}

Although both species flower in the spring dry season, A. reticulata flowers earlier, for a shorter duration, and produces more flowers per plant 
than A. tetramera (Table 2A). Plants with large floral displays attract more insect pollinators and abundant flowers emit stronger odors thus increasing the attraction to beetles (Endress 1994). Because Asimina flowers are protogynous and pistillate flowers remain receptive for 4-6 days, more female flowers are available than male flowers and the likelihood of a pollinator entering a female flower increases. A disadvantage to having abundant flowers is an increased probability for geitonogamy as pollinators move pollen to flowers on the same plant.

\section{Individual Plants}

Asimina reticulata plants in flower are more visible to insects than $A$. tetramera plants because flowering occurs on leafless stems. Flowers open before leaves are produced and the abundant flowers are conspicuous in early spring when few other plants are flowering, much like those in Costa Rican dry forests (Janzen 1967). The flowering duration for individual plants is shorter for A. reticulata and late flowering plants set fewer fruit. There is a general tendency in $A$. reticulata to synchronize flowering among plants, increasing the plants visibility (Fig. 6).

Fewer flowers are in the same phase on A. tetramera because of the difference in flower development timing, resulting in increased outcrossing (Table 5). Unlike $A$. reticulata, individual plants tend to be asynchronous, initiating flowering at different times during the natural flowering season, further contributing to cross-pollination (Fig. 6). For some plants in the 
population, flowering overlap is minimal. Older plants, with small diameter stems, tend to produce abundant flowers but do not set fruit. These plants serve as pollen donors to the population. Willson and Schemske (1980) also noted this phenomenon in A. triloba.

\section{Population Patterns}

Flowering in $A$. reticulata is comparable to the "big bang" strategy described by Gentry (1974) although the population flowering duration is several weeks rather than a few days (Fig. 7). While not as dramatic as some of the bee-pollinated Bignonaceae, $A$. reticulata individuals synchronized flowering in the fourth or fifth week of flowering (Fig. 6). In 1996, an abundant flowering year, most $A$. reticulata plants (96\%) at JDSP and $100 \%$ at DRP were in flower during the same week. This may be important in geitonogamous pollen transfer as many pollinators move downwards on the basipetal inflorescence. Plant with many flowers on a stem are equivalent to vertical inflorescence and contribute to increased geitonogamous pollination (Dafni 1992).

Asimina tetramera produces fewer flowers than $A$. reticulata and the flowering season is less predictable (Table 2A). The flowering time of individual $A$. tetramera is spread out over a longer duration and peak flowering is not as dramatic as $A$. reticulata. Flowering patterns are similar to the generalized "cornucopia" pattern of Gentry (1974), with peak flowering for several weeks and then reduced flowering in later months (Fig. 6). This 
flowering pattern attracts a diverse spectrum of pollinators over an extended season.

Kral (1960) indicated that most pawpaws hybridize readily, but he found no evidence of hybridization between $A$. tetramera and A. reticulata. Norman and Clayton (1986) noted hybridization between $A$. obovata and $A$. pygmaea, supporting Kral's observations. Intraspecific hand-pollinations between $A$. tetramera and $A$. reticulata in my study were successful, and germinated seedlings are being monitored. Natural pollinations are possible between the two species and Asimina reticulata is more likely the pollen donor due to phenological precedence.

\section{Fruit}

Individual plants showed wide variation in total number of fruit, although many flowers were produced and pollinated (Table $2 \mathrm{~B}$ ). The percent of fruit per flower was low, especially in $A$. reticulata with the large floral display. Willson and Schemske (1980) found that higher fruit production occurred on stems with higher light intensities perhaps associated with the higher photosynthetic rates. Fruit production ranges for $A$.

reticulata $(1.2-4.9 \%)$ and $A$. tetramera $(2.3-10.8 \%)$ were similar to $A$. obovata and $A$. pygmaea (8\%) (Norman and Clayton 1986) and $A$. parviflora (3.8\%) (Norman et al. 1992). Fruit production for these species was considerably higher than the $0.45 \%$ for $A$. triloba, the widespread tree species in the eastern U.S (Willson and Schemske 1980). These patterns of fruiting may 
represent a natural range of fruit that the species can support with the available environmental resources and pollinator availability. The lower fruit-set in the mature habitat or for individuals in closed canopy situations may reflect only cross-pollinated flowers and pollinators may be limited in dense scrub habitat (Table 5).

\section{Breeding System}

Annonaceae are primarily self-compatible (Endress 1980, Gottsberger 1990), although in many species mechanisms to avoid inbreeding are absent (Gottsberger 1989). Pollination experiments show that neither A. reticulata or $A$. tetramera is autogamous and the primary breeding mechanism is xenogamy or outcrossing. Other species of Asimina are also primarily outcrossers, but set low numbers of fruit by geitonogamous pollination (Willson and Schemske 1980, Norman and Clayton 1986, Norman et al. 1992).

For both sites, open-pollination produced more fruit than selfpollination thus indicating that outcrossing was the predominant breeding mechanism. The higher number of flowers at DRP resulted in increased opportunity for geitonogamy, and the ratio of self- to cross-pollinations should be high. If deleterious effects caused by selfing have been purged from the population, then selfing may occur without noticeable ill effects. The higher proportions of flowers selfing at DRP in 1996 may be attributed to increased flowering in the open, sunny habitat. Self-pollination in 
predominantly outcrossing species generally results in inbreeding depression (Endress 1994). Since both Asimina species are outcrossers, the high values obtained for inbreeding depression were expected (Fig. 8).

Pollination experiments at JDSP in 1996 with $A$. tetramera were conducted during the summer after a prescribed burn. The results showed increased flowering associated with the post-fire environment. Vigorous shoots provided larger stems for the increased flowering and fruit development. The increase in fruit-set with selfing compared to outcrossing (Table 5) resulted in the high index of self-incompatibility perhaps from a relaxation of inbreeding depression in response to the excellent conditions for fruit production.

Asimina tetramera is a narrow endemic and fits the definition of classic rarity as defined by Rabinowitz (1981). The present distribution of Asimina tetramera in Palm Beach and Martin County is smaller than described by Kral (1960). Although fewer flowers per plant are produced by A. tetramera (Table 2), fruit production was generally higher for A. tetramera at both sites (Table 2C). Asimina tetramera population sizes probably did not exceed 200-250 plants per site. Considering that $96 \%$ of the scrub has been destroyed by development in Palm Beach County (Iverson and Austin 1986), the total number of $A$. tetramera plants was not large at any time in recent history.

The relationship between reproductive biology and rarity is poorly 
understood and many characteristics of the reproductive systems may be related (Weller 1994). Studies of breeding systems, mating success and population sizes in rare species contribute valuable information on causes of rarity for conservation (Sipes and Tepedino 1995, Fischer and Matthies 1997, Morán-Palma and Snow 1997). Based on the results of this study, differences between $A$. reticulata and $A$ tetramera in flowering and fruiting phenology and breeding systems appear to be site related and are attributed to environmental conditions that exist on those sites. No one aspect of the phenology or mating system obviously contributes to the rarity of $A$. tetramera compared with $A$. reticulata. The differences in the self- and crosspollination at JDSP after prescribed burning indicate that $A$. tetramera has the capacity to produce fruit through geitonogamous pollination under different environmental conditions. These results should be viewed with caution as a reproductive response at one site may not be transferable to another site and similar management applications should be applied to DRP or other sites before broad conclusions are made. 


\section{LITERATURE CITED}

Armstrong, J. E. and D. Marsh. 1997. Floral herbivory, floral phenology, visitation rate, and fruit-set in Anaxagorea crassipetala (Annonaceae), a lowland rain forest tree of Costa Rica. Journal of the Torrey Botanical Society, 124(3):228-235.

Augspurger, C. K. 1983. Phenology, flowering synchrony, and fruit-set of six neotropical shrubs. Biotropica 15(4):257-267.

Austin, D. F. and B. E. Tatje. 1979. Endangered Four-petal Pawpaw. In Rare and Endangered Biota of Florida, Volume 5 Plants. D. B. Ward (ed.), pp. 5-6. University Presses of Florida. Gainesville, FL.

Austin, D. F, F. Posin and J. Burch. 1987. Scrub species patterns on the Atlantic Coastal Ridge, FL. Journal of Coastal Research 3(4) :491-498.

Bowers, J. E. and M. A. Dimmitt. 1994. Flowering phenology of six woody plants in the northern Sonoran desert. Bulletin of the Torrey Botanical Club 121(3):215-229.

Christman, S. P. and W. Judd. 1990. Notes on plants endemic to Florida scrub. Florida Scientist 53(1):52-73.

Dafni, A. 1992. Pollination Ecology: A Practical Approach. D. Rickwood and B. D. Hames (eds.). Oxford University Press. Oxford.

Drury, W. H. 1980. Rare species of plants. Rhodora 2:3-48.

Endress, P. K. 1994. Diversity and evolutionary biology of tropical flowers. Cambridge University Press. 
Farnsworth S. 1988. Four-petal pawpaw survey. Florida Natural Areas Inventory, The Nature Conservancy, and The Florida Department of Natural Resources.

Fischer, M. and D. Matthies. 1997. Mating structure and inbreeding and outbreeding depression in the rare plant Gentianella germanica (Gentianaceae). American Journal of Botany 84(12):1685-1692.

Gentry, A. H. Gentry, Alwyn H. 1974. Flowering phenology and diversity in the tropical Bignonaceae. Biotropica 6:64-68.

Godfrey, R. K. and J. R. Wooten. 1981. Aquatic and Wetland Plants of Southeastern United States. Dicotyledons. University of Georgia Press. Athens.

Gómez, J. E. 1993. Phenotypic selection on flowering synchrony in a high mountain plant, Hormathophylla spinosa (Cruciferae). Journal of Ecology 605-613.

Gottsberger, G. 1989. Beetle pollination and flower rhythm of Annona spp. (Annonaceae) in Brazil. Plant Systematics and Evolution 167:165-187.

Gottsberger, G. 1990. Flowers and beetles in the south American tropics. Botanica Acta 103(4):360-365.

Harper, K. T. 1979. Some reproductive and life history characteristics of rare plants and implications of management. Great Basins Naturalist Memoirs 3:129-137.

Hartnett, D. C. and D. R. Richardson. 1989. Population biology of Bonamia grandiflora (Convolvulaceae): effects of fire on plant and seed bank dynamics. American Journal of Botany 76(3):361-369. 
Hawkes, C. V. and E. S. Menges. 1995. Density and seed production of a Florida endemic. Polygonella basiramia, in relation to time since fire and open sand. American Midland Naturalist 133:138-148.

Hawkes, C. V. and E. S. Menges. 1996. The relationship between open space and fire for species in a xeric Florida shrubland. Bulletin of the Torrey Botanical Club 123(2):81-92.

Husband B. C., and D. W. Schemske. 1996. Evolution and the magnitude and timing or inbreeding depression in plants. Evolution 50(1):54-70.

Iverson, Grace B. and Daniel F. Austin. 1986. Inventory of Native Ecosystems in Palm Beach County Phase III Report. Location and Evaluation of sites for possible preservation as Wilderness Island Preserves. Report to Palm Beach County.

Janzen D. H. 1967. Synchrony of sexual reproduction of trees within the dry season in Central America. Evolution 21:620-637.

Johnston, M. O. and D. J. Schoen. 1994. On the measurement of inbreeding depression. Evolution 48(5):1735-1741.

Kral, R. 1960. A Revision of Asimina and Deeringothamnus (Annonaceae). Brittonia 12(4):233-278.

Kunin, W. E. and A. Shmida. 1997. Plant reproductive traits as a function of local, regional, and global abundance. Conservation Biology 11(1):183192.

Lambert, B. B. and E. S. Menges. 1996. The effects of light, soil disturbance and presence of organic litter on the field germination and survival of the Florida golden aster, Chrysopsis floridana Small. Florida Academy of Sciences 59(2):121-137. 
Menges, E. S., and C.V. Hawkes. Interactive effects of fire and microhabitat on plants of Florida scrub. Ecological Applications. In press.

Menges, E. S., and J. Kimmich. 1996. Microhabitat and time-since-fire: effects on demography of Eryngium cuneifolium (Apiaceae), a Florida scrub endemic plant. American Journal of Botany 83(2):185-191.

Morán-Palma, P. and A. A. Snow. 1997. The effects of interplant distance on mating success in federally threatened, self-incompatible Hymenoxys herbacea $=H$. acaulis var. glabra (Asteraceae). American Journal of Botany 84(2):233-238.

Myers, R. L. 1990. Scrub and High Pine. In Ecosystems of Florida. R.L. Myers and J. J. Ewell (eds), pp. 150-193. University of Central Florida Press. Orlando, FL.

Newstrom, L. E. and G. W. Frankie. 1994. A new classification for plant phenology based on flowering patterns in lowland tropical rain forest trees at La Selva, Costa Rica. Biotropica 26(2):141-159.

Norman. E. M. and D. Clayton. 1986. Reproductive biology of two Florida pawpaws: Asimina obovata and A. pygmaea (Annonaceae). Bulletin of the Torrey Botanical Club 113:16-22.

Norman, E. M., K. Rice and S. Cochran. 1992. Reproductive biology of Asimina parviflora (Annonaceae). Bulletin of the Torrey Botanical Club 119:1-5.

Okada, H. 1990. Reproductive biology of Polyalthia littoralis (Annonaceae). Plant Systematic Evolution 170:237-245.

Ostertag, R. and E. S. Menges. 1994. Patterns of reproductive effort: time since last fire in Florida scrub plants. Journal of Vegetation Science. 5:176-192. 
Primack, R. B. 1980. Variation in the phenology of natural populations of montane shrub in New Zealand. Journal of Ecology 68:849-862.

Primack, R. B. 1987. Relationships among flowers, fruits, and seeds. Annual Review of Ecology and Systematics 18:409-30.

Rabinowitz, D. 1981. Seven forms of rarity. In Biological Aspects of Rare Plant Conservation. H. Synge (ed.), pp. 205-218. New York, Wiley.

Richardson, D. R. 1989. The sand pine scrub community: an annotated bibliography. Florida Scientist 52(2):65-93.

Ruiz, T. Z. and M.T. K. Arroyo. 1978. Plant reproductive ecology of a secondary deciduous tropical forest in Venezuela. Biotropica 10(3): 221-230.

Schemske D. W., B. C. Husband, M. H. Ruckelshaus, C. Goodwillie, I. M. Parker, and J. G. Bishop. 1994. Evaluating approaches to the conservation of rare and endangered plants. Ecology 75(3):584-606.

Sipes, S. D. and V. J. Tepedino. 1995. Reproductive biology of the rare orchid Spiranthes diluvialis breeding system, pollination, and implications for conservation. Conservation Biology 9(4):929-938.

Sokal, R. R. and F. J. Rohlf. 1981. Biometry, Second edition. W. H. Freeman and Co., New York.

Stebbins, G. L. 1980. Rarity of plant species: a synthetic viewpoint. Rhodora 82(9):77-86.

U. S. Fish and Wildlife Service. 1988. Recovery Plan for three Florida pawpaws. U. S. Fish and Wildlife Service, Atlanta, Georgia. 
U. S. Fish and Wildlife Service. 1996. Recovery Plan for nineteen Central Florida scrub and high pine plants. U.S. Fish and Wildlife Service, Atlanta, Georgia.

Waser, N. M. 1983a. The adaptive nature of floral traits: Ideas and evidence In Pollination Biology. L. Real (ed.), pp. 241-285. Academic Press. Orlando, Florida.

Waser, N. M. 1983b. Competition for pollination and floral character differences among sympatric plant species: A review of evidence. In Handbook of Experimental Pollination Biology. C. E. Jones and R. J. Little (eds.), pp. 277-293. Van Nostrand Reinhold, New York.

Weller, S. G. 1994. The relationship of rarity to plant reproductive biology. In Restoration of Endangered Species: Conceptual Issues, Planning, and Implementation. Bowles, M. L. and C. J. Whelan (eds.), Chapter 4:90-117. Second Annual Conference of the Society for Ecological Restoration.

Willson, M. F. and D. W. Schemske. 1980. Pollinator limitation, fruit production, and floral display in pawpaw (Asimina triloba). Bulletin of the Torrey Botanical Club 107 (3):401-408.

Wood, D. A. 1997. Official lists of endangered and potentially endangered fauna and flora in Florida. Florida Game and Freshwater Fish Commission, Tallahassee, Florida.

Wunderlin R. P. 1998. Guide to the Vascular Plants of Florida. University Press of Florida. Gainesville, FL. 806 pp.

Young, C. C., and E. S. Menges. Gap-phase and microhabitat specialization: postfire regeneration of scrubby flatwoods communities in the Lake Wales Ridge. Florida Scientist. In Press. 
Table 1. Flower phases and duration in days (mean $\pm S D$ ) that flowers remain in each phase for Asimina reticulata and A. tetramera at JDSP in 1995.

Flowers were monitored daily in phases 1-5; hourly in phases $5 \& 6$ during anthesis; and daily in phase 7 until fruit ripened. Fruit ripening is also shown in weeks.

\begin{tabular}{cccc}
\multicolumn{2}{c}{ Asimina reticulata } & \multicolumn{2}{c}{ Asimina tetramera } \\
$\mathrm{n}$ Mean SD Range & $\mathrm{n}$ Mean
\end{tabular}

Flower phases (days)

$\begin{array}{lllllllll}1 & 16 & 4.1 & (2.33) & 2-9 & 25 & 11.8 & (4.63) & 5-15 \\ 2 & 20 & 4.6 & (1.82) & 2-8 & 26 & 4.9 & (1.62) & 3-8 \\ 3 & 16 & 2.9 & (0.93) & 1-4 & 25 & 4.0 & (1.72) & 1-8 \\ 4 & 18 & 2.0 & (0.77) & 1-4 & 25 & 1.9 & (0.83) & 1-4 \\ 5 & 23 & 2.3 & (0.96) & 1-5 & 25 & 2.2 & (1.13) & 1-5 \\ 6 & 19 & 1.2 & (0.42) & 1-2 & 21 & 1.1 & (0.36) & 1-2\end{array}$

Fruit phase

7

46

15

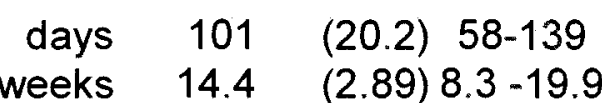

78

(19.0) $\quad 56-95$

11.1

(2.71) $8.0-13.6$ 


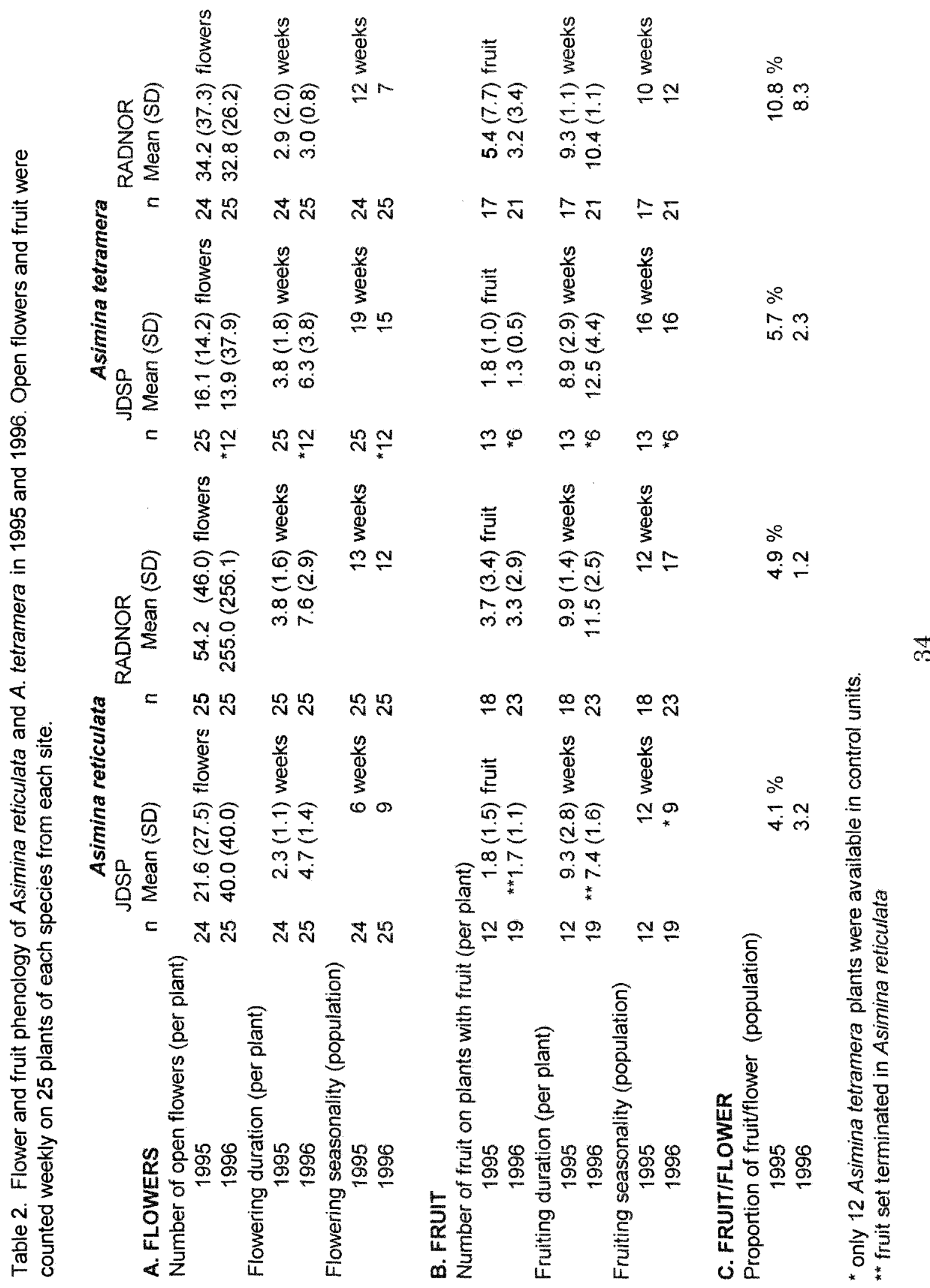


Table 3. ANOVA for flower and fruit on 25 Asimina reticulata and 25 A. tetramera plants in 1995 and 1996 at JDSP and DRP. Data are square root transformed.

Effect

A. FLOWERS

Asimina reticulata

Year

Site

Year $x$ Site

Error

Asimina tetramera

Year

Site

Year $x$ Site

Error df

MS

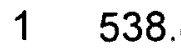

1799.7

1214.6

96

${ }^{*} P$ indicates significance $(<0.05)$

B. FRUIT

Asimina reticulata

Year

Site

Year $x$ Site

Error

$\begin{array}{rrrl}1 & 9.13 & 1.41 & 0.237 \\ 1 & 116.44 & 18.07 & 0.001 \\ 1 & 17.62 & 2.73 & 0.101 \\ 96 & & & \end{array}$ *

Asimina tetramera

Year

Site

Year $\mathrm{x}$ Site

$\begin{array}{rrrl}1 & 0.74 & 1.85 & 0.177 \\ 1 & 5.90 & 14.76 & 0.001 \text { * } \\ 1 & 0.01 & 0.02 & 0.901 \\ 96 & & & \end{array}$

$\begin{array}{rrrl}1 & 0.61 & 1.09 & 0.299 \\ 1 & 11.51 & 20.56 & 0.001 \text { * } \\ 1 & 0.20 & 0.36 & 0.548 \\ 96 & & & \end{array}$

${ }^{*} P$ indicates significance $(<0.05)$ 
Table 4. ANOVA for fruit-set for hand self-, cross-, and open-pollinated flowers in 1995 and 1996 at JDSP and DRP.
A. Asimina reticulata
B. Asimina tetramera

Effect

df $\quad$ MS $F$

df $\quad$ MS $F \quad P$

Year

13.0057 .0

0.001 *

$11.5224 .50 .001^{*}$

Site

$\begin{array}{llll}1 & 0.05 & 0.8 & 0.325\end{array}$

$2 \quad 3.7170 .4 \quad 0.001$ *

$\begin{array}{lllll}1 & 0.85 & 13.7 & 0.001 & \text { * }\end{array}$

Treatment

$\begin{array}{llll}1 & 0.00 & 0.0 & 0.946\end{array}$

21.05 $16.90 .001^{*}$

Year $x$ Site

$\begin{array}{llll}2 & 0.02 & 0.3 & 0.729\end{array}$

10.03

0.50 .474

Year $x$ Treatment

$\begin{array}{llll}2 & 0.03 & 0.6 & 0.534\end{array}$

20.19

3.00 .050 *

Site $x$ Treatment

$\begin{array}{ll}2 & 0.42\end{array}$

20.56

9.10 .001 *

Year $x$ Site $x$ Treatment

288

$0.8 \quad 0.449$

Error

$\begin{array}{ll}2 & 0.04\end{array}$

0.60 .539

234

${ }^{*} P$ indicates significance $(<0.05)$ 
Table 5. Results of controlled self-, cross-, and open-pollinations for Asimina reticulata and $A$. tetramera in 1995 and 1996. ( $n=$ number of plants each treatment). The index of self-incompatibility (ISI) is a proportion of the number of flowers that set fruit by self- and cross-pollinated flowers.

$\mathrm{SI}=$ self-incompatible $(0-0.2), \quad I N C=$ incomplete self-incompatibility $(0.02-1.0)$, and $S C=$ self-compatible $(>1.0)$.

n Selfed Crossed Open Index

Asimina reticulata

1995

$\begin{array}{lllllll}\text { JDSP } & 25 & 0.03 & 0.41 & 0.12 & 0.08 & \mathrm{SI} \\ \text { RADNOR } & 25 & 0.03 & 0.46 & 0.05 & 0.06 & \mathrm{SI}\end{array}$

1996

$\begin{array}{lllllll}\text { JDSP } & 25 & 0.12 & 0.72 & 0.24 & 0.17 & \text { SI } \\ \text { RADNOR } & 25 & 0.16 & 0.64 & 0.16 & 0.25 & \text { INC }\end{array}$

Asimina tetramera

1995

$\begin{array}{ll}\text { JDSP } & \\ \text { RADNOR } & \\ & 1996\end{array}$

JDSP

$12 \quad 0.33$

0.25

0.17

1.33 SC

RADNOR

$25 \quad 0.36$

0.72

0.16

0.50

INC 


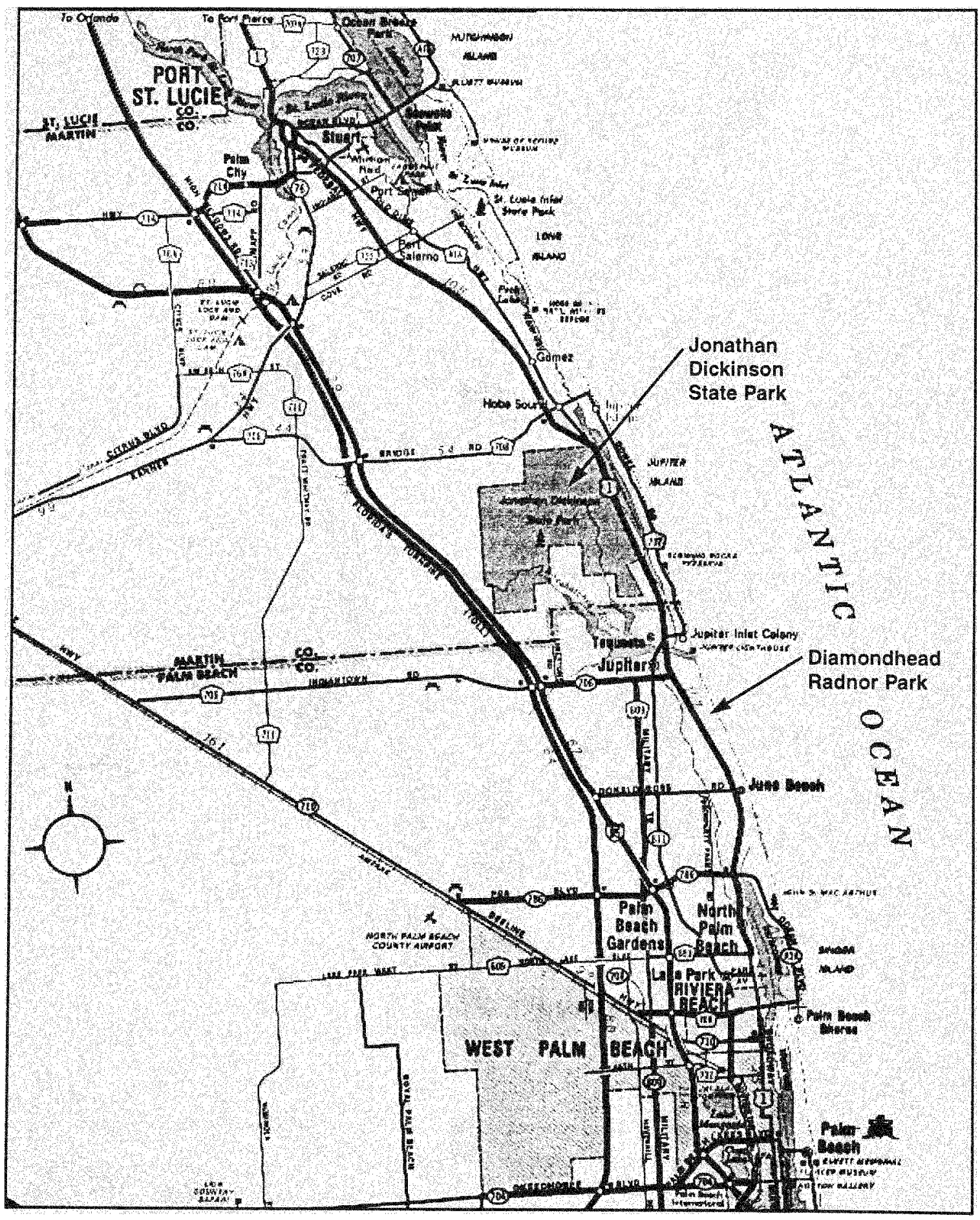

Figure 1. Locations of research sites in Martin and Palm Beach Counties. 


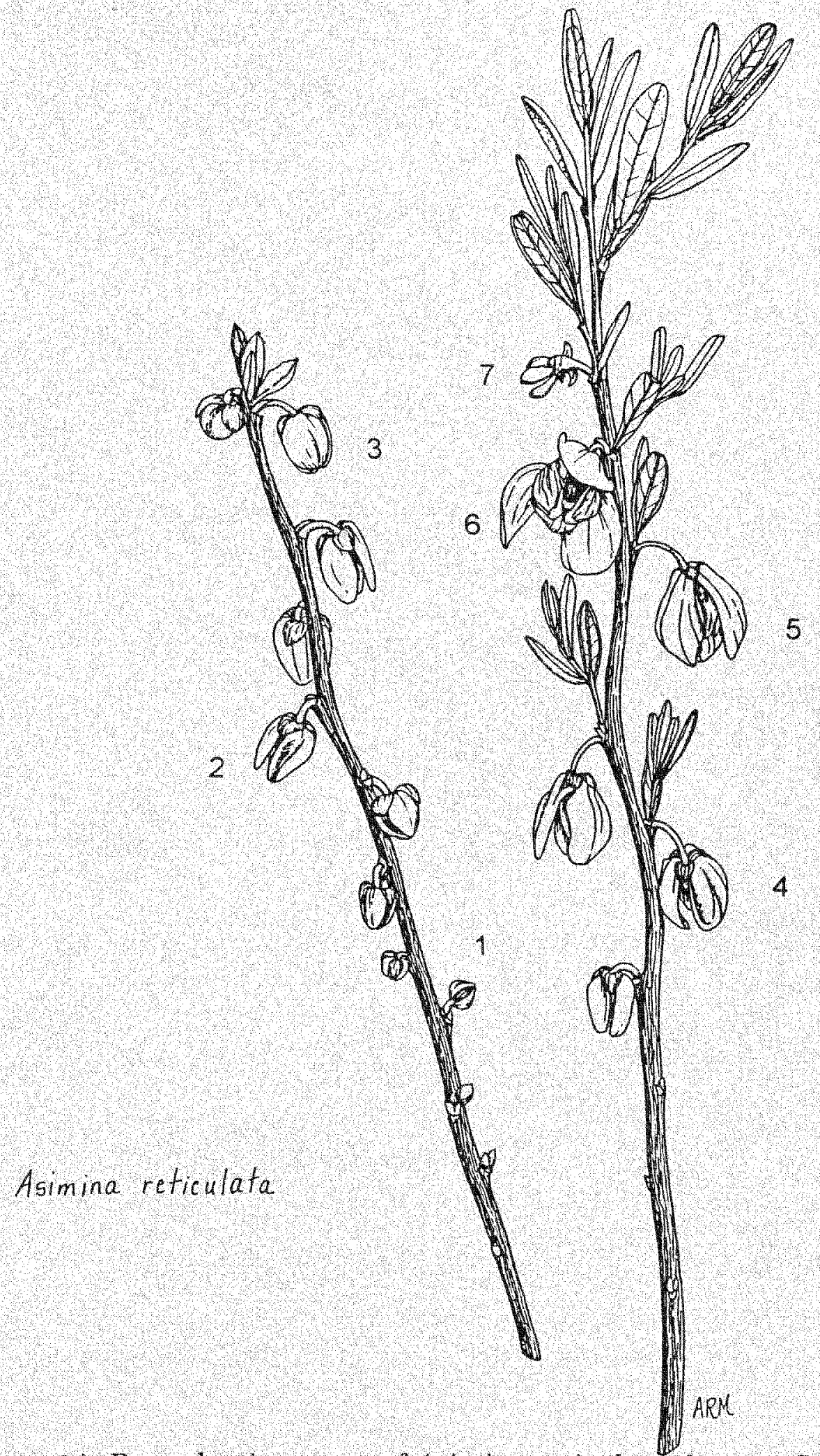

Figure 2A. Reproductive stems of Asimina reticulata showing flowers in phases 1-7. 


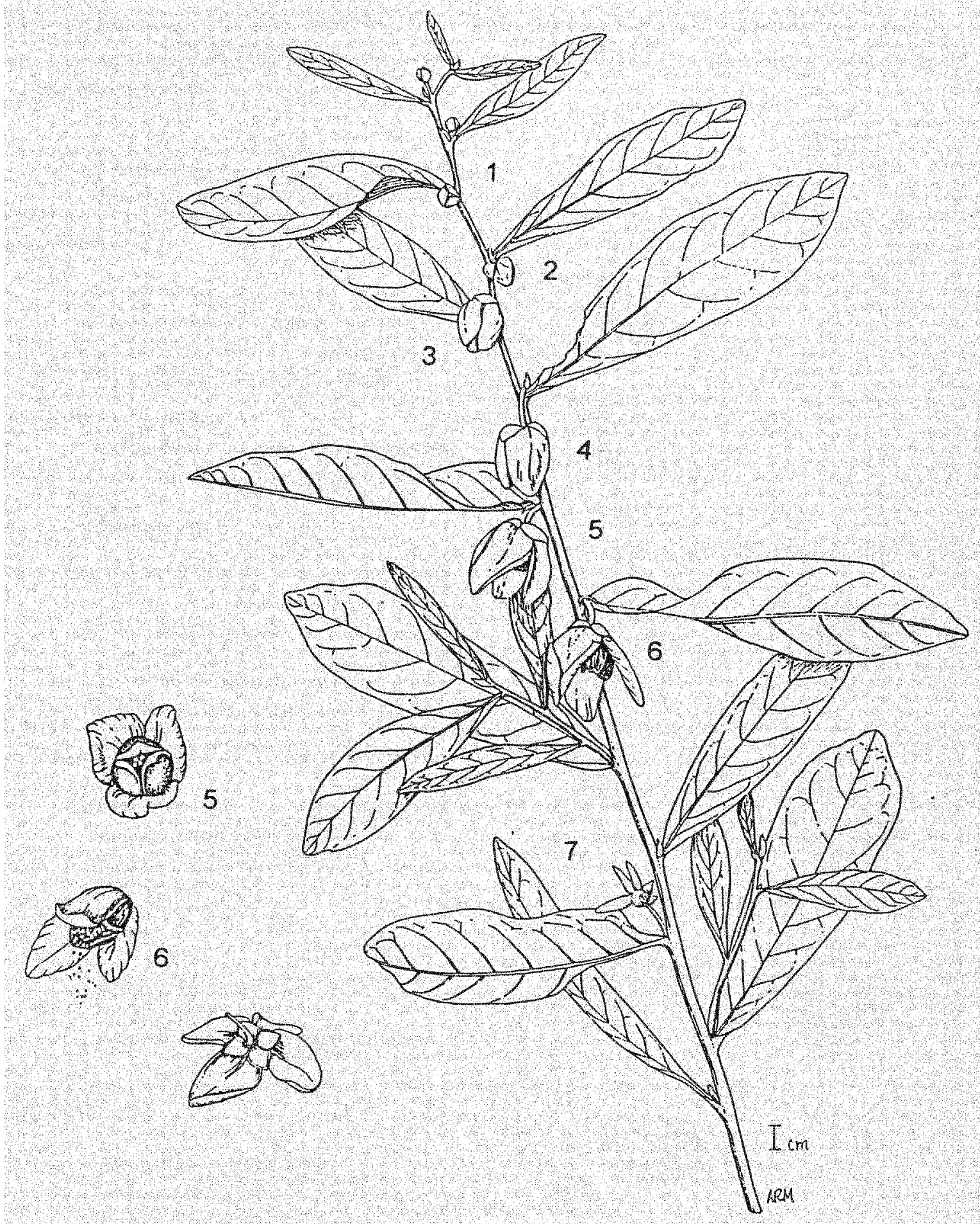

Figure 2B. Reproductive stems of Asimina tetramera showing flowers in phases 1.7. 


\begin{tabular}{|c|c|c|}
\hline Description & Side view & Face view \\
\hline $\begin{array}{l}\text { 1. DORMANT BUD } \\
\text { Calyx brown, closed } \\
\text { Sepals begin to expand, turn green } \\
\text { - Peduncle elongates, buds "nod" }\end{array}$ & & \\
\hline $\begin{array}{l}\text { 2. BUDS OPEN } \\
\text { Sepals elongate, open } \\
\text { - } \quad \text { Outer petals } 2 \times \text { sepal length } \\
\text { - } \quad \text { Inner petal = outer petal length } \\
\text { - }\end{array}$ & & \\
\hline $\begin{array}{l}\text { 3. PETALS ELONGATE* } \\
\text { - } \\
\text { Petals cover stigma, flower closed } \\
\text { - } \\
\text { Outer petals } 3 \times \text { sepal length } \\
\text { - } \\
\text { Inner petal = outer petal length } \\
\text { Corrugated tissue green }\end{array}$ & & \\
\hline $\begin{array}{l}\text { 4. FLOWER MATURATION (Green phase) } \\
\text { - } \quad \text { Outer petals green to cream - open } \\
\text { - } \\
\text { Outer petals longer than inner petals } \\
\text { - }\end{array}$ & & \\
\hline $\begin{array}{l}\text { 5. FLOWER RECEPTIVE (Maroon phase) } \\
\text { - } \\
\text { Outer and inner petals cream, open } \\
\text { - } \\
\text { Corrugated tissue maroon } \\
\text { Stigmas glisten, receptive } \\
\text { Odor emitted }\end{array}$ & & \\
\hline $\begin{array}{l}\text { 6. MALE PHASE } \\
\text { Outer petals wide open } \\
\text { Inner petals wide open } \\
\text { - } \\
\text { - }\end{array}$ & & \\
\hline $\begin{array}{l}\text { 7. FRUIT SET } \\
\text { Petals fall from flower } \\
\text { - } \\
\text { Carpels develop or } \\
\text { Flower abscises and falls }\end{array}$ & & \\
\hline
\end{tabular}

Figure 3A. Asimina reticulata flower phases 1-7. 


\begin{tabular}{|l|l|}
\hline \multicolumn{1}{|c|}{ Description } \\
\hline 1. DEVELOPING BUD \\
$\begin{array}{l}\text { Bud enlarges as shoot elongate } \\
\text { Bud sessile } \\
\text { Sepals green }\end{array}$ \\
\hline -
\end{tabular}

* Some flowers are yellow

Figure 3B. Asimina tetramera flower phases 1-7. 

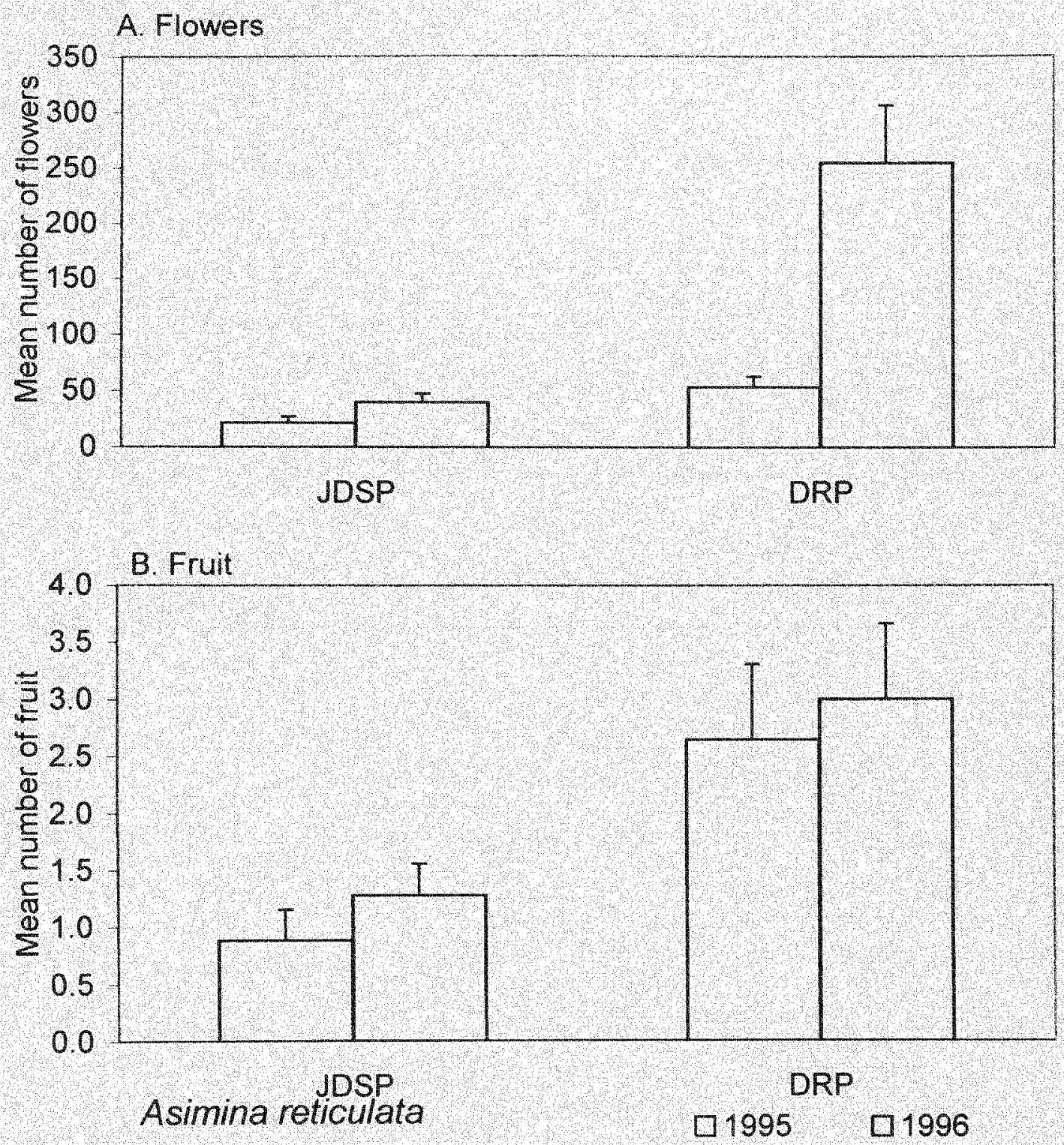

Figure 4. Mean (SE) number of (A) flowers and (B) fruit on 25 Asimina reticulata plants at JDSP and DRP in 1995 and 1996. " $P$ indicates significance $(<0.05)$. Zero values are included. 

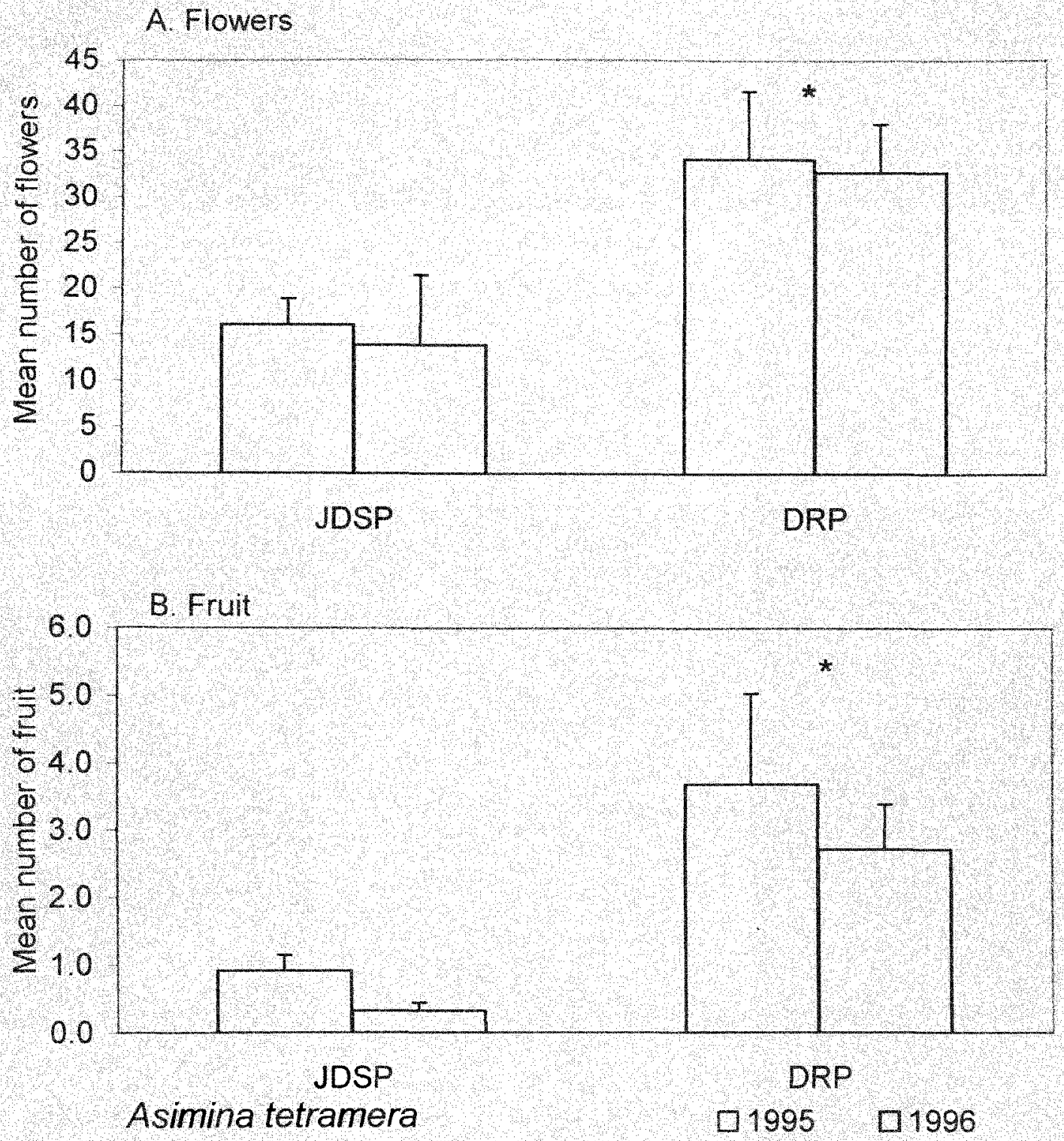

Figure 5. Mean (SE) number of (A) flowers and (B) fruit on 25 Asimina tetramera plants at JDSP and DRP in 1995 and 1996 . ${ }^{*} P$ indicates significance $(<0.05)$. Zero values are included. 

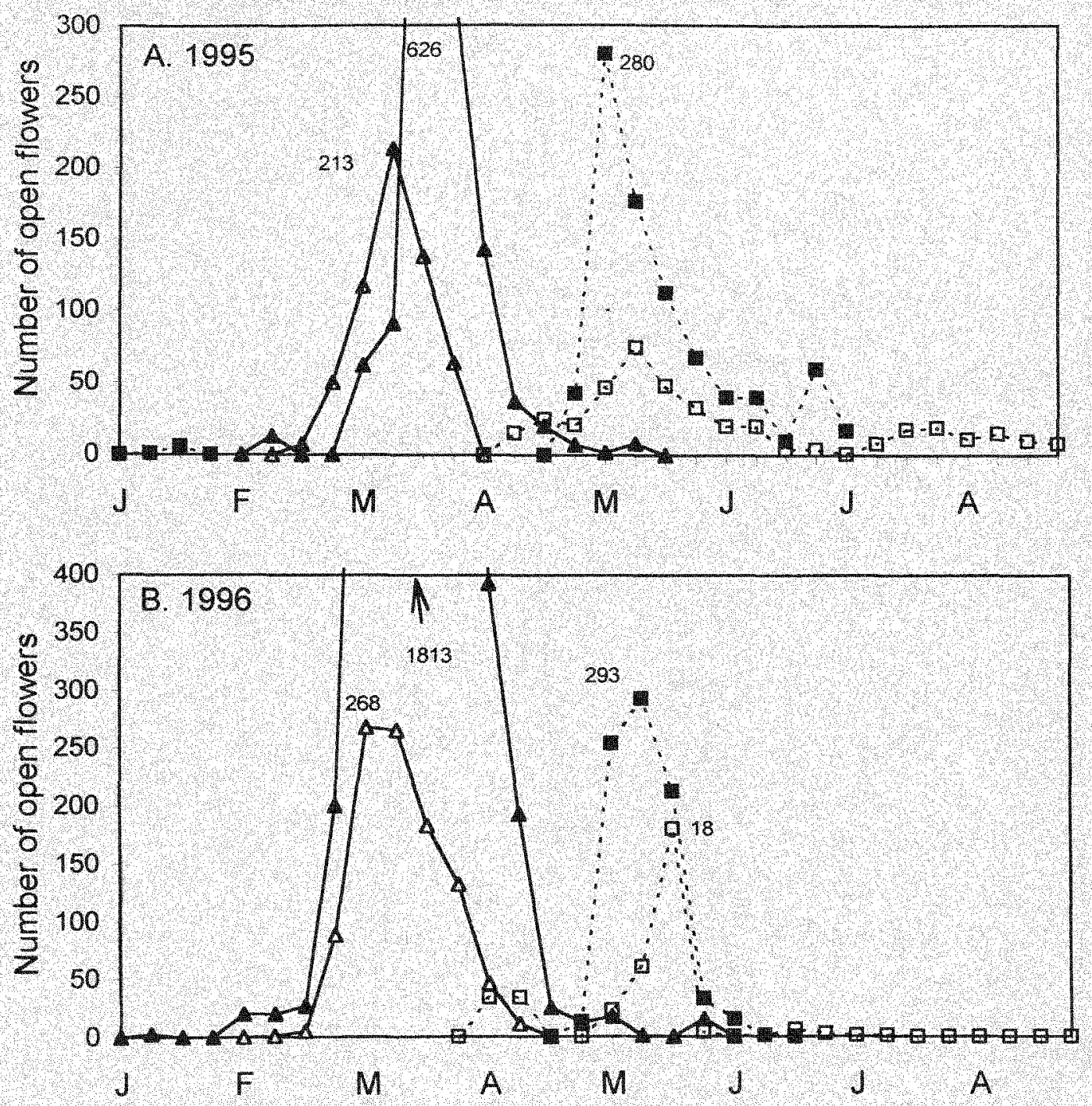

$\rightarrow$ Asimina reticulata JDSP $\longrightarrow$ Asimina reticulata DRP

- . - . Asimina tetramera JDSP $\quad$-...-Asimina tetramera DRP

Figure 6. Flowering phenology for Asimina reticulata and A. tetramera at JDSP and DRP in (A) 1995 and (B) 1996. Open flowers were counted on 25 plants weekly at each site. Note: $y$-axis scales for $A$ and $B$ are different. 

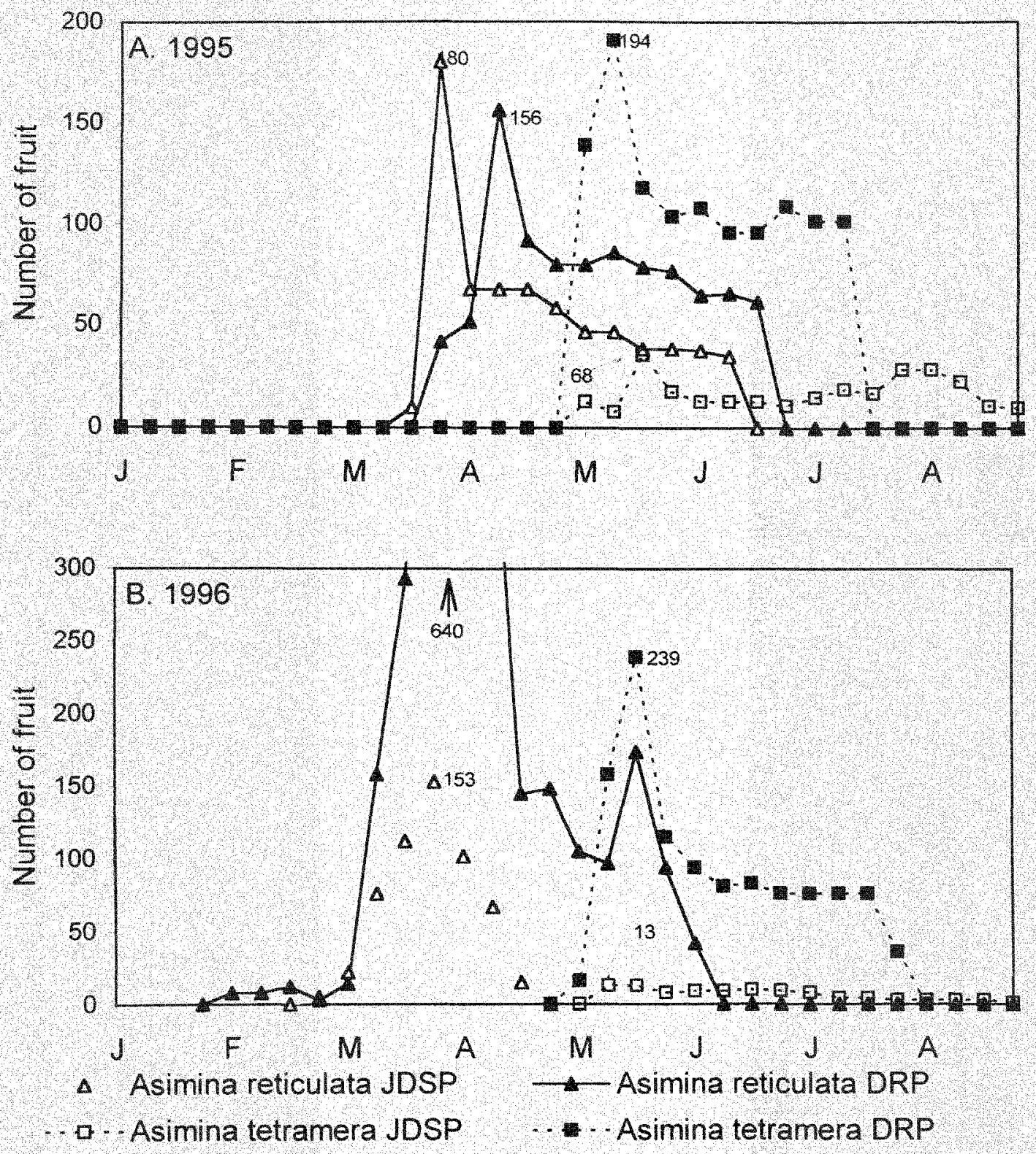

Figure 7. Fruiting phenology for Asimina reticulata and $A$. tetramera at JDSP and DRP in (A) 1995 and (B) 1996. Open flowers were counted on 25 plants weekly at each site. Note: $y$-axis scales for $A$ and $B$ are different. 


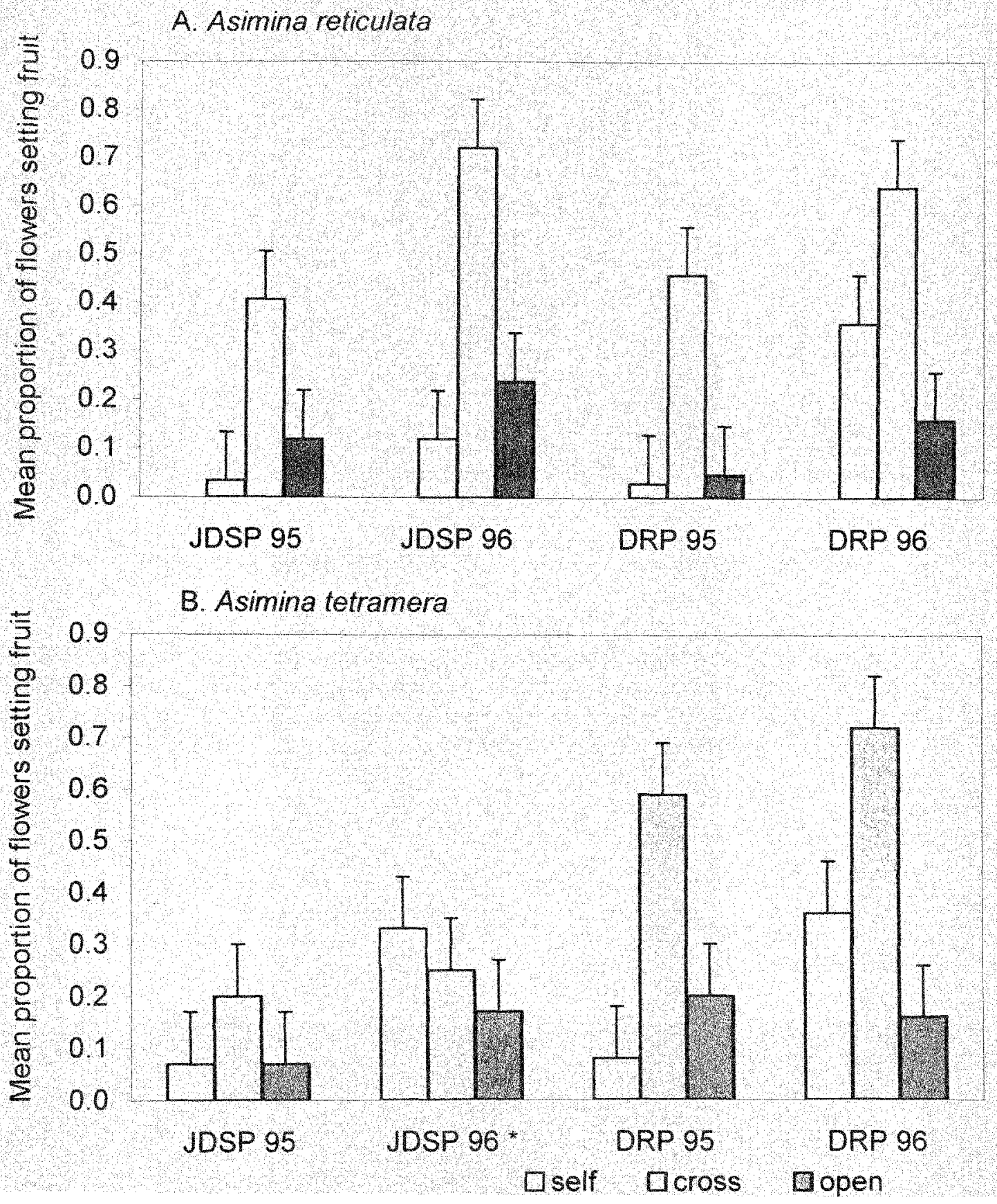

Figure 8 . The effects of three pollination treatments on Asimina reticulata and $A$. tetramera in 1995 and 1996. Flowers were bagged to exclude pollinators in hand self-, and crosspollinations but not in open-pollinations. Hand self-pollination was carried out with self pollen from a flower on the same plant and hand cross with pollen from a plant at least 10 meters away. Error bars indicate 1 SE from the mean. $N=25$ plants at DRP, 20 at JDSP in 1995 and 12 in JDSP in 1996. *A. tetramera at JDSP in 1996 after prescribed burning. 


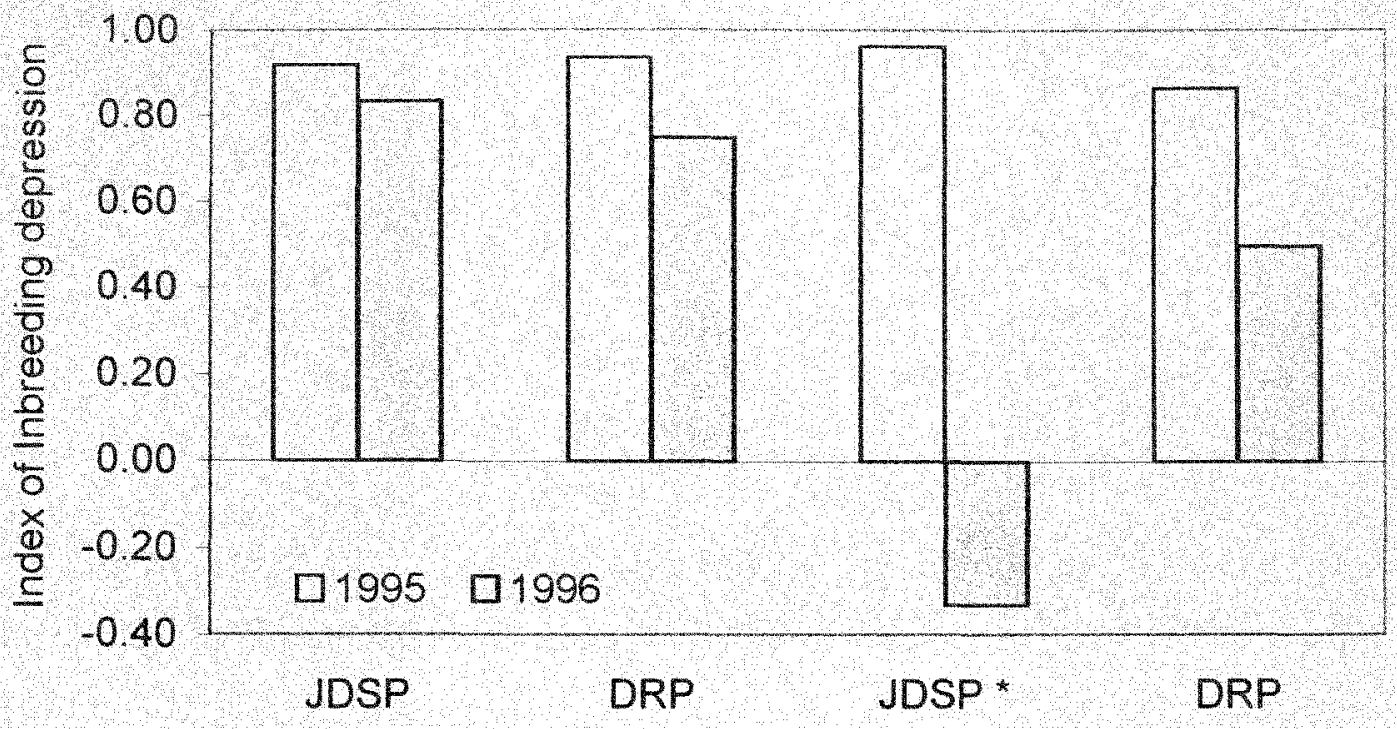

Asimina reticulata Asimina tetramera

Figure 9. Index of inbreeding depression (ID) for Asimina reticulata and $A$. tetramera in 1995 and 1996. The ID was calculated as 1 minus the mean number of flowers setting fruit from hand self-pollinations divided by the mean number of flowers setting fruit from hand cross-pollinations. " $A$. tetramera at JDSP after prescribed burning. 
INSECT FAUNA ASSOCIATED WITH ASIMINA (ANNONACEAE) FLOWERS 


\begin{abstract}
Insects associated with the flowers of the pawpaw, Asimina reticulata
\end{abstract} Chapman and the four-petal pawpaw, A. tetramera Small, were studied in sand pine scrub habitat in southeastern Florida from 1994-1996 in Jonathan Dickinson State Park (Martin County) and at Diamondhead Radnor (Palm Beach County). The most commonly represented orders were Coleoptera (25 spp.), Lepidoptera (3 spp.), and Hymenoptera (3 spp.). All Coleoptera were flower visitors; one species visited flowers of the two Asimina species at both sites: Euphoria sepulchralis (Fabricius) (Scarabeaidae). Two rare species of beetles (Cerambycidae) visited: Ancylocera bicolor (Oliver) and Zagymnus clerinus (Horn). Eggs and larvae of Eurytides marcellus (Cramer) (Lepidoptera: Papilionidae) were observed on both species of Asimina during each year of the study. Omphalocera sp. (Lepidoptera: Pyralidae) larvae were numerous on both species after a 1996 prescribed burn but had not been collected from the mature scrub during the previous two years.

Key Words: Pawpaw, Asimina, sand pine scrub, beetle, endemic, pollinators Florida 


\section{INTRODUCTION}

The Annonaceae is a large, mainly tropical family of trees and shrubs consisting of 128 genera and over 2,000 species (Heywood 1978). Asimina Adanson and Deeringothamnus Small are the two temperate genera in the family. Of the eight species of Asimina, four are endemic to Florida: $A$. obovata (Willd.), A. pygmaea (Bartr.), A. reticulata Chapm., and A. tetramera Small (Kral 1960). Asimina obovata occurs in well drained sandy soils on coastal dunes and hammocks, sand pine or long-leaf pine-scrub oak ridges. The range extends from north central Florida to Lake Okeechobee (Godfrey 1988). Asimina pygmaea occurs in pine flatwoods and ranges from northern Florida south almost to Lake Okeechobee (Godfrey 1988). Asimina reticulata, the common pawpaw, has a wide geographic range within peninsular Florida, inhabiting not only the dry xeric scrub habitat of relict dunes, but also the poorly drained soils of seasonally wet pine savannas and slash or long leaf pine/saw palmetto flatwoods (Godfrey 1988).

Asimina tetramera, the four-petal pawpaw, is restricted to sand pine scrub habitat in Palm Beach and Martin Counties on the Atlantic Coastal Ridge in southeastern Florida (USFWS 1988). An estimated 1,000 plants are known from 16 sites in this sand pine scrub community (Farnsworth 1988). As part of a larger study on the reproductive biology of Asimina reticulata and $A$. tetramera, a wide array of insects were discovered in association with the flowers. This paper enumerates these arthropods. 
Sand pine scrub habitat in Florida is typically characterized by sand pine, Pinus clausa (Chapm. ex Engelm.) Vasey ex Sarg., and a dense understory of evergreen oaks (Quercus geminata Small, Q. chapmanii Sarg., Q. myrtifolia Willd.), rosemary (Ceratiola ericoides Michx.), staggerbush (Lyonia fruticosa (Michx.) Torr.), wax myrtle (Myrica cerifera L.), and saw palmetto (Serenoa repens Small) (Myers 1990). These relatively few shrub species contribute to the uniform appearance of scrub, although the species composition varies from site to site. Scrub occupies sandy, excessively drained, nutrient-deficient soils and may or may not have a pine canopy. The shrub layer may be dense oak thickets or have widely spaced oaks with open sandy areas and in some areas the shrub layer may consist of pure stands of Florida rosemary. Herbaceous species in the ground layer are sparse and lichens may be locally abundant (Cladonia Wigg.).

Scrub habitat is maintained by high-intensity, low frequency (20 to 60 years) crown fires. The disturbances caused by these periodic fires add to the structural and compositional complexity during the first few years after fire by removing the canopy and shrub layer and creating gaps for the colonization of herbs and small perennial shrubs (Schmalzer and Hinkle 1992b, Hawkes and Menges 1996). Changes in oak/saw palmetto dominated scrub returned to pre-fire status in 7-11 years (Schmalzer and Hinkle 1992a). Fire applied too often or excluded for long periods of time may shift the disturbance regime and may affect both the structure and species 
composition (Abrahamson and Abrahamson 1996, Menges and Hawkes in press). Composition alterations associated with the structural changes may cause a reduction or loss of local species or a shift in species composition. Sand pines may be lost if scrub is burned too frequently (Laessle 1965, Richardson and Williamson 1988). Species that regenerate from seed may be lost if insufficient time has elapsed for plants to reach reproductive age (Johnson 1982, Schmalzer and Hinkle 1992b). Sand pine scrub burned after a long fire interval may not regenerate pines, rosemary, or herbaceous species usually characteristic of early post fire years (Richardson 1977, Johnson 1982, Peroni and Abrahamson 1986, Abrahamson and Abrahamson 1996).

Many plant and animal species are restricted to scrub habitat and many of these are listed as rare or endangered (Austin 1976, Austin and Tatje 1979, Christman and Judd 1990, Myers 1990). Endemic plants may have wide ranges throughout scrub or may be locally abundant within a restricted range (Christman and Judd 1990, Myers 1990). An estimated $40 \%-60 \%$ of the plant species are endemic (Austin 1976) and a higher proportion of the plant endemics are found in the Central Ridge scrub than in the Atlantic Coastal Ridge scrub (Christman and Judd 1990). A diverse group of animals are also endemic, including mammals, birds, reptiles, amphibians, and arthropods (Austin et al. 1987, Christman and Judd 1990, McCoy and Mushinsky 1992, Greenberg and Thomas 1995). In a preliminary 
survey, Deyrup (1989) listed 47 arthropods endemic to scrub habitat, exceeding the 33 endemic plant species listed by Austin et al. (1987). However, the number is conservative as the distribution of endemic arthropods is poorly documented (Deyrup 1989).

Annonaceae is the largest family in the order Magnoliales, taxa considered to be representative of ancient extant flowering families (Schatz and Le Thomas 1993). Certain aspects of the ancestral conditions are retained in survivors of groups that were formerly more widespread. Morphological characteristics considered as ancestral include: chromosome numbers, epidermal structure, pollen grains, flower vascularization, and flower structure (Thien 1980). Floral shapes in Annonaceae are diverse and flowers have perianth parts in threes, a variable number of free floral parts, and a large number of spirally arranged stamens (Endress 1994). Important pollinators of two ancient extant families (Winteraceae and Degeneraceae) closely related to Annonaceae, include Diptera, Thysanoptera, primitive Lepidoptera, and Coleoptera (Thien 1980).

Some flowers are pollinated only by beetles and these flowers have distinctive adaptations associated with the beetle groups. Flowers pollinated exclusively by small weevils (Curculionidae) provide shelter through narrow entrances into an inner space where the beetles may remain for a long time. Nadel and Peña (1993) reported that sap beetles (Nitidulidae) enter female phase flowers of Atemoya (Annonaceae) and remain until the end of the male 
phase when stamens are shed. The duration of beetle visits was correlated with the presence of stamens (Nadel and Peña 1993).

Flowers of Annonaceae are generally dichogamous and protogynous (Gottsberger 1990). The bisexual flowers have first a female phase then a male phase; the stigmatic surface is receptive before the anthers release pollen. Intrafloral self-pollination is prevented by the separation of male and female phases, indicating a tendency toward cross-pollination (Gottsberger 1990). However, incomplete dichogamy may allow autogamy or intrafloral selfing. Geitonogamous pollination, or pollination between flowers on the same plant, is likely, especially in plants producing large numbers of flowers. Asimina species are protogynous and cross-pollinated flowers set more fruit than hand self-pollinated flowers or open-pollinated flowers (Norman and Clayton 1986, Norman et al. 1992, Willson and Schemske 1980). Asimina species have flower structures and functions suitable for beetle pollination. Flower characteristics include numerous stamens, sometimes trap-or shelter-enclosed flowers, and sticky pollen (Endress 1994). Copious pollen is released as tetrads and held together by viscin threads from the pollen sacs. Pollen tetrads in loose aggregates increase the likelihood of pollination (Endress 1994). A floral chamber is formed by the three inner petals with grooved, saccate structures that cover the stamens and provide food for insects (Kral 1960). Asimina are primarily pollinated by beetles, attracted by the fruity scent of flowers (Nadel and Peña 1989, 
Murray 1993, Nadel and Peña 1993), although Dipterans are pollinators of taxa with carrion scent (Norman et al. 1992, Willson and Schemske 1980). Kral (1960) observed pollen beetles (Trichotinus piger Fab.), flower beetles, and thrips around flowers, but did not determine the pollinating agents. Norman et al. (1992) determined two pollination syndromes in Asimina. Asimina triloba L. Dunal and $A$. parviflora inhabit wet woods and are fly pollinated; the other three upland Asimina spp. (pinewoods, sandhills and scrub) are cantharophilous (Norman et al. 1992). Beetles were the primary visitors observed on $A$. obovata and A. pygmaea (Norman and Clayton 1986).

Beetles known to pollinate Annonaceous flowers are from several families: Chrysomelidae, Cerambycidae, Curculionidae, Nitidulidae, Scarabaeidae, Staphylinidae, and Tenebrionidae (Endress 1994). Beetles in Chrysomelidae, Staphylinidae, Cantharidae, and Cerambycidae pollinate relatively unspecialized polyphyllic flowers, flowers with a large spectrum of pollinators, such as flies, bees, and butterflies (Endress 1994). Rollinia mucosa (Jacquin) Baillon, a tropical American species, is pollinated by beetles (Staphylinidae and Nitidulidae) (Webber 1992). The beetles enter the partly opened protogynous flowers in the female stage and remain through the pollen liberation male phase, leaving only when the petals fall. The sweet yeasty scent emitted by Rollinia attracts the insects, but flowers do not have a pollen chamber and the food reward is pollen (Webber 1992). Nitidulidae are important pollinators of commercially grown Annona spp. 
(Nadel and Peña 1993, Peña and Bennett 1995). Although flies and bees also visit flowers, they are less likely to be Annonaceae pollinators because they can only enter fully opened flowers in the male phase after pollen has been liberated (Webber 1992).

Two specialist herbivores of Asimina in Florida are Lepidopteran larvae, the zebra swallowtail butterfly, Eurytides marcellus (Papilionidae), and a moth, Omphallocera munroei Martin (Pyralidae) (Tietz 1973). Adult E. marcellus butterflies oviposit on new expanding foliage of Asimina. The young leaf specialist larvae (instars 1-3) depend on the new foliage for their development, but later instars can consume older leaves (Damman and Feeny 1988, Damman 1989). Larvae of all ages eat flowers (unpublished data). Omphallocera munroei larvae feed on mature leaves in groups of 2-50 individuals (Damman 1989). Asimina plants respond to the severe damage caused by high larval densities of $O$. munroei by putting on new growth. The new growth provides oviposition sites for E. marcellus late in the summer when oviposition sites are scarce, thus extending reproduction and generating a multi-voltine life cycle (Damman 1989).

This research is part of a larger study of the reproductive biology of two Florida pawpaws, Asimina reticulata and Asimina tetramera, and a habitat management project. This investigation was conducted to determine: 1) floral insect visitors, 2) potential pollinators, and 3) insect herbivores associated with Asimina flowers in mature sand pine scrub habitat. 


\section{MATERIALS AND METHODS}

\section{Study Sites}

The study sites at Jonathan Dickinson State Park (JDSP) in Martin County and Diamondhead Radnor Park (DRP) in Palm Beach County are mature sand pine scrub habitats with a canopy of sand pines, a shrub understory of oaks and a sparse ground layer. However, DRP has large areas of open sand and clustered sand pines occupying ca. $20 \%$ of the area. In contrast, the JDSP site has small, open, sandy areas, and a continuous sand pine canopy $(86 \%, \pm 11.7, \mathrm{n}=40)$. Tree cores at JDSP show mature pines reaching 78 years and the mean age of 49.5 years $( \pm 13.9, n=40)$. Portions of both sites were disturbed by human activities in the 1940's. Camp Murphy, a U.S. Army base occupied JDSP with partial clearing, and farming occurred in areas cleared of vegetation at DRP. No fire history is recorded for either site, and no fire evidence is apparent. In the spring of 1996 , a prescribed burn was conducted in 2 ha of the JDSP study site (Cox and Roberts unpublished; Chapter III).

\section{Asimina Species}

Asimina reticulata and $A$. tetramera coexist in the 4.05 ha study area at JDSP. At DRP, the two Asimina species tend to be clustered in areas ca. $0.5 \mathrm{~km}$ apart on the 25 ha site, although several individuals of each species are in each cluster. The DRP population of $A$. reticulata occurs in a 3 ha scrub bulldozed in the early 1980's. By contrast, the Asimina tetramera 
plants occur in mature, undisturbed open scrub (4 ha). On each site, twentyfive adult plants of each species were marked in 1994 and the number of open flowers were counted weekly in 1995 and 1996.

Flower differences between $A$. reticulata and $A$. tetramera include size, color, odor, and season of flowering. The flowers of $A$. reticulata have white to cream colored obovate to ovate outer petals ( 3 to $7 \mathrm{~cm}$ long); the deltoid inner petals are one-third to one-half the outer petal length and have a band of maroon corrugated tissue; when mature, the flowers emit a fruity odor (Kral 1960). Asimina tetramera flowers are smaller, and the outer petals (2 to $3.5 \mathrm{~cm}$ long) are ivory with margins rolled toward the outside (Fig. 1). The ovate inner petals are one-third to one-half the size of the outer petals, thicker, and also have rolled margins; the inner petals and corrugated tissue turn dark maroon when mature and emit a fetid odor. Both species are protogynous and the stigmatic surface detaches as the anthers release pollen, preventing self-pollination or autogamy. Flowering times for the two species overlap and more flowers are produced by $A$. reticulata than by $A$. tetramera.

\section{Insect Methods}

This study was conducted from 1994 - 1996 during the flowering seasons (Feb. to Aug.). Observations were made weekly at various times from early morning to after dark to determine peak insect activity.

Collections were made before $10 \mathrm{am}$, after $5 \mathrm{pm}$, and after dark from $9 \mathrm{pm}$ to $11 \mathrm{pm}$. Night surveys were made once during the flowering period at each 
site in 1995.

Observations of flower visitors from a distance of three meters yielded little data. An alternative method, opening and inspecting flowers was more productive as many visitors remained in the flowers. Visitors $1.0 \mathrm{~cm}$ or larger in the flowers were easily observed, but smaller visitors could be detected only by opening the inner petals. The flower phase was recorded for flowers with visitors. This method was non-destructive to flowers in the female or pistillate phase, but if the flowers were in the staminate phase and anthers released pollen, the petals and insects fell from the flowers.

Insect behavior and location on the flowers were recorded prior to capture. Twenty-five plants were inspected weekly during the flowering season for both species in 1994 -1996, although flower counts were made in 1995 and 1996. Insects were collected in or on the Asimina flowers. Individuals were examined under a dissecting microscope. Pollen on insects was easily observed because of the large size $(100 \mu \mathrm{m})$ and aggregation by viscin threads. Flowers were also inspected for insect damage and pollen deposition on the stigmatic surfaces. Damage to flowers and the phase of flower development were recorded. Representative insects were collected and small specimens were stored in $70 \%$ alcohol; larger insects were pinned and dried.

Capture techniques included hand-removal or placing plastic bags or kill-jars over the flowers and visitors. This was particularly effective for 
small insects. Insects were identified to order using Borror et al. (1989). Insects were sent to the Florida Department of Agriculture and Consumer Services, Department of Plant Industry, Gainesville for species identification, and will be deposited there after the study.

\section{Statistical Analyses}

Comparisons in the frequencies of insects that were potential pollinators were made between sites for A. reticulata and A. tetramera. Numbers of species in orders and in Coleopteran families were analyzed separately using contingency table analysis to determine differences.

Lepidopteran larvae were not included in the statistical analysis as they are specialist herbivores.

\section{RESULTS}

Thirty-five insect species in 19 families (Table 1) were visitors to Asimina flowers. A total of 316 insects were recorded during the three year period; 220 individuals were associated with Asimina reticulata and 96 individuals with $A$. tetramera (Table 2A). Lepidoptera were represented by three families and 72 individuals. Twenty-five species (78\%) were beetles (Coleoptera) in 11 families and the most likely pollinators of both Asimina species.

\section{Beetles}

The most well represented Coleopteran families were Scarabaeidae, 
with seven species and 66 individuals, Cerambycidae with four species and 48 individuals, and Chrysomelidae with four species and five individuals (Table 2B). Only one beetle was present in both Asimina species at both sites; Euphoria sepulchralis (Fabricius) (Table 1). Their bodies were larger $(14 \times 8 \mathrm{~mm})$ than the flower chamber enclosed by the inner petals. Euphoria sepulchralis were observed in pistillate and staminate phase flowers, but more often in the staminate phase flowers (75\%) eating pollen and corrugated tissue on the inner petals. Pollen was located on their elytra, legs, and mouth parts, where it was very likely to contact receptive stigmas when beetles fed on the corrugated tissue of subsequent flowers in the female phase. These scarabs were the most numerous flower visitors $(n=39)$ in $A$. reticulata at DRP.

Two scrub endemic scarabs were casual visitors and not pollinators. Phyllophaga elizoria Saylor $(\mathrm{n}=9)$, a scrub endemic, was seen only at JDSP on flowers and leaves late in the evening (Table 1). These beetles aggregated on $A$. reticulata at dusk and were gone by morning; they remained outside the perianth and left distinctive brown scratch marks and chewed petals. Phyllophaga latifrons (LeConte) $(\mathrm{n}=2)$ a metallic green beetle was observed on $A$. reticulata at DRP during the day.

For both Asimina species, more beetle species were noted at JDSP (n = 17) than at DRP $(\mathrm{n}=12)$ (Table 1$)$. Typocerus zebra was the most abundant Cerambycidae at JDSP in $A$. reticulata $(\mathrm{n}=31)$, although one individual was 
collected in A. tetramera at JDSP, and one at DRP. Fewer species were observed in $A$. tetramera than in A. reticulata; no species had more than seven individuals at JDSP. Only one species had 13 individuals at DRP, Hymenorus tenellus, a darkling beetle (Tenebrionidae). Plectromerus dentipes, the smallest $(6 \times 1 \mathrm{~mm})$ cerambycid in the study was not seen until flowers were opened by hand. Pollen was observed on the body and mouth parts, but did not adhere to the smooth elytra and legs of $P$. dentipes. These beetles were in both $A$. reticulata $(\mathrm{n}=3)$ and $A$. tetramera $(\mathrm{n}=3)$ at JDSP. Zagymnus clerinus, a rare beetle that breeds in cabbage palms (Sabal palmetto (Walt) Lodd. ex Schultes) was collected only in A. tetramera at $\operatorname{JDSP}(n=4)$.

Although four Chrysomelidae species were in Asimina flowers, only one individual for each of three species was recorded. Neolochmaea dilatipennis Laboissiere, a West Indian species, was exclusive to A. tetramera at $\operatorname{JDSP}(n=1)$ and DRP $(n=1)$. These adult chrysomelids feed on flowers and foliage and may be potential pests rather than pollinators.

Several beetles were observed at both sites and others were only at one site. Polemius sp. (Cantharidae) an important pollinator of $A$. reticulata at $\operatorname{DRP}(\mathrm{n}=16)$ and $\operatorname{JDSP}(\mathrm{n}=9)$ also visited A. tetramera at $\operatorname{JDSP}(\mathrm{n}=1)$. Pollen tetrads were held in the short hirsute hairs on the body, legs and the antennae of this $8 \times 3 \mathrm{~mm}$ beetle. Polemius species are widely distributed but uncommon and usually found in moist areas (White 1983). They prey on 
aphids and other small insects. Hymenorus tenellus (Tenebrionidae) Casey are pollen feeders and were at DRP on both species, but more often in Asimina tetramera $(\mathrm{n}=13)$ than $A$. reticulata $(\mathrm{n}=3)$.

Although two beetle species were observed on both plant species, several insects preferred one or the other Asimina species (Table 1). Harmonia axyridis Pallas (Coccinellidae), an introduced lady-bird beetle from Asia, moved from flower to flower on A. reticulata, and was observed more often at JDSP $(n=37)$ than DRP $(n=1)$. This lady-bird beetle was abundant in 1995, but not observed in 1996. Inspection of the interior of flowers showed numerous aphids, prey for adult lady-bird beetles (Borror et al. 1992).

Other beetle species were exclusive to a site and an Asimina. At JDSP, seven species were only on $A$. reticulata and five exclusively on $A$. tetramera. In $A$. reticulata, a single individual was collected from two Chrysomelidae, one Curculionidae, one Lagriidae, and a Melyridae. At DRP, two species Notolomus basalis LeConte (Coccinellidae) and Anomala innuba (Fabricus) (Scarabaeidae) were present in A. reticulata; and four species Selenophorus palliatus (Fabricus) (Carabidae), Anomea laticlavia angustata Schaffer (Chrysomelidae), Phyllophaga latiferons (Scarabaeidae) and Epitragodes tomentosus Tenebrionidae were in A. tetramera.

\section{Other Insects}

Insect species collected in orders Blattodea, Diptera, Hemiptera, and 
Hymenoptera were not as abundant as species in Coleoptera. Cariblatta lutea (Saussure and Zehntner) (Blattellidae), the only Blattodea, was collected from both sites in Asimina tetramera $(\mathrm{n}=6)$ but not in A. reticulata. Most roaches were already in the flowers, however, one was observed approaching an $A$. tetramera plant from two meters away, climbed the trunk and entered several flowers. Roaches were in male phase flowers and pollen was on the head and mouth parts. Except for beetles, Plecia sp. (Bibionidae: Diptera) were the most numerous species in $A$. reticulata flowers at DRP (n= 7). Pollen was observed on the body and mouth parts of these March flies, better known as "love bugs". One Hemiptera, a Lygaeid nymph was observed in a flower. Hymenoptera was represented by one family (Halictidae), and three species (Table 1). Some of these fairly common bees are easily recognized by their metallic color and while only six were collected in flowers, many more were observed, but not counted, on leaves of both Asimina species.

\section{Herbivores}

Larvae in three families of Lepidoptera were found in Asimina flowers and on new leaf growth (Table 1). Eurytides marcellus, zebra swallowtail, eggs and larvae were observed on both Asimina species throughout the spring and summer each year of the study. Higher numbers of larvae were encountered at JDSP ( $\mathrm{n}=23$ on $A$. reticulata and $\mathrm{n}=31$ on A. tetramera) than at DRP ( $\mathrm{n}=11$ on $A$. reticulata and $\mathrm{n}=7$ on $A$. tetramera). Larval 
herbivore damage was restricted to flowers, new leaf growth, and portions of old leaves. Pyralid moth larvae, Omphallocera sp. were collected at both sites on $A$. reticulata and $A$. tetramera in rolled leaves. After a prescribed burn in May 1996 at JDSP, damage by Omphallocera larvae was noted on $50 \%$ of the $A$. reticulata individuals and on $2 \%$ of the $A$. tetramera plants in the burned area during July, August, and September 1996.

\section{Insects and Flowers}

Numbers of insects observed or collected in flowers varied during the three year study (Figs. 2-4, A, C); numbers of flowers showed more consistency (Figs. 3B, D, 4B, D). Only insects associated with flowers are included in the bar charts (lepidopteran larvae are not included). The number of insects in flowers varied weekly during the three years; from 35 insects on $A$. reticulata in March 1995 to none on many sampling days. More flowers were produced in 1995 and 1996 at DRP than at JDSP for $A$. reticulata $(\mathrm{P}<0.001)$ compared to $A$. tetramera $(\mathrm{P}<0.1)($ Figs. $3 \mathrm{~B}, \mathrm{D}, 4 \mathrm{~B}, \mathrm{D})$. The number of open flowers were not recorded in 1994. No insects were observed on windy (>10 $\mathrm{mph}$ ) or rainy days at either site. Not all plants inspected had visitors even on sunny days. Visitors including ants, leaffooted bugs, flies, and spiders were observed on leaves, stems, and fruit, but are not included in this paper.

Multi-way contingency table analysis for each species separately showed no significant differences when comparing number of species or 
number of individuals in orders between sites. Comparisons among

Coleopteran families for the two species showed no significant differences in number of species in Coleopteran families between the two sites. Significant differences were found between sites for numbers of individuals in Coleoptera families for $A$. reticulata $\left(\chi^{2}=99.7, \mathrm{df}=9, \mathrm{p}<0.001\right)$ and $A$. tetramera $\left(\chi^{2}=28.7, \mathrm{df}=10, \mathrm{p}<0.001\right)$.

\section{DISCUSSION}

Coleopterans are the most likely insect pollinators of both $A$. reticulata and $A$. tetramera, although insects in other orders are flower visitors and some of those may be pollinators (Table 1). Beetles are known pollinators of A. pygmaea and A. obovata (Norman and Clayton 1986). Although flies are more common visitors of $A$. triloba (Willson and Schemske 1980) and $A$. parviflora (Norman et al. 1992) and the morphology and odor of A. tetramera is similar to those species and fits the fly pollination syndrome, no flies were recorded in the flowers of this species in this study. Some beetle species visit both Asimina species, but insects appear to be attracted to either $A$.

reticulata or A. tetramera. Most likely, an assortment of insects, primarily beetles, pollinates each Asimina, and the composition of the assortment varies from site to site and from year to year depending on flower frequency and local environmental conditions.

At JDSP, $83.8 \%$ of the total insects were in three families; 
Cerambycidae, Coccinellidae, and Scarabeaidae and for six families I saw fewer than seven individuals each (Table 2B). Cerambycids are the most important beetles in plant pollination (White 1983). Typocerus, a common genus on flowers, feeds on pollen, stamens, and nectar (Borror et al. 1989); it was the most abundant beetle in $A$. reticulata $(\mathrm{n}=31)$ at JDSP. Norman and Clayton (1986) reported T. zebra as a pollinator for A. obovata. Floral similarities shared by $A$. reticulata and $A$. obovata include: a band of maroon colored corrugated tissue in the inner petals, a sweet aroma, and ovate, white outer petals.

Beetles were three times more likely to be in male phase flowers than in female phase flowers. When disturbed, the beetles either fell from the flowers to the ground, or flew to the top of a flower on a nearby plant. Beetles were not observed moving from a flower on one plant to another on the same plant. I observed a Typocerus zebra individual landing on an unpollinated female phase $A$. reticulata flower, entering and exiting the flower. Pollen was deposited on the stigma and a fruit was produced.

Eighty-two percent of the individual flower visitors at DRP were in two families, Scarabaeidae and Cantharidae (Table 1). Euphoria sepulchralis, common pollen feeding scarabs, were the most abundant beetles in both Asimina flowers at DRP, and the most important generalist pollinators. Large populations of Euphoria sepulchralis may be present at DRP because of the open scrub site and the adjacent bulldozed and mowed areas that have 
cactus, thistle, and other plants with abundant pollen. Polemius sp.

(Cantharidae) were observed in numerous $A$. reticulata flowers at DRP feeding on pollen and aphids. Polemius sp. may be irregular pollinators as they prey on aphids and other small insects. Another beetle that preys on aphids, Harmonia axyridis (a lady-bird beetle), was also present in 1995 in A. reticulata flowers. Asimina pollen was readily observed on the elytra, attached by the viscin threads that hold the pollen tetrads together. The abundance of these two beneficial beetles in 1995 was stimulated by an outbreak of aphids in the mature closed canopy of pines.

\section{Asimina reticulata Beetle Pollinators}

Two beetles, Euphoria sepulchralis and Typocerus zebra, are the most likely pollinators of $A$. reticulata in the mature sand pine habitat at JDSP and DRP (Table 1). Norman and Clayton (1986) determined E. sepulchralis to be the most common pollinator of $A$. pygmaea, and noted E. sepulchralis scarcity in A. obovata. Based on Norman and Clayton's observations, I expected $E$. sepulchralis to visit $A$. tetramera more often because of floral similarities of A. pygmaea and A. tetramera; they both have the maroon corrugated inner petals and yeasty odor. Highest E. sepulchralis numbers were observed in A. reticulata, fewer in A. tetramera at DRP, and even fewer in $A$. reticulata and $A$. tetramera $(\mathrm{n}=3)$ at JDSP. Year to year variability exhibited by $E$. sepulchralis numbers depends on flowering frequencies at different sites because these generalist beetles feed on plants producing 
copious amounts of pollen; visiting cactus (Opuntia spp.), thistles (Cirsium horridulum) and other large flowered species.

\section{Asimina tetramera Beetle Pollinators}

Less than a third (29\%) as many individual beetles were observed in Asimina tetramera $(\mathrm{n}=50)$ compared with $A$. reticulata $(\mathrm{n}=167)($ Table $2 \mathrm{~B})$. The differences in both numbers of species and of individuals in families were significantly higher $(p<0.001)$ at JDSP. At JDSP, Typocerus zebra was the most frequent visitor to both Asimina reticulata and A. tetramera flowers in all three years. Trichotinus rufobrunneus Casey (Scarabaeidae) and Epitragodes tomentosus (LeConte) (Tenebrionidae) were also found by Norman and Clayton (1986) in A. pygmaea. Plectromerus dentipes (Cerambycidae) and Trichotinus rufobrunneus, were collected in flowers of both $A$. reticulata and $A$. tetramera. Both of these beetles were noted by Norman and Clayton (1986) on A. obovata, one of the pawpaws that has fruity scented flowers similar to A. reticulata.

Although several insects appeared to be exclusive to one or the other Asimina, many times only one insect was observed in the flowers. These single occurrences do not provide sufficient information to tell whether these insects are important pollinators, whether many insects are causal visitors, or are potential pests to Asimina species.

\section{Other Insect Visitors}

Insect species that I collected in orders Blattodea, Diptera, Hemiptera, 
and Hymenoptera are possible pollinators on Asimina but were not as abundant as beetles (Table 2A). Flies are known pollinators of $A$. triloba (Willson and Schemske 1980) and A. parviflora (Norman et al. 1992), described as having a musty or yeasty odor. Plecia sp. was the most abundant dipteran I observed in flowers of $A$. reticulata, with the sweet odor and none were captured in A. tetramera with the yeast odor. I also captured several Halictid bees in flowers and they may be casual pollinators.

Although I observed other bees and flies on the foliage, none entered flowers. I initially considered roaches captured in the flowers to be incidental visitors. However, recently roaches have been found capable of pollination (Nagamitsu and Inoue 1997). Their role as pollinators of Asimina warrants further study.

\section{Asimina Flowering}

Asimina flowering phenology varies and the abundance of flowers differs from site to site (Figs. 3B, D, 4B, D). In 1996 flowering for both Asimina species overlapped for a week and insects perhaps move pollen between the two species. Fewer flowers are present at the beginning and the end of the flowering season so that cross-pollination between $A$. reticulata and A. tetramera is possible, though few flowers are available on either species. Asimina tetramera plants flower later in the season, and summer rains begin in June.

Flower-to-flower pollination on the same plant (geitonogamy) is more 
likely to occur during peak flowering as many flowers are in the male and female phase on the same plant. Asimina reticulata produces more flowers per plant than A. tetramera. In 1995 and 1996, JDSP plants produced significantly fewer flowers (Figs. 3B, 4B) than at DRP (Figs. 3D, 4D) for $A$.

reticulata $\left(\mathrm{F}_{1.96}=11.44, \mathrm{p}<0.001\right)$ and $A$. tetramera $\left(\mathrm{F}_{1,96}=18.07, \mathrm{p}<0.001\right)$. During peak flowering, thousands of flowers are available for pollination as the local populations may have 300 plants in flower at one time. Asimina tetramera plants produce fewer flowers during peak season and not all plants produce flowers. The largest $A$. tetramera population is 224 plants, and flowering is not synchronous.

\section{Endemic and Rare Species}

Several species of beetles in the study (Table 1) are rare or endemic in scrub habitat. Two rare Cerambycidae observed at JDSP were collected in $A$. tetramera flowers in 1996. One Ancylocera bicolor and four Zagymnus clerinus were in male phase flowers and had pollen all over their bodies. June beetles in the genus Phyllophaga (Scarabaeidae) are scrub endemics, unknown in other Florida plant communities (Deyrup 1989). Phyllophaga elizoria and P. latifrons, were seen at different sites. At JDSP, P. elizoria was observed at dusk on $A$. reticulata plants and flowers. During February and March in 1994, as many as six P. elizoria could be seen roosting on a single plant at night. The beetles ate the flowers. Only one endemic species, P. latifrons, was observed at DRP during the daytime on A. reticulata. 


\section{Herbivores}

Zebra swallowtail butterflies were observed at both sites each year (1994-1996) from mid-February on A. reticulata. Eurytides marcellus laid eggs on new growth of Asimina and early instar larvae ate young leaves, growing meristems and flowers. Female zebra swallowtail butterflies switched plants for oviposition in late April when A. reticulata leaves matured and $A$. tetramera start leafing-out. Asimina tetramera continued growth and flowering in a few plants through August, especially at JDSP, providing oviposition sites for E. marcellus females. At JDSP, after the May 1996 prescribed burn, A. tetramera plants flowered until February 1997, extending the growing and flowering season and providing new foliage for the larvae (Fig. 4 B).

Omphalocera sp. (Pyralidae) larvae were collected in both habitats in 1994 and 1995; but only a few leaves were damaged as larval densities were low. In May 1996, following a prescribed burn at JDSP (unpublished data), Omphalocera sp. densities increased and larvae were observed on $50 \%$ of the A. reticulata plants in July and August, and on several $A$. tetramera plants in September. Damage was severe on $A$. reticulata, $50 \%$ of the plants, as larvae fed in groups and avoided predators by constructing shelters with mature leaves. Asimina reticulata that were defoliated in August did not produce new growth until the spring of 1996 ; but damaged $A$. tetramera produced new stems and leaves into September after damage caused by Omphalocera sp. 
larvae. Eurytides marcellus eggs were still observed in mid-September. This is the first recorded observation of the interaction between the two lepidopteran species and the two Asimina species in southeastern Florida. Damman (1989) noted this interaction between $E$. marcellus and $O$. munroei on $A$. speciosa Nash, $A$. obovata and hybrids of the two species in the Ocala National Forest in Central Florida.

The low numbers of insects observed in Asimina in this study (Table 2) could be attributed to seasonal environmental patterns or seasonal life cycles of the species. No insects were observed on windy or rainy days at either site. The absence of pollinators on cold or windy days were also noted by Norman and Clayton (1986). Willson and Schemske (1980) found low fruit production for two years $(4 \%, 17 \%)$ in $A$. triloba and their field observations yielded no evidence of insect visitation.

The higher number of insect species at JDSP compared to DRP may be attributable to the large area of the intact scrub habitat. Low numbers of individual animals of each species may be associated with the mature status of the scrub and the closed canopy. Conversely the relatively few species at DRP $(n=75)$ could be related to the fragmented small site and the high numbers of individuals associated with other plant species with abundant pollen. An increase in the numbers of species at JDSP after the prescribed burn in 1996 could be accounted for by the increase in flowering from canopy removal, decreased competition, and other factors. Observations made over a 
longer time period will reveal the patterns of abundance and diversity of insects associated with these two Asimina species. 


\section{LITERATURE CITED}

Austin, D. F, 1976. Florida Scrub. The Florida Naturalist. 49(4):2.

Austin, D. F. and B. E. Tatje. 1979. Endangered Four-petal Pawpaw. In Rare and Endangered Biota of Florida, Volume 5 Plants. D. B. Ward (ed), pp. 5-6. University Presses of Florida.

Austin, D. F., F. Posin and J. Burch. 1987. Scrub species patterns on the Atlantic Coastal Ridge, FL. Journal of Coastal Research 3(4):491-498.

Abrahamson, W. G., and J. R. Abrahamson. 1996. Effects of a low-winter fire on long unburned Florida sand pine scrub. Natural Areas Journal 16(3):171-183.

Borror, D. J., C. A. Tripplehorn, and N. F. Johnson. 1989. An Introduction to the Study of Insects. Harcourt Brace and Company. Orlando, Florida.

Christman, S. P., and Walter Judd. 1990. Notes on plants endemic to Florida scrub. Florida Scientist 53(1):52-73.

Damman, H. 1989. Facilitative interactions between two lepidopteran herbivores of Asimina. Oecologia 78:214-219.

Damman, H. and P. Feeny. 1988. Mechanisms and consequences of selective oviposition by the zebra swallowtail butterfly. Animal Behavior 36 : 563-573.

Deyrup, M. 1989. Arthropods endemic to Florida scrub. Florida Scientist $52(4): 254-270$.

Endress, P. K. 1994. Diversity and evolutionary biology of tropical flowers. Cambridge University Press. 511 pp. 
Farnsworth, S. 1988. Four-petal Pawpaw Survey. Florida Natural Areas Inventory. The Nature Conservancy and The Florida Department of Natural Resources.

Godfrey, R. K. 1988. Trees, shrubs, and woody vines of northern Florida and adjacent Alabama. University of Georgia Press, Athens, Georgia. 734 $\mathrm{pp}$.

Gottsberger, G. 1989. Beetle pollination and flower rhythm of Annona spp. (Annonaceae) in Brazil. Plant Systematics and Evolution 167:165-187.

Gottsberger, G. 1990. Flowers and beetles in the south American tropics. Botanica Acta 103(4):360-365.

Greenberg, C. H. and M. C. Thomas. 1995. Effects of forest management practices on terrestrial coleopteran assemblages in sand pine scrub. Florida Entomologist 78(2):271-285.

Hawkes, C. V. and E. S. Menges. 1996. The relationship between open space and fire for species in a xeric Florida shrubland. Bulletin of the Torrey Botanical Club 123(2):81-92.

Heywood, V. H. 1978. Flowering Plants of the World. Mayflower Books, New York, N.Y.

Johnson, A. F. 1982. Some demographic characteristics of the Florida rosemary Ceratiola ericoides Michx. American Midland Naturalist 108(1):170-174.

Kral, R. 1960. A Revision of Asimina and Deeringothamnus (Annonaceae). Brittonia 12(4):233-278.

Laessle, A. M. 1965. Spacing and competition in natural stands of sand pine. Ecology 46(1, 2):66-72. 
Menges, E. S., and C. V. Hawkes. Interactive effects of fire and microhabitat on plants of Florida scrub. Ecological Applications. In press.

McCoy, E. D. and H. R. Mushinsky. 1992. Rarity of organisms in the sand pine scrub habitat of Florida. Conservation Biology 6(4):537-548.

Myers, R. L. 1990. Scrub and high pine. In Ecosystems of Florida. R. L Myers and J. J. Ewell (eds.), pp. 150-193. University of Central Florida Press, Orlando.

Murray, N. A. 1993. Revision of Cymbopetalum and Porcelia (Annonaceae). Systematic Botany Monographs 40:1-121.

Nagamitsu, T. and T. Inoue. 1997. Cockroach pollination and breeding system of Uvaria elmeri (Annonaceae) in a lowland mixed-dipterocarp forest in Sarawak. American Journal of Botany 84(2):208-213.

Nadel, H. and J. E. Peña. 1989. Insect pollination of Atemoya in Florida. Florida Entomologist 72(1):207-211.

Nadel, H. and J. E. Peña. 1993. Identity, behavior, and efficacy of nitidulid beetles (Coleoptera: Nitidulidae) pollinating commercial Annona species in Florida. Environmental Entomology 23(4):878-886.

Norman. E. M.,and D. Clayton. 1986. Reproductive biology of two Florida pawpaws: Asimina obovata and A. pygmaea (Annonaceae). Bulletin of the Torrey Botanical Club 113(1):16-22.

Norman, E. M., K. Rice and S. Cochran. 1992. Reproductive biology of Asimina parviflora (Annonaceae). Bulletin the Torrey Botanical Club 119(1):1-5.

Peña, J. E. and F. D. Bennett. 1995. Arthropods associated with Annona spp. in the neotropics. Florida Entomologist 78(2):329-349. 
Peroni, P. A., and W. G. Abrahamson. 1986. Succession in Florida sand ridge vegetation: a retrospective study. Florida Scientist 49(3):176-191.

Richardson, D. R. 1977. Vegetation of the Atlantic Coastal Ridge of Palm Beach County, Florida. Florida Scientist 40:281-329.

Richardson, D. R., and G. B. Williamson. 1988. Allelopathic effects of shrubs of the sand pine scrub on pines and grasses of sandhills. Forest Science 34:592-605.

Schatz, G. E. and A. Le Thomas. 1993. Annonaceae: A primitive dicot family with an ancient center in Africa-South America. In Proceedings of the 37th Annual Systematics Symposium. P. Goldblatt (ed.), pp. 86-104. Missouri Botanical Gardens. Yale University Press, New Haven CN.

Schmalzer, P. A., and C. R. Hinkle. 1992a. Recovery of oak-saw palmetto scrub vegetation. Castanea 57(4):158-173.

Schmalzer, P. A. and C. R. Hinkle. 1992b. Species composition and structure of oak-saw palmetto scrub vegetation. Castanea 57(4):220-251.

Thien, L. B. 1980. Patterns of pollination in the primitive angiosperms. Biotropica 12(1):1-13.

Tietz, H. M. 1973. An Index to the Described Life Histories, Early Stages and Hosts of the Macrolepidoptera of the Continental United States and Canada. A. C. Allyn Publisher. Los Angeles, California.

U. S. Fish and Wildlife Service. 1988. Recovery Plan for three Florida pawpaws. U. S. Fish and Wildlife Service, Atlanta, Georgia.

Webber, A. C. 1992. Pollination. In Maas, P. J. M., L. Y. Th. Westra and Collaborators. Rollinia. Flora Neotropica, Monograph No 1. New York Botanical Garden, Bronx, NY. 
White, R. E. 1983. A Field Guide to the Beetles of North America. Systematic Entomology Laboratory. U.S. Department of Agriculture. Houghton Mifflin, Boston.

Willson, M. F. and D. W. Schemske, 1980. Pollinator limitations, fruit production and floral display in pawpaw (Asimina triloba). Bulletin of the Torrey Botanical Club 107:401-408.

Wunderlin R. P. 1998. Guide to the Vascular Plants of Florida. University Press of Florida. Gainesville, FL. 806 pp. 
Table 1. Flower visitors to Asimina reticulata and $A$. tetramera in sand pine scrub habitat in 1994-96 at JDSP in Martin County and DRP in Palm Beach County, Florida.

\begin{tabular}{|c|c|c|c|c|}
\hline \multirow{3}{*}{$\begin{array}{l}\text { Order } \\
\quad \text { Family } \\
\quad \text { Species } \\
\end{array}$} & \multicolumn{4}{|c|}{ Number of Individuals } \\
\hline & \multicolumn{2}{|c|}{ Asimina reticulata } & \multicolumn{2}{|c|}{ Asimina tetramera } \\
\hline & JDSP & DRP & JDSP & DRP \\
\hline \multicolumn{5}{|l|}{ Blattodea } \\
\hline \multicolumn{5}{|l|}{ Blattellidae } \\
\hline Cariblatta lutea (Saussure \& Zehntner) & 5 & & 4 & 2 \\
\hline \multicolumn{5}{|l|}{ Coleoptera } \\
\hline \multicolumn{5}{|l|}{ Cantharidae } \\
\hline Polemius sp. & 9 & 16 & 1 & \\
\hline \multicolumn{5}{|l|}{ Carabidae } \\
\hline Selenophorus palliatus (Fabricius) & & & & 1 \\
\hline \multicolumn{5}{|l|}{ Cerambycidae } \\
\hline Ancylocera bicolor (Olivier) ++ & & & 1 & \\
\hline Plectromerus dentipes (Olivier) & 3 & & 7 & \\
\hline Typocerus zebra (Olivier) & 31 & & 1 & 1 \\
\hline Zagymnus clerinus (Horn) ++ & & & 4 & \\
\hline \multicolumn{5}{|l|}{ Chrysomelidae } \\
\hline Anomea laticlavia angustata Schaeffer & & & & 1 \\
\hline Bassareus lituratus quinquevittatus & 1 & & & \\
\hline Colaspis sp. & 1 & & & \\
\hline $\begin{array}{l}\text { Neolochmaea dilatipennis Laboissiere } \\
\text { Coccinellidae }\end{array}$ & & & 1 & 1 \\
\hline Harmonia axyridis Pallas & 37 & 1 & & \\
\hline \multicolumn{5}{|l|}{ Curculionidae } \\
\hline Artipus floridanus Horn & 1 & & & \\
\hline Notolomus basalis LeConte & & 8 & 2 & \\
\hline \multicolumn{5}{|l|}{ Lagriidae } \\
\hline Statira dolera Parsons & 1 & & & \\
\hline \multicolumn{5}{|l|}{ Melyridae } \\
\hline Attalus zebraicus Blatchley & 1 & & & \\
\hline \multicolumn{5}{|l|}{ Scarabaeidae } \\
\hline Anomala innuba (Fabricius) & & 1 & & \\
\hline Euphoria limbalis Fall & & & 1 & \\
\hline Euphoria sepulcralis (Fabricius) & 2 & 39 & 3 & 7 \\
\hline Melanocanthon granulifer (Schmidt) & & & 1 & \\
\hline Phyllophaga elizoria Saylor & 9 & & & \\
\hline Phyllophaga latifrons (LeConte) & & & & 1 \\
\hline Trichiotinus rufobrunneus Casey & & & 2 & \\
\hline \multicolumn{5}{|l|}{ Scraptiidae } \\
\hline Allopoda lutea (Haldeman) & 3 & & & \\
\hline \multicolumn{5}{|l|}{ Tenebrionidae } \\
\hline Epitragodes tomentosus (LeConte) & & & & 1 \\
\hline Hymenorus ?tenellus Casey & & 3 & & 13 \\
\hline
\end{tabular}


Table 1. (continued)

\begin{tabular}{|c|c|c|c|c|}
\hline \multirow{3}{*}{$\begin{array}{l}\text { Order } \\
\quad \text { Family } \\
\text { Species } \\
\end{array}$} & \multicolumn{4}{|c|}{ Number of Individuals } \\
\hline & \multicolumn{2}{|c|}{ Asimina reticulata } & \multicolumn{2}{|c|}{ Asimina tetramera } \\
\hline & JDSP & DRP & JDSP & DRP \\
\hline \multicolumn{5}{|l|}{ Diptera } \\
\hline \multicolumn{5}{|l|}{ Bibionidae } \\
\hline Plecia sp. & 1 & 7 & & \\
\hline \multicolumn{5}{|l|}{ Tachinidae } \\
\hline Unidentified sp. & 1 & & & \\
\hline \multicolumn{5}{|l|}{ Hemiptera } \\
\hline \multicolumn{5}{|l|}{ Lygaeidae } \\
\hline Myodochini (nymph) & 1 & & & \\
\hline \multicolumn{5}{|l|}{ Hymenoptera } \\
\hline \multicolumn{5}{|l|}{ Halictidae } \\
\hline Augochlora pura (Say) & 2 & & & \\
\hline Augochlorella sp. & 2 & & & \\
\hline Dialictus sp. & & & 2 & \\
\hline \multicolumn{5}{|l|}{ Lepidoptera } \\
\hline \multicolumn{5}{|l|}{ Noctuidae } \\
\hline Unidentified sp. + & & & 2 & \\
\hline \multicolumn{5}{|l|}{ Papilionidae } \\
\hline Eurytides marcellus (Cramer) & 10 & 10 & 17 & 7 \\
\hline \multicolumn{5}{|l|}{ Pyralidae } \\
\hline \multirow[t]{2}{*}{ Omphalocera sp. +} & $13^{* \star}$ & 1 & $12^{++}$ & \\
\hline & 134 & 86 & 61 & 35 \\
\hline \multicolumn{5}{|c|}{$\begin{array}{l}\text { + Specimens are in larval stage. } \\
++ \text { Collected in } 1996 \text { after prescribed fire }\end{array}$} \\
\hline beetles & 99 & 68 & 24 & 26 \\
\hline
\end{tabular}




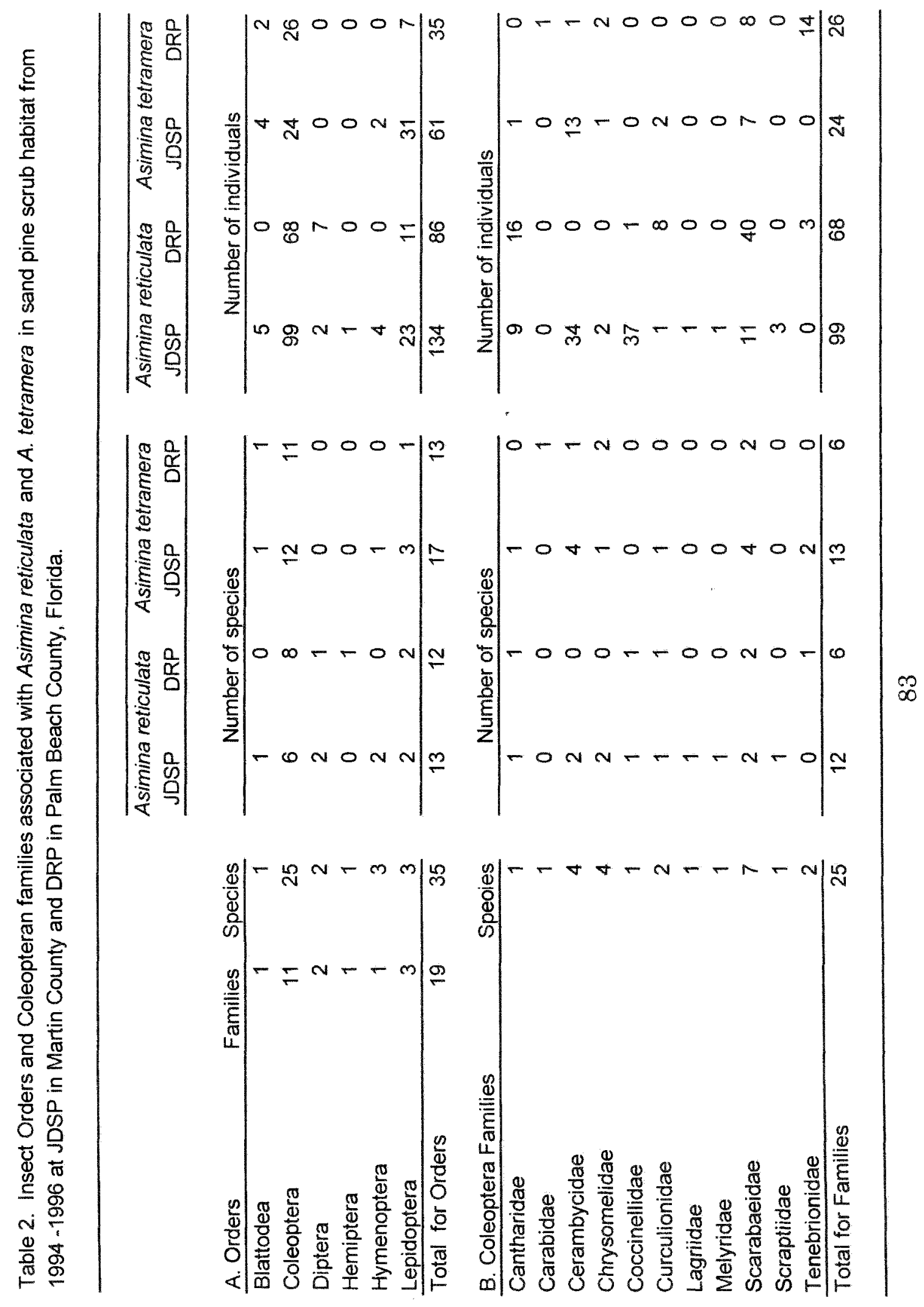




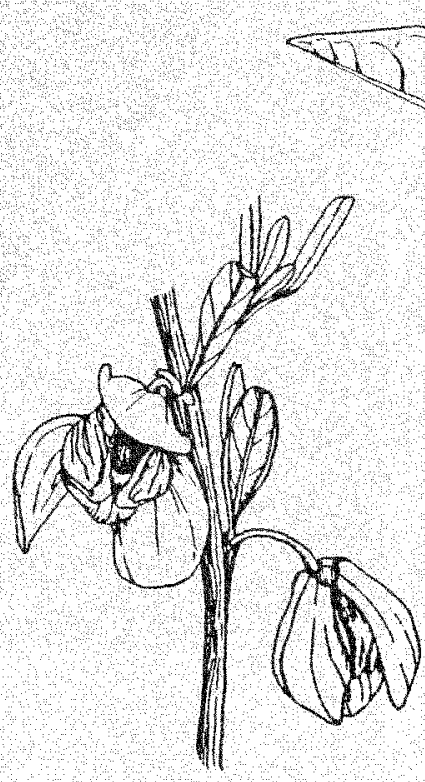

Asimina reticulata

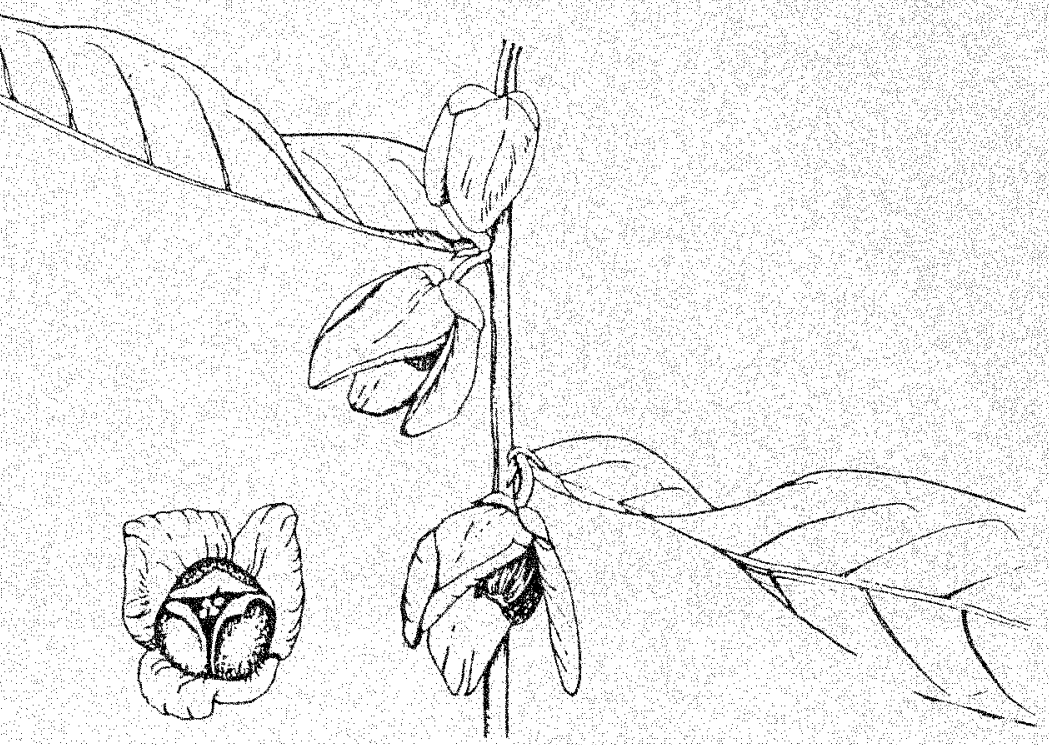

Asimina tetramera

Figure 1. Open Asimina reticulata and $A$. tetramera flowers. Line drawings by Ann Murray. 

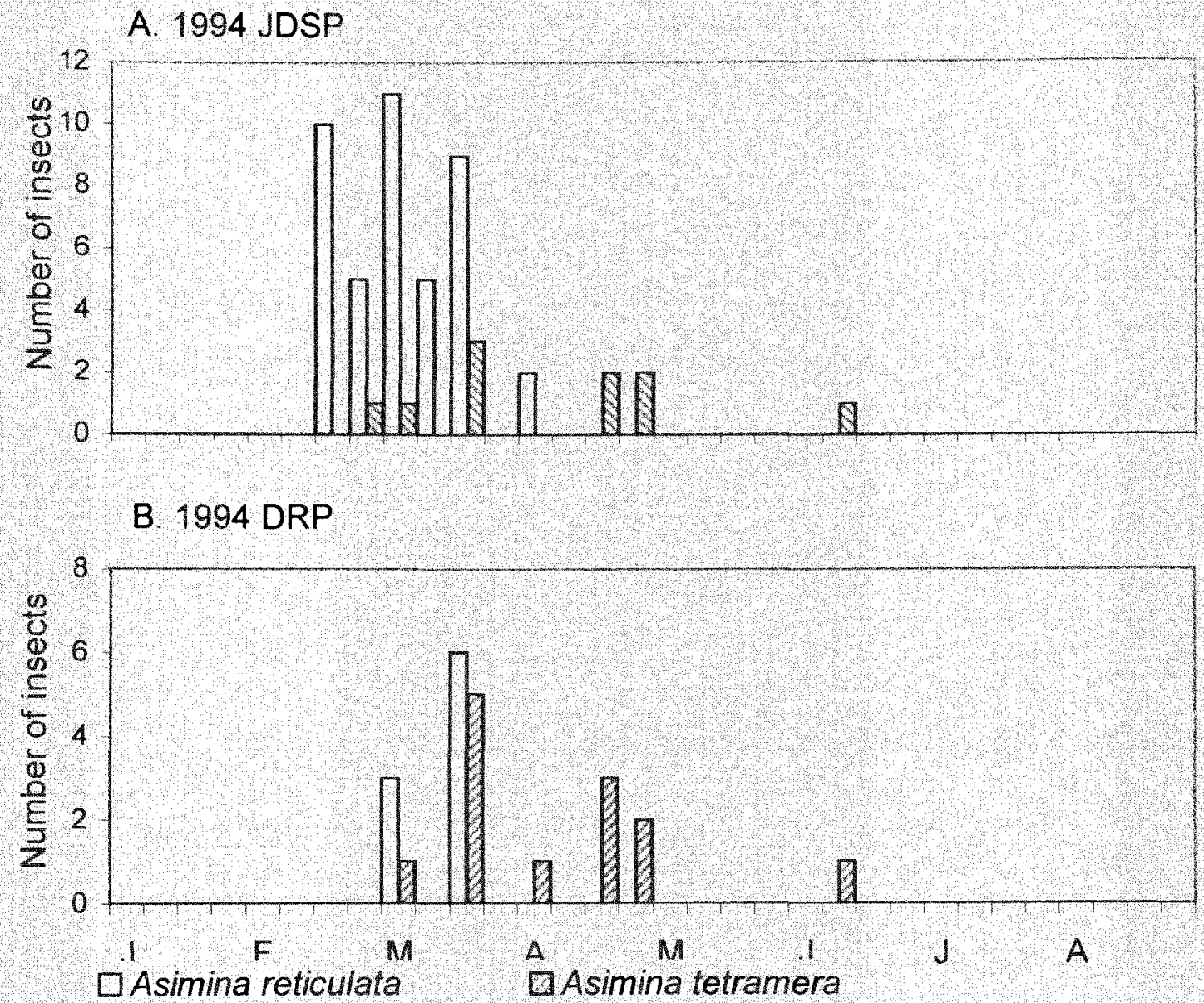

Figure 2. Insect visitor frequency to Asimina flowers during 1994 flowering season. (A) Jonathan Dickinson State Park (JDSP) and (B) DiamondheadRadnor (DRP). Flower data were not collected in 1994. 

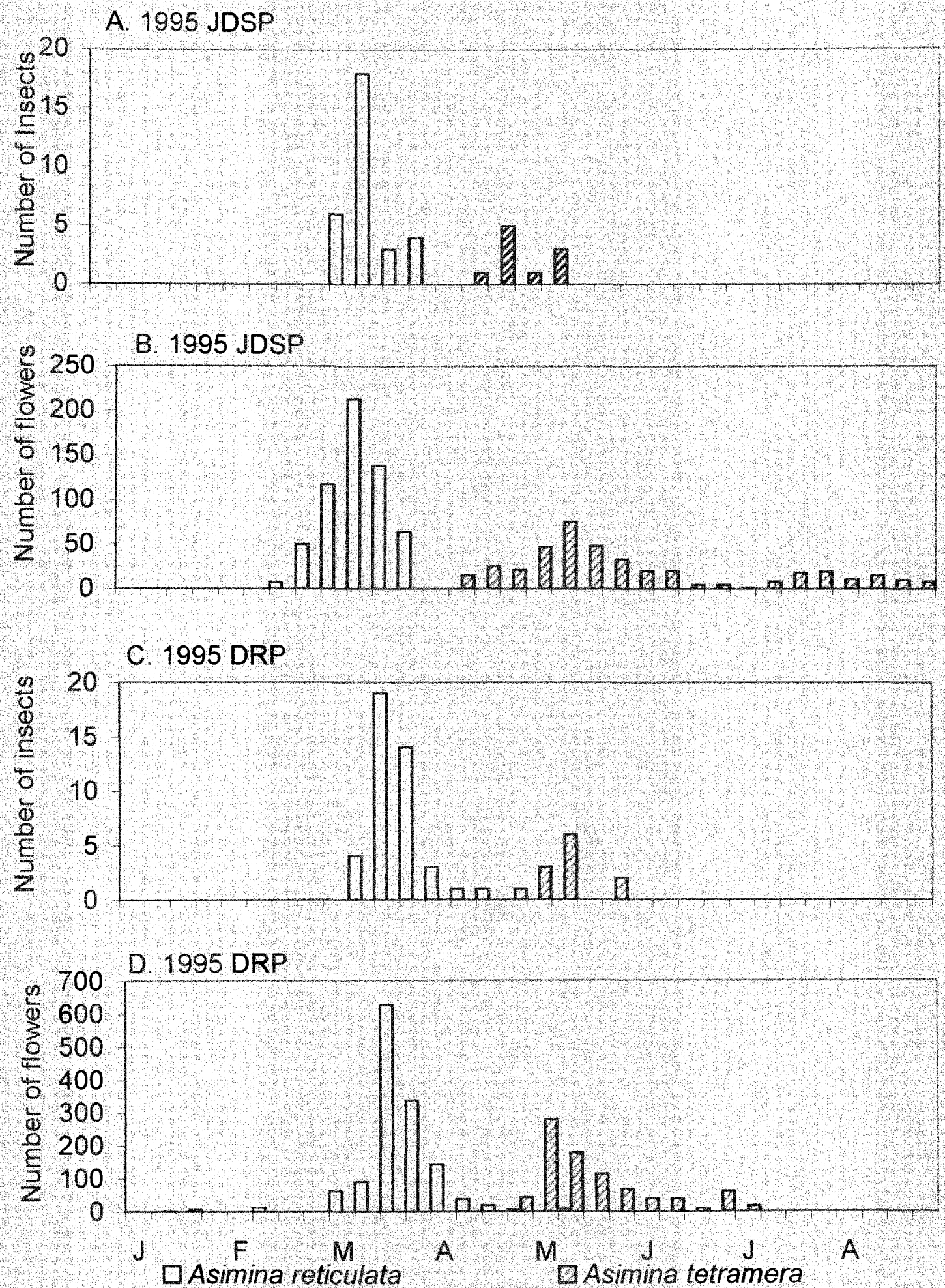

Figure 3. Insect visitor and flower frequency to Asimina during 1995 flowering season. Abbreviations as in Fig. 2. Note: scales for insects and flowers differ. 

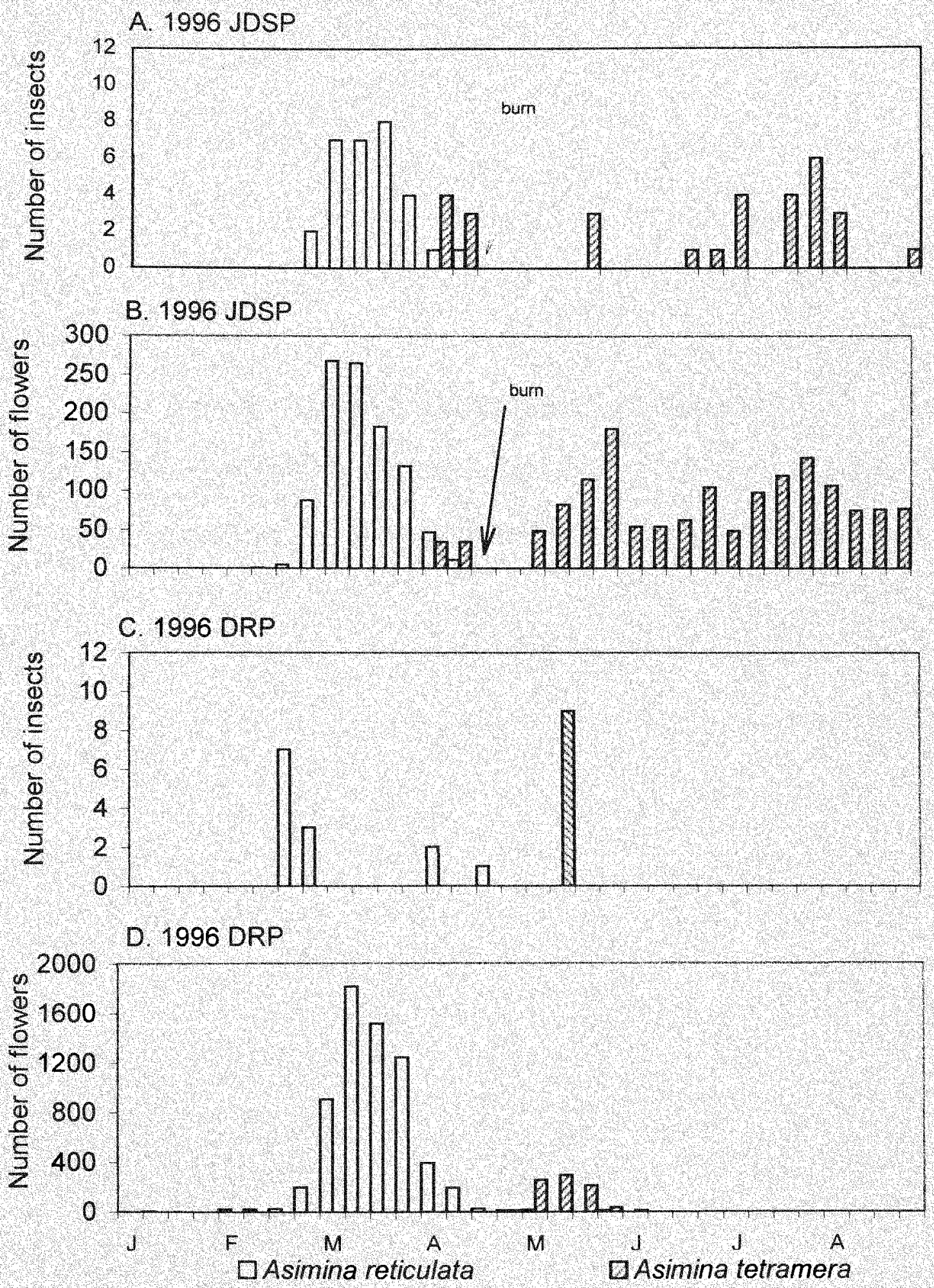

Figure 4. Insect visitor and flower frequency to Asimina during 1996 flowering season. Abbreviations as in Fig. 2. Note: scales for insects and flowers differ. 
EFFECTS OF PRESCRIBED MANAGEMENT

ON THE FOUR-PETAL PAWPAW, ASIMINA TETRAMERA SMALL (ANNONACEAE), AN ENDANGERED SPECIES IN FLORIDA 
Effects of prescribed management on the four-petal pawpaw Asimina tetramera Small (Annonaceae), an endangered species in Florida

\begin{abstract}
Mechanical cutting and fire in combination were used to test the flowering and fruiting response of Asimina tetramera to various management techniques in sand pine scrub habitat. This federally endangered species, limited to two counties in southeastern Florida, showed reduced flowering and fruiting under a closed canopy of sand pine (Pinus clausa). The results of this 1994-1996 study show that significantly higher percentages of plants flowered in the BURN and CUT\&BURN treatments one year post-treatment than in the MULCHED, HAND.CUT and the CONTROL. Weighted least squares analysis for number of plants that set fruit showed a significant difference among years, but there was no difference among treatments. This study shows that flowering and fruiting can be stimulated by burning a mature habitat in the spring with no loss of individual plants. Habitat management will be required at some point for the remaining populations of A.tetramera in the small scrub habitats on the Atlantic Coastal Ridge. The life history traits are just now being examined for $A$. tetramera. Critical life history stages may be seed dispersal and germination. If scrub is burned before recruitment occurs, we may only be able to maintain present populations.
\end{abstract}

Key words: Asimina tetramera, endangered species, pawpaw, prescribed burn, resource management, sand pine scrub, Florida. 


\section{INTRODUCTION}

Asimina tetramera Small (1926), the four petal pawpaw, is a federally endangered species (USFWS 1988) endemic to scrub habitat in southern Florida. This small shrub, in the predominantly tropical Annonaceae, is restricted to the sands of Pleistocene dunes in Martin and Palm Beach Counties (Kral 1960). A survey was conducted by Florida Natural Areas Inventory in 1988 to assess the plant's status in response to the USFWS Pawpaw Recovery Plan (1988). The survey found 16 sites with 742 individual plants, indicating that the population was larger than the 100 individuals formerly known to exist on three sites (Austin and Tatje 1979). Present population estimates are closer to 1000 individuals, with approximately 300 plants on six sites in Martin County and 700 plants on 10 sites in Palm Beach County (Cox unpublished data). Local population sizes range from 2 to 225 individuals (Farnsworth 1988).

Asimina tetramera is an aromatic shrub one to two meters tall, with one to several stems arising from the crown of the deep root that extends several meters into the sand. Cutting and burning stimulate shoot development from the below-ground crown (Kral 1960, USFWS 1988). The deciduous plants break dormancy in March and mature plants produce flowers in the axils of developing shoots. The flowers have three perianth whorls of three or four tepals and turn dark maroon when mature. Flowers are protogynous; and one to nine individual carpels may develop from a 
single flower. These carpels are collectively known as a baccetum according to Spjut's (1994) fruit type classification.

Plants in open, sunny sites typically produce more flowers and fruit than plants in shady locations (Kral 1960, Farnsworth 1988). The increased flower numbers in sunny locations provide more flowers receptive to pollination when others are producing pollen, and attract more pollinators to the plants. Few A. tetramera flower under closed canopies of mature sand pine (Farnsworth 1988, Cox personal observation). Other factors contributing to reproductive decline in mature scrub include: low plant vigor, few flowers per plant, few plants in flower at one time for crosspollination, reduced availability of pollinators, and competition from other species. In mature plants, stems become progressively smaller each year until the stem diameters become too small to bear fruit (Cox personal observation).

Asimina tetramera produces vigorous shoots from the below-ground stems after burning or cutting (Kral 1960, Austin and Tatje 1979, Kral 1983). Within 6-10 weeks, adult plants produce numerous flowers on the rejuvenated stems (Burns 1987, Moyroud 1988). Related species, $A$.

angustifolia Raf. and A. pygmaea (Bartr.) Dunal, seldom flowered in longleaf pine forests except in response to fire (Kral 1960). Chopping the vegetation without raking, and cutting the understory shrubs to sandy soil reduces competition and encourages recruitment into open areas (Kral 1983). 
Helkowski and Norman (1997) tested the effects of hand-clipping and fire on a closely related species, Deeringothamnus rugelii B. L. Robins., an endangered small shrub of pine flatwoods in eastern Central Florida. Stem production, flowering, and fruit-set increased in the clipped and burned treatments, but an increase in flowering did not occur the following season (Helkowski and Norman 1997).

The USFWS Pawpaw Recovery Plan (1988) stated the need for scrub habitat management through prescribed burning, brush control, or mowing to remove competing vegetation and to recycle nutrients needed for flowering and fruiting. Although A. tetramera is reported to respond to disturbance regimes of occasional fire or hurricane damage (Kral 1960, Austin and Tatje 1979, Kral 1983, USFWS 1988), data are not available and methodology has not been developed (USFWS 1988).

Asimina tetramera showed reduced flowering and fruiting under the closed canopy of mature sand pine habitat that had not been burned for at least 50 years. The purpose of this research was to quantify and compare the effects of prescribed burning and various chopping techniques on flowering and fruiting of $A$. tetramera. Vigorous vegetative and reproductive response from cutting, fire, and other disturbances indicates that plants may require removal of competing vegetation (Cox personal observation). In shrublands, fire increases flowering in some species and may be required for flowering (Christensen 1985). To determine whether fire and mechanical cutting elicit 
similar flowering and fruiting response in A.tetramera, I applied two combinations of fire and two mechanical treatments in late spring of 1996. As sand pine scrub typically burns intensively and unpredictably, alternatives to burning may be required to manage the small remaining fragments of scrub habitat on the Atlantic Coastal Ridge. Cutting and removal of vegetation or mulching may elicit a similar reproductive response to burning for $A$. tetramera. The results of this study provide information for the development of appropriate management procedures in scrub habitat for A. tetramera in sand pine scrub habitat.

\section{METHODS}

\section{Study Site}

The study site in Jonathan Dickinson State Park (JDSP, Martin County) is $8 \mathrm{~km}$ north of the town of Jupiter, Florida $\left(27^{\circ} 00^{\prime} \mathrm{N}, 80^{\circ} 06^{\prime} \mathrm{W}\right)$. The JDSP sand pine scrub habitat is the largest remaining parcel of coastal scrub (853 hectares) on the Atlantic Coastal Ridge (Fernald 1989). The mature sand pine scrub has three layers: a sand pine (Pinus clausa (Chapm. ex Engelm.) Vasey ex Sarg.) canopy, an oak shrub understory, and a sparse herb and graminoid layer. The dense sand pines (330 trees/hectare) form a closed canopy ( $86.5 \%)$ with occasional gaps created by fallen trees from senescent pines $(\bar{x}=48, \pm 12.4$ yrs, maximum age 79 yrs from tree ring cores in 1995). The shrub understory includes oaks (Quercus geminata Small, $Q$. 
chapmanii Sarg., and Q. myrtifolia Willd.), Florida rosemary (Ceratiola ericoides Michx.), staggerbush (Lyonia fruticosa (Michx.) Torr.), wax myrtle (Myrica cerifera L.), saw palmetto (Serenoa repens (Bartr.) Small), and pawpaws (A. reticulata Chapm. and A. tetramera). A thick litter layer (4-10 $\mathrm{cm}$ ) accumulates under the mature pines. Open sandy areas are sparse and often covered by lichens (Cladonia Wigg.). Signs of past disturbance are barely perceptible, although Camp Murphy, an Army Radar Training Center, occupied the area in the early 1940's and remnants of old foundations remain on the site. The effects of pineapple farming in the late 1920's are not evident, except for the absence of saw palmettos in one area.

Scrub ridge soils are sandy entisols, or Psamments in the Paola series. These are excessively well-drained, thick sands low in nutrients (USDA 1978). Elevations on the site range from 11 meters (NGVD) on the crest of the dune to 4.5 meters at the lowest point west of the ridge. The climate is subtropical, characterized by hot, wet summers and mild, dry winters (Winsberg 1990). Temperatures recorded from 1989 to 1993 ranged from an average high of $28^{\circ} \mathrm{C}$ to an average low of $19^{\circ} \mathrm{C}$. The mean annual rainfall is $151 \mathrm{~cm}$, with $57 \%$ of the rainfall occurring from June to November (JDSP weather station unpublished data).

The sand pine scrub research site (Fig. 1) is located on the southern portion of the primary dune ridge, north of the main park entrance. The 4.05 hectares study site extends north from the entrance station, between 
Park Drive on the west and the Florida Trail on the east. A 25 meter wide strip along Park Drive was mowed for a fire break.

\section{Site Preparation}

The 4.05 hectare site was divided into 14 treatment areas $(0.3 \mathrm{ha})$ in 1995 (Fig. 1). Areas were assigned the following treatments: 1) vegetation left intact and burned [BURN]; 2) shrubs and small trees cut to $40 \mathrm{~cm}$ with a mechanical cutter, allowed to dry, and burned [CUT\&BURN]; 3) all shrubs and small trees were chopped and left as mulched biomass and not burned [MULCHED]; 4) understory vegetation hand cut, removed and not burned [HAND-CUT] and 5) natural vegetation left intact [CONTROL]). Three areas were assigned per treatment except the HAND-CUT treatment, originally designed as firebreaks. The BURN and CUT\&BURN areas were placed adjacent to each other for fire control purposes; the other three areas were randomly assigned.

Areas to be cut (CUT\&BURN, MULCHED, and HAND-CUT) were prepared in mid-April 1996. Approximately 10-15 days were required without rain for the cut fuels to dry out and reduce the fuel moisture for burning. Local weather conditions (wind speed, wind direction, relative humidity, cloud cover) and fuel moisture levels $(1 \mathrm{hr}, 10 \mathrm{hr}, 100 \mathrm{hr}$ dead fuel and live fuel moisture) were monitored for the prescribed conditions for burning. The fire was set on May 17, 1996, the first day that the local weather conditions were within the prescribed range. The BURN areas were started first using 
backing fires and then strip fires were set into the prevailing wind. The CUT\&BURN areas were ignited last.

\section{Study Species}

I tagged and numbered 157 A. tetramera plants in 1994, and monitored shoot, leaf, and flower development each spring following winter dormancy from 1994 to 1996 . I counted buds, open flowers, and fruit weekly from February through August in 1994 and 1995 and until December in 1996. Flowers were considered open when the outer petals elongated, the inner petal color changed from green to maroon, and the stigmas glistened. Fruit that remained on the plants for at least six weeks were counted as mature.

\section{Statistical Analysis}

Data were analyzed using multidimensional contingency analysis (SAS CATMOD). Weighted least squares analyses (four treatment areas and a control by three years) were run using Chi-square tests to develop a model to predict the proportion of $A$. tetramera plants that flowered and the proportion that set fruit. Full models were fit to test for interaction. If significant, further analyses were conducted to see if there were: differences in percent flowering (fruiting) among treatment areas within years, and differences in percent flowering (fruiting) among years within treatment areas. For significant treatment within year differences, treatment areas were contrasted to the control. For significant year within treatment 
differences, 1994 and 1995 (pre-treatments) were compared to 1996 (posttreatments). Non-significant effects were eliminated from the full models. Final models with only significant effects were built, with an additional goodness of fit test based on the residuals. All tests were considered significant at the $\mathrm{p} \leq 0.05$ level. Data for fruit were transformed by adding 0.5 to all values and the model was run on the adjusted response frequencies because of the large number of zeros in the data set (Table 3A) (Tabachnick and Fidell 1989).

\section{RESULTS}

The prescribed burn killed most of the sand pines and the above ground portions of shrubs and herbs within the BURN and CUT\&BURN treatments. Few pines were killed by the MULCHED or HAND-CUT treatments, although some pines in the HAND-CUT areas adjacent to the fire were killed by the intense heat. The fire in the CUT\&BURN reduced the vegetation to mineral soil, leaving only areas of bare sand unburned. The fire in the BURN was "patchy" as small areas of vegetation (ca. five meters square) did not burn. Several pines within these unburned patches survived. Above-ground portions of $A$. tetramera plants in the BURN and CUT\&BURN areas were burned and $A$. tetramera stems in the MULCHED and HAND-CUT areas were razed.

Following winter dormancy, A. tetramera developed new shoots, 
leaves, and adult plants produced flower buds starting in late February. The first flowers opened in mid-March, flowering peaked the first week in May, and continued for 19 weeks until mid-August (Fig. 2A). Flowering in the CONTROL $(n=43)$ followed trends similar to the whole population $(n=157)$ in 1995 except that flowering continued 15 weeks in 1995 (Fig. 2B) and 12 weeks in 1996 (Fig. 2C). The maximum percentage of plants flowering at any one time during the season was $13.4 \%$ (population 1995), $13.4 \%$ (CONTROL 1995) and 23.5\% (CONTROL 1996) (Fig. 2A, B). Flowering duration for individual plants in the population varied from one to six weeks and the average time plants were in flower was $2.5( \pm 2.2)$ weeks in 1995 and 2.8, ( \pm 2.8) in 1996.

For the entire year in $1995,23 \%$ of the total plants in the population $(n=157)$ bloomed. The percentage of plants blooming in the CONTROL areas were similar: $27.8 \%$ in $1994,23.3 \%$ in 1995 and $27.9 \%$ in 1996 (Fig. 2B). Fruiting followed two to three weeks after flowers opened and fruit began to set a week earlier in 1996 than in 1995. Fruit remained on the plants from 7 to 14 weeks $(\bar{x}=11.4, \pm 3.6)$ before ripening in mid August in 1994 and 1995 . The plants that flowered early during the first two weeks or late after midJuly did not set fruit in 1995.

Asimina tetramera bud development and flowering was interrupted in mid-April in 1996 in the CUT\&BURN, MULCHED, and HAND-CUT areas (Figs. 3B, C, D) when the understory was cut. Growth was also interrupted in mid- 
May, by fire in the BURN and CUT\&BURN areas (Fig. 3A, B). Of the 157 plants in the study, all 114 plants in the treatment units survived the cutting and burning treatments. In all treatment areas, the number of plants producing flowers increased (Table 1A). A total of 29 more plants produced flowers after the treatments, with the highest number in the CUT\&BURN, an increase of 19 plants from 1994. Plants producing fruit also increased from pretreatment years with 29 more plants setting fruit (Table 1B).

Asimina tetramera individuals varied in sprouting, flower initiation, flower numbers and number of fruit in the management areas. Sprouting and flowering initiation was sporadic throughout the summer, with the last plant sending up shoots and beginning to flower as late as September. Unlike 1994 and 1995 when flowering stopped in August, flowering, pollination and fruit production continued through December in the CUT\&BURN areas. Peak flowering occurred at different times for each treatment. To illustrate the variation in flowering patterns, two plants are represented from each treatment and the CONTROL, showing the extreme and typical flowering patterns (Figs. 4A-E). In all management areas in 1996, the duration of flowering and fruit-set extended beyond the season exhibited in 1995 and the CONTROL in 1996.

The full model to test for treatment by year interaction was significant for flowering (Table 3A, Fig. 5A). An examination of treatment areas within years showed no statistically significant differences in percent flowering 
among the areas in $1994(\mathrm{p}=0.836)$ and $1995(\mathrm{p}=0.851)$ before treatments were applied (Table 2B). However, the percent of plants that flowered after management treatments in 1996 differed significantly (Table 2B). Contrasts between the treatments revealed that the percent of plants flowering in the CUT\&BURN (65.3\%) was significantly higher from that in the CONTROL $(27.9 \%$, Table 2C). No other significant differences were observed in percent of plants flowering among the treatments and the CONTROL.

A final model was constructed containing a main effect of year and treatment within year for 1996, and both main effects were significantly different (Table 2D). An examination of years within treatment found no significant differences in percent of plants flowering for three of the treatment areas: MULCHED, HAND-CUT and the CONTROL (Table 2E). However, in the CUT\&BURN, two years showed a significant difference. The percent of flowering plants in CUT\&BURN was significantly higher in 1996 (65.3\%) than in both $1994(26.5 \%)$ and 1995 (18.37\%) (Table 2F). In the BURN area, there was a marginally significant increase in flowering from $25.0 \%$ in 1995 to $53.6 \%$ in 1996 (Table $2 \mathrm{~F}$ ). A final model was constructed containing the main effect of treatment and year nested within treatment areas for BURN and CUT\&BURN areas. The goodness of fit test was nonsignificant, indicating that the model fit (Table 2G).

For fruit, the full model was significant for years (Table 3A, Fig. 5B). The percent of plants that set fruit differed significantly from 1994 and 1995 
to 1996 (Table 3B). Although the percent of plants setting fruit increased in 1996 after all management treatments were applied, the sample sizes were small, and significant changes were difficult to detect (Fig. 5). No significant interaction occurred between treatment and year.

\section{DISCUSSION}

Asimina tetramera sprouted vigorously after the burn and mechanical treatments among the slowly resprouting oaks. Within two weeks of the May 17th burn, summer rain started, assisting with plant growth and regeneration. The fire left unburned patches in the BURN area, providing seed sources for species killed by the fire. The heterogeneity of the scrub, maintained by infrequent fires that tend to burn unevenly, was duplicated in the small areas of this study.

Flowering Response to Fire

Asimina tetramera in the BURN and CUT\&BURN areas increased flowering significantly compared to the two years prior to management (Table 2). This finding was expected since $A$. tetramera previously responded both vegetatively and reproductively with new growth after fire (Kral 1960). Two other species, A. longifolia and A. pygmaea, respond similarly. However, they seldom flower unless the long-leaf pine forest they inhabit is burned. Fire stimulates flowering in some scrub species (Abrahamson 1984, Ostertag and Menges 1994, Lambert and Menges 1996). 


\section{Flowering Response to Cutting}

The low percentages of plants flowering in the MULCHED and HAND-CUT areas (Table 1) were not expected, as cutting is reported to stimulate shoot development and flowering (Kral 1960, 1983). Many plants produced renewal shoots in response to the cutting treatments, but did not flower. It is possible that non-reproductive plants were young and may have had only sufficient underground storage reserves for sprouting, but not for flowering. Plants that flowered after treatments were those that flowered in 1994 and 1995. Although Kral (1960) indicated that disturbance enhanced flowering in Deeringothamnus rugelii, plants that were clipped at ground level did not show significant differences in flowering from a control (Helkowski and Norman 1997).

\section{Flowering in the Control}

The overall percentage of flowering plants in the CONTROL was not different between $1994(27.3 \%), 1995$ (23.3\%), and $1996(27.9 \%)$. As the plants mature, the growing stems become smaller each year and produced fewer flowers; many of these mature plants flower, but do not produce fruit (Cox unpublished data). Willson and Schemske (1980) also found that flowers were not produced on small branches (less that $1.8 \mathrm{~cm}$ diameter) in $A$. triloba. Fewer flowers per plant and the low number of individuals flowering in the mature habitat may have limited pollinator movement between plants. In the absence of fire or major disturbance, diminished flowering and fruit- 
set may cause a shift from sexual reproduction to vegetative reproduction (Lambert and Menges 1996). The slight increases in flowering in areas before management and in the CONTROL after management could be attributed to sand pine senescence and tree falls. As sand pines reach maturity at 50-70 yrs, gaps form in the canopy from fallen pines to create small disturbances in the understory. Between 1995 and 1996 several mature pines fell on A. tetramera, stimulating renewal shoots and promoting flowering.

\section{Effects of Season of Burn}

The CUT\&BURN and BURN treatments were implemented in mid-May 1996 during the early growing season. This is during the historic wildfire season (March-June) when the majority of lightning or human-caused fires burn the greatest acreage (Robbins and Myers 1989). Season of burn influences the flowering and fruit-set in many scrub resprouting shrubs and herbaceous species (Abrahamson 1984). Asimina tetramera burned in late February, flowered in April, during the typical flowering season (Cox personal observation). Plants burned in August at Carlin Park in Palm Beach County (not included in this study), flowered in October, but did not set fruit (Cox personal observation). Incidence of flowering and seed set is higher after late spring and summer fires than in winter fires for many woody resprouting scrub species (Abrahamson 1984). April, May or June fires stimulate flowering in several grasses including cutthroat grass 
(Panicum abscissum) and beardgrasses (Andropogon spp.); these species respond vegetatively to winter fires (Abrahamson 1984).

The flowering season was extended in all the treatment areas after management applications (Figs. 3, 4). The increase in the number of plants flowering assures synchronization, thus promoting outcrossing. Asimina tetramera is self-incompatible and requires cross-pollination to set viable seed (See Chapter I). The likelihood that insects will move pollen from flower to flower (geitonogamy) on the same plant increases as the number of flowers per plant increases (Barrett et al. 1994). Plants with few flowers in 1994 and 1995 produced more flowers in 1996 after the BURN and CUT\&BURN treatments. Fewer flowers per plant and low numbers of flowers produced at the beginning of the season encourage pollination between plants. However, if blooming plants are far apart, cross-pollination may not take place and fruit may not set when flower numbers are too low.

\section{Fruit Response}

Few $A$. tetramera plants in the mature scrub habitat produced fruit in $1994(4.5 \%)$ and 1995 (9.5\%). Significantly more fruit $\left(\chi^{2}=13.51, \mathrm{df}=2\right.$, $\mathrm{P}<0.001)$ were produced in 1996 after both burning and cutting treatments (Table 3A). The increase in fruit production may also be attributed to decreased competition, increased light intensity, nutrient recycling, and increase in pollinator activity as a result of flowering. The increase in flowering may also attract insects from adjacent open habitats. The primary 
pollinators of $A$. tetramera are beetles, many of which are generalist pollinators and are attracted by fruity scent of the flowers (See Chapter II). Euphoria sepulchralis (Fabricus) (Scarabaeidae) and Typocerus zebra (Olivier) (Cerambycidae) visit $A$. tetramera at; as well as other flowering species in JDSP.

The percent of plants setting fruit were highest in the BURN (39\%) and CUT\&BURN (34.7\%) treatment areas. Flowering also increased in these areas. Fruiting also increased in MULCHED (28.6\%) and HAND-CUT (30.4\%), but the four treatments were not statistically different (Fig. 5 B, Table 3A).

\section{Survival after Management}

All $114 A$. tetramera responded to treatments by sprouting renewal shoots from underground structures. Asimina tetramera's response to fire is similar to the "fire-persister" species in California chaparral that exhibit resilience to fire (Keeley 1989). Despite renewed vigor from underground stems or roots after fire, and production of multiple stems from the rootcrown, they do not produce vegetative clones like $A$. triloba (Willson and Schemske 1980) and many dominant shrubs of scrubby flatwoods (Menges and Kohfeldt 1995).

Asimina tetramera also remains in the habitat, in contrast to previous assumptions that these plants succumb to competition from dense oaks in the understory. These plants may live for hundreds of years, similar to many sprouting shrubs that owe their longevity to extensive underground parts 
(Abrahamson 1984). In 1993, an extensive survey of this site added 114 plants to the original 43 known to exist in 1988. Seventy-three plants were added to the 157 existing plants after treatments in 1996 . These plants persisted at low activity levels in dense oak and saw palmetto thickets in the mature habitat until the understory was removed. This increased the JDSP population to 230 plants, the largest known population at present. 


\section{LITERATURE CITED}

Abrahamson, W. G. 1984. Species responses to fire on the Lake Wales Ridge. American Journal of Botany 71(1):35-44.

Austin, D. F. and B. E. Tatje. 1979. Endangered Four-petal Pawpaw. In, Rare and Endangered Biota of Florida. Volume 5 Plants. D. B. Ward (ed.), pp. 5-6. University Presses of Florida.

Barrett, S. C. H., L. D. Harder, and W. W. Cole. 1994. Effects of flower number and position on self- fertilization in experimental populations of Eichhornia paniculata (Pontederiaceae). Functional Ecology 8:526535 .

Burns, R., Assistant Director, Nature Conservancy. 1987. [Letter to Richard Moyroud]. A proposal for cooperative management and registry. September 3 .

Christensen, N. L. 1985. Shrubland fire regimes and their evolutionary consequences. In The Ecology of Natural Disturbance and Patch Dynamics. S. T. A. Pickett and P. S. White, (eds), pp. 86-100. Orlando Florida: Academic Press.

Farnsworth, S. 1988. Summary Four-Petal Pawpaw Report. Florida Natural Areas Inventory, Nature Conservancy. Unpublished report.

Fernald, Raymond T. 1989. Coastal Xeric Scrub Communities of the Treasure Coast Region, Florida; A summary of their distribution and ecology, with guidelines for their preservation and management. Florida Game and Fresh Water Fish Commission, Nongame Wildlife Program Technical Report No 6. Tallahassee, FL. 125 pp.

Florida Natural Areas Inventory. 1988. Four-petal Pawpaw Survey. The Nature Conservancy and The Florida Department of Natural Resources. 
Helkowski, J. H. and E. M. Norman. 1997. Effects of fire on an endangered plant, Deeringothamnus rugelii. Florida Scientist 60(2):118-123.

Keeley, J. E. 1989. Resilience to fire does not imply adaptation to fire: and example from the California chaparral. In Proceedings 17th Tall Timbers Fire Ecology Conference, pp. 113-119. Tallahassee. Florida.

Kral, R. 1960. A Revision of Asimina and Deeringothamnus (Annonaceae). Brittonia 12(4):233-278.

Kral, R. 1983. A Report on Some Rare, Threatened, or Endangered ForestRelated Vascular Plants of the South. Vol. I. TE Pub. R8-TP 2. USDA Forest Service Southern Region.

Lambert, B. B. and E. S. Menges. 1996. The effects of light, soil disturbance and presence of organic litter on the field germination and survival of the Florida golden aster, Chrysopsis floridana Small. Florida Scientist 59(2):121-137.

Menges, E. S. and N. Kohfeldt. 1995. Life history strategies of Florida scrub plants in relation to fire. Bulletin of the Torrey Botanical Society 122(4):282-297.

Moyroud, R. 1988. [Report on Asimina tetramera propagation under nursery conditions to Susan Wallace, Curator of Endangered Species, Bok Tower Garden]. 5 January 1988.

Ostertag, R. and E.S. Menges. 1994. Patterns of reproductive effort: time since last fire in Florida scrub plants. Journal of Vegetation Science 5:176-192.

Robbins, L. E. and R. L. Myers. 1989. Seasonal effects of prescribed burning in Florida: A review. The Nature Conservancy Fire Management and Research Program, Tallahassee, Florida. 
Small, J. K. 1926. A new pawpaw from Florida. Torreya 26:56.

Spjut, R. W. 1994. A Systematic Treatment of Fruit Types, Memoirs of the New York Botanical Garden 70.

Tabachnick, B. G. and L. S. Fidell. 1989. Using Multivariate Statistics. Harper Collins. California State University, Northridge.

United States Department of Agriculture. 1978. A Soil Survey of Palm Beach County Area, Florida. Washington, D. C. 96 pp +160 maps.

U. S. Fish and Wildlife Service. 1988. Recovery Plan for three Florida pawpaws. U.S. Fish and Wildlife Service, Atlanta, Georgia. 20 pp.

Willson, M. F. and D. W. Schemske. 1980. Pollination limitation, fruit production, and floral display in pawpaw (Asimina triloba). Bulletin of the Torrey Botanical Club 107(3):401-408.

Winsberg, M. D. 1990. Florida Weather. University of Florida Press 
Table 1. Percent Asimina tetramera flowering and setting fruit in four resource management areas and CONTROL from 1994 - 1996. Management techniques were applied in May 1996. Post-treatment data are for 1996.

\begin{tabular}{|c|c|c|c|c|c|}
\hline Area: & Burn & Cut\&Burn & Mulched & Hand-cut & Control \\
\hline \multirow[t]{2}{*}{$\mathrm{N}:$} & 28 & 49 & 14 & 23 & 43 \\
\hline & $\%$ & $\%$ & $\%$ & $\mathrm{n}$ & $\%$ \\
\hline
\end{tabular}

\section{A) FLOWERING}

Pre-treatment

1994

$\begin{array}{llllllllll}28.6 & 8 & 26.5 & 13 & 21.4 & 3 & 17.4 & 4 & 27.9 & 12\end{array}$

1995

$\begin{array}{llllllllll}25.0 & 7 & 18.4 & 9 & 21.4 & 3 & 30.4 & 7 & 23.3 & 10\end{array}$

Post-treatment

1996

$\begin{array}{llllllllll}53.6 & 15 & 65.3 & 32 & 28.6 & 4 & 34.8 & 8 & 27.9 & 12\end{array}$

B) FRUIT

Pre-treatment

1994

3.61

6.13

$0.0 \quad 0$

$\begin{array}{llll}0.0 & 0 & 7.0 & 3\end{array}$

1995

$\begin{array}{llll}14.3 & 4 & 8.2 & 4\end{array}$

0.00

$\begin{array}{llll}8.7 & 2 & 11.6 & 5\end{array}$

Post-treatment 1996

$\begin{array}{llllllllll}39.3 & 11 & 34.7 & 17 & 28.6 & 4 & 30.4 & 7 & 16.3 & 7\end{array}$ 
Table 2. Summary of models for percent plants flowering in four treatment areas and CONTROL from $1994-1996 .{ }^{*}=$ significant at $P<0.05$.

Source

df

$x^{2}$

$\mathbf{P}$

A. Full Model: treatment areas and years

Treatment areas

4

6.48

0.166

Years

Treatment areas $x$ years

2

8

13.51

16.66

$0.001^{*}$

$0.034^{*}$

B. Treatment areas within year

Treatment areas (1994)

Treatment areas (1995)

Treatment areas (1996)
4

1.45

1.36

18.87

4
0.836

0.851
$0.001^{*}$

C. Treatment areas compared to the CONTROL in 1996

Treatment area (BURN)

Treatment area (CUT\&BURN)

Treatment area (MULCHED)

Treatment area (HAND-CUT)
4
4
4
4

1.89

0.169

12.10

1.73

$0.001^{*}$

0.188

0.69

0.407

D. Final Model: years and treatments area within year for 1996 .

Years

Treatment areas

Residual
2

4

8
15.07

18.87

2.81

E. Years within treatment areas for 1994, 1995, 1996

$\begin{array}{llrl}\text { Year (BURN) } & 2 & 5.92 & 0.052 \\ \text { Year (CUT\&BURN) } & 2 & 30.58 & 0.001^{*} \\ \text { Year (MULCHED) } & 2 & 0.25 & 0.884 \\ \text { Year (HAND-CUT) } & 2 & 2.18 & 0.336 \\ \text { Year (CONTROL) } & 2 & 0.33 & 0.847\end{array}$

F. Years within treatment areas comparing 1994 and 1995 with 1996

1995 (BURN)
1994 (CUT\&BURN)
1995 (CUT\&BURN)

4

4

4
2.41

3.97

14.57
$0.001^{*}$

$0.001^{*}$

0.946

G. Final Model: treatment areas and year nested within treatment areas for BURN and CUT\&BURN areas.

$\begin{array}{llrl}\text { Treatment area } & 4 & 7.17 & 0.127 \\ \text { Year (BURN) } & 2 & 5.92 & 0.052 \\ \text { Year (CUT\&BURN) } & 2 & 30.58 & 0.001^{*} \\ \text { Residual } & 8 & 2.76 & 0.838\end{array}$


Table 3. Summary of models for percent plants fruiting in four treatment areas and CONTROL from $1994-1996 .{ }^{*}=$ significant at $P<0.05$.

Source

df

$x^{2}$

$\mathbf{P}$

A. Full Model for percent plants setting fruit by treatment areas and years

Treatment

Year

Residual
4

2

8
3.24

34.90

8.43

27.64

5.62
0.518

$0.001^{*}$

0.393

B. Comparison of years; 1994 and 1995 to 1996 1994 1995

2

2

Note: A final model was not constructed 


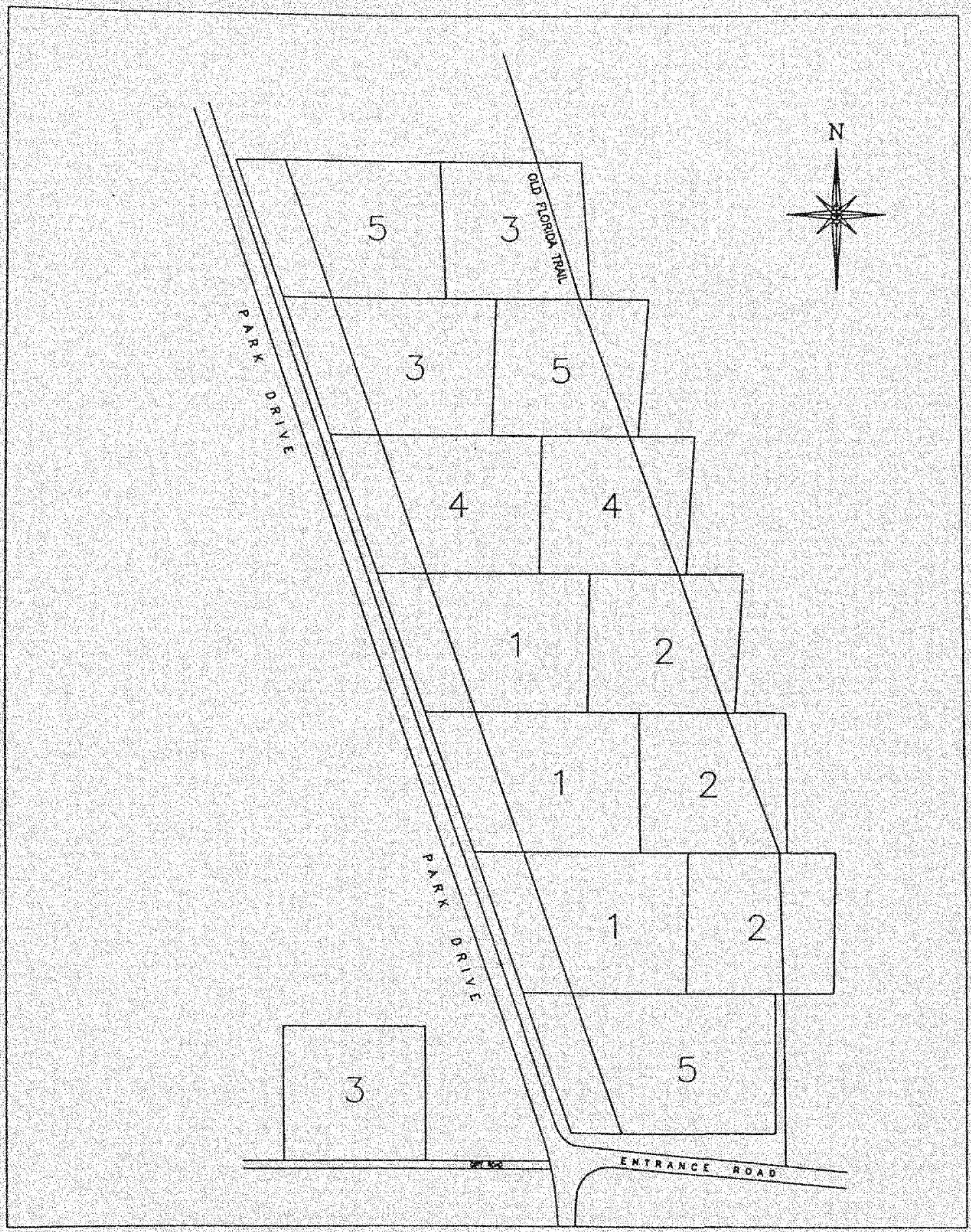

Figure 1. Research site at JDSP and location of management areas. BURN $=1$, CUT\&BURN $=2$, MULCHED $=3$, HAND-CUT $=4$, and $\mathrm{CONTROL}=5$. 
A. 1995 Population $n=157$
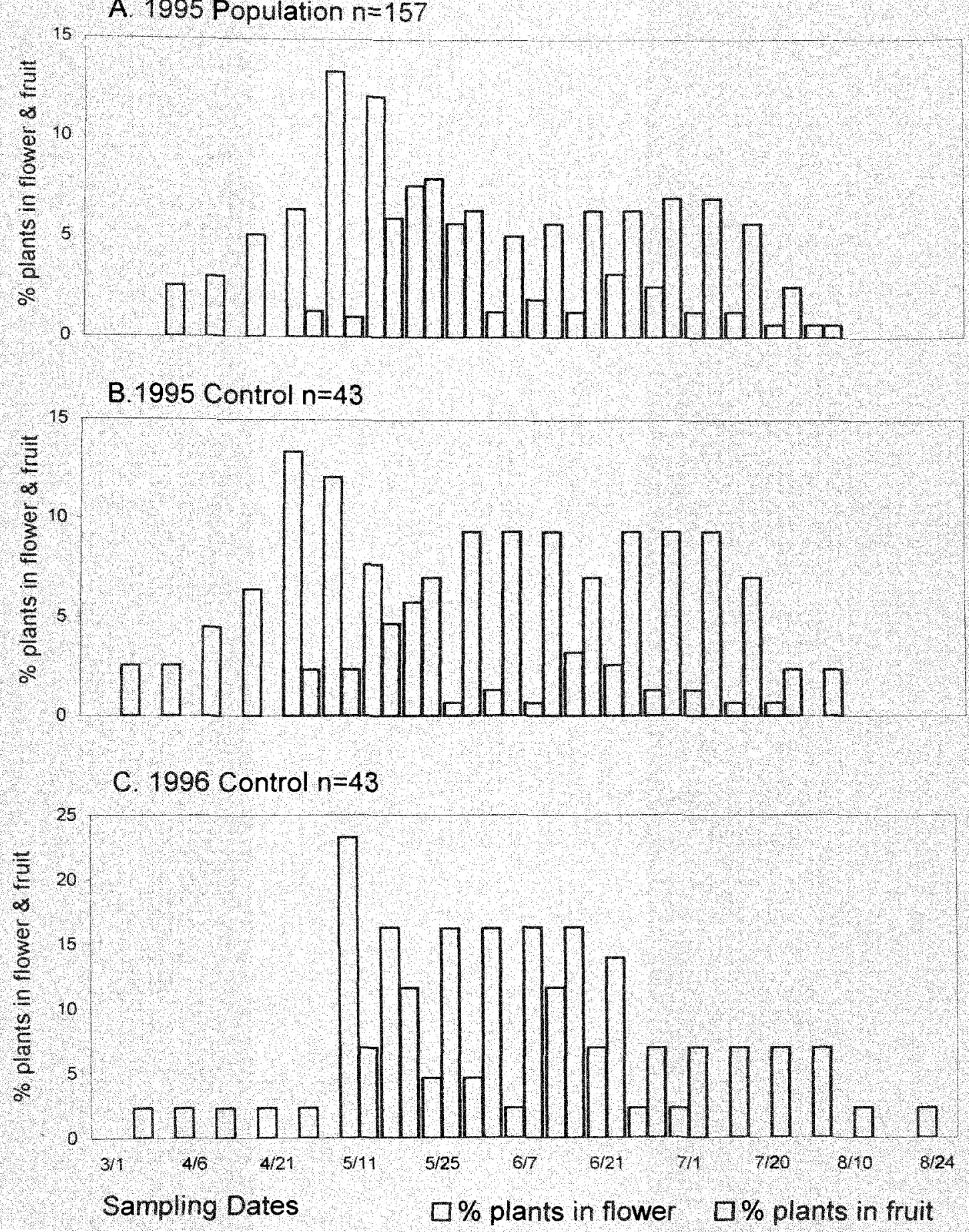

Figure 2. Seasonal flowering and fruiting phenology of Asimina tetramera in (A) Population, (B) 1995 CONTROL, and (C) 1996 CONTROL. Open bars show plants inflower and closed bars show plants in fruit. 
A. Burn Area $n=28$

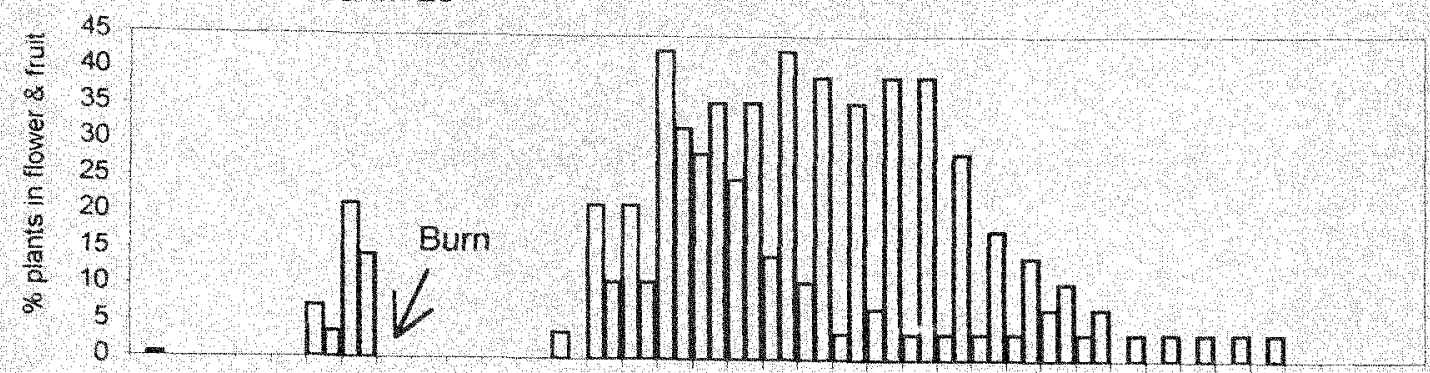

B. Cut \& Burn Area $n=49$

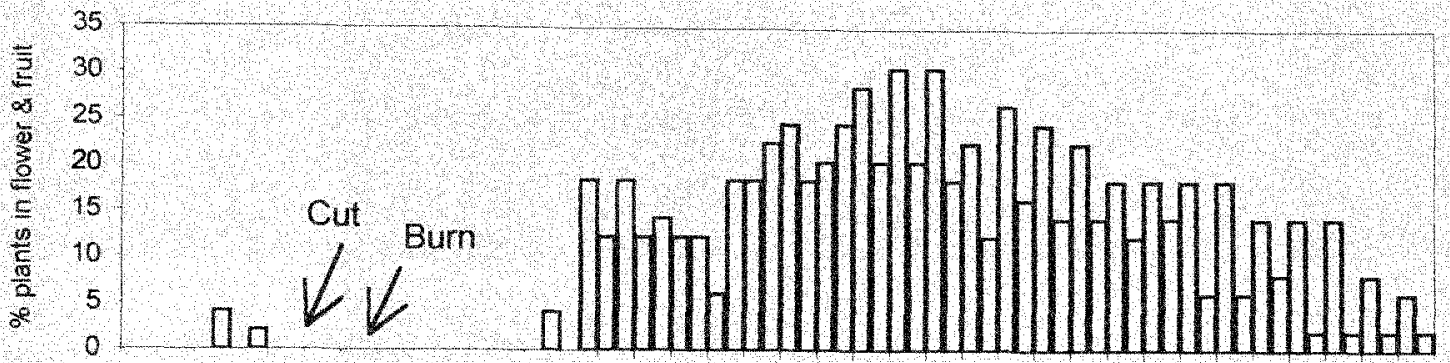

C. Mulched Area $n=15$

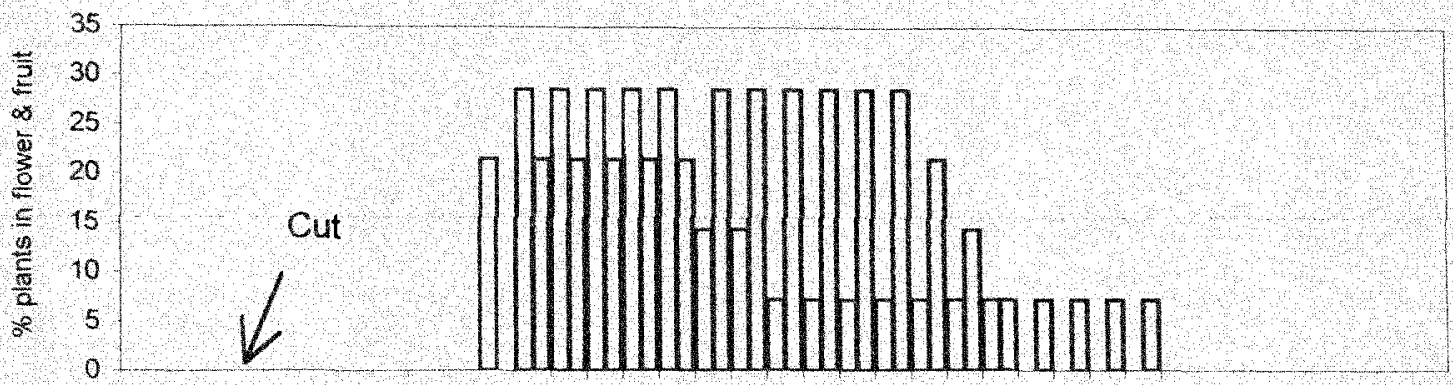

D. Hand Cut Area $n=23$

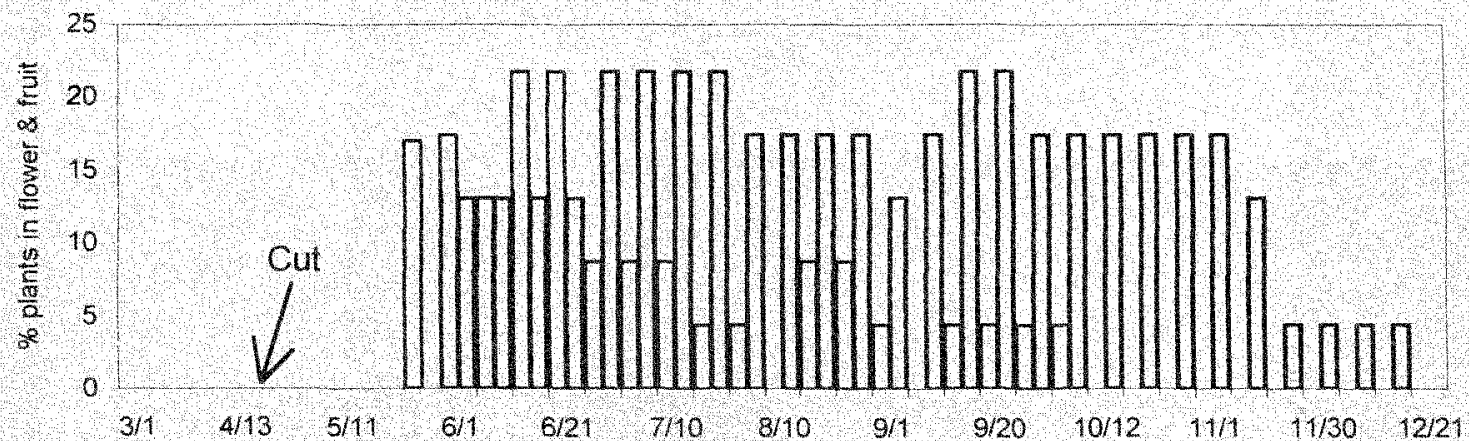

Sampling Dates $\square \%$ plants in flower $\square \%$ plants in fruit

Figure 3. 1996 Flower and fruit phenology of Asimina tetramera in (A) BURN (B) CUT\&BURN, (C) MULCHED, and (D) HAND-CUT. Open bars are plants with flowers $(\%)$, closed bars are plants with fruit $(\%)$. Note number of plants $(n)$ for areas 


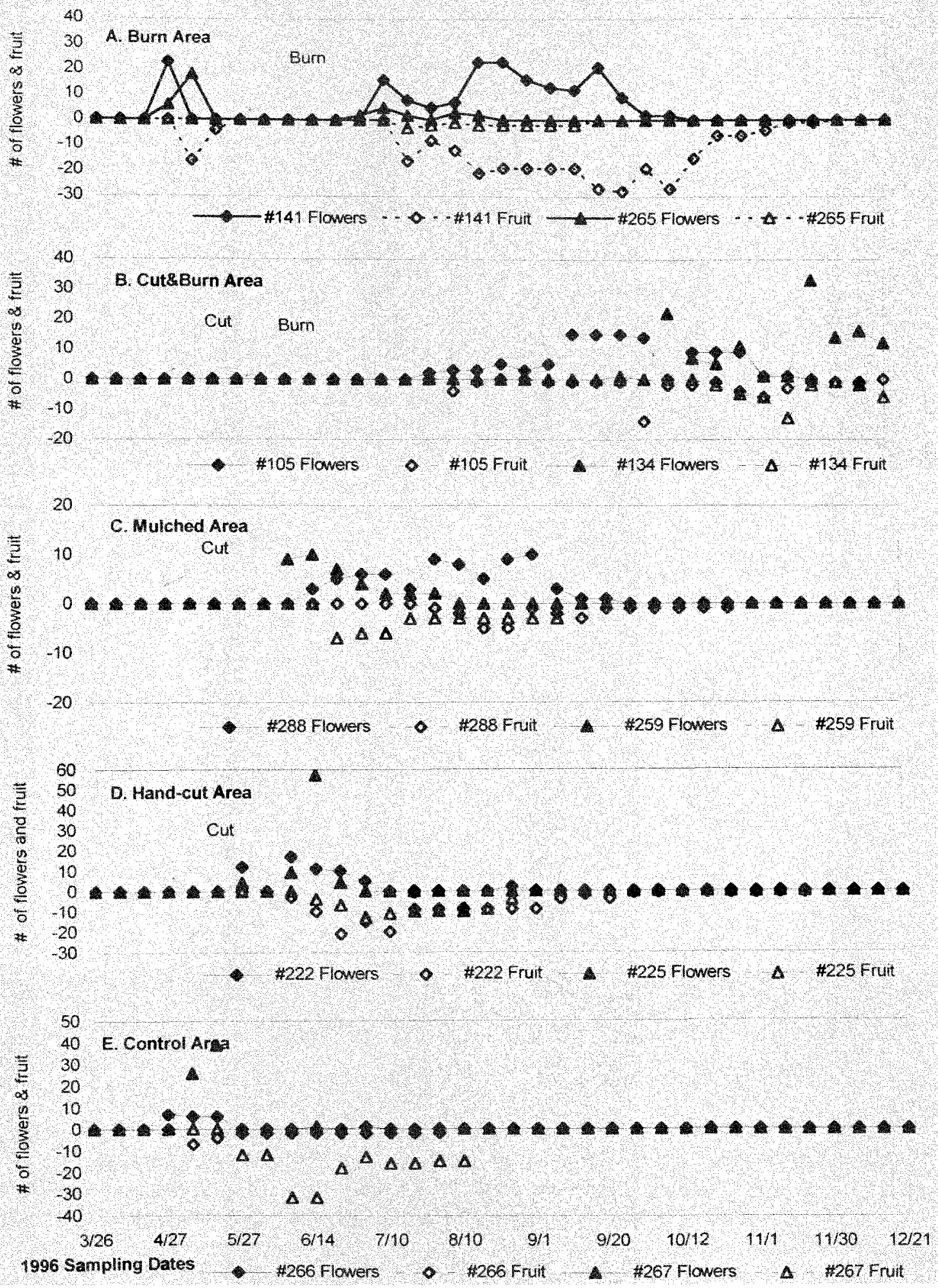

Figure 4. Flower and fruit phenology for two plants in the four treatments and CONTROL. Flower (above zero) and fruit (below zero) patterns are extreme (diamonds) and typical (triangles). Flowers (closed) and fruit (open) symbols. Numbers in the legend are plant numbers. 

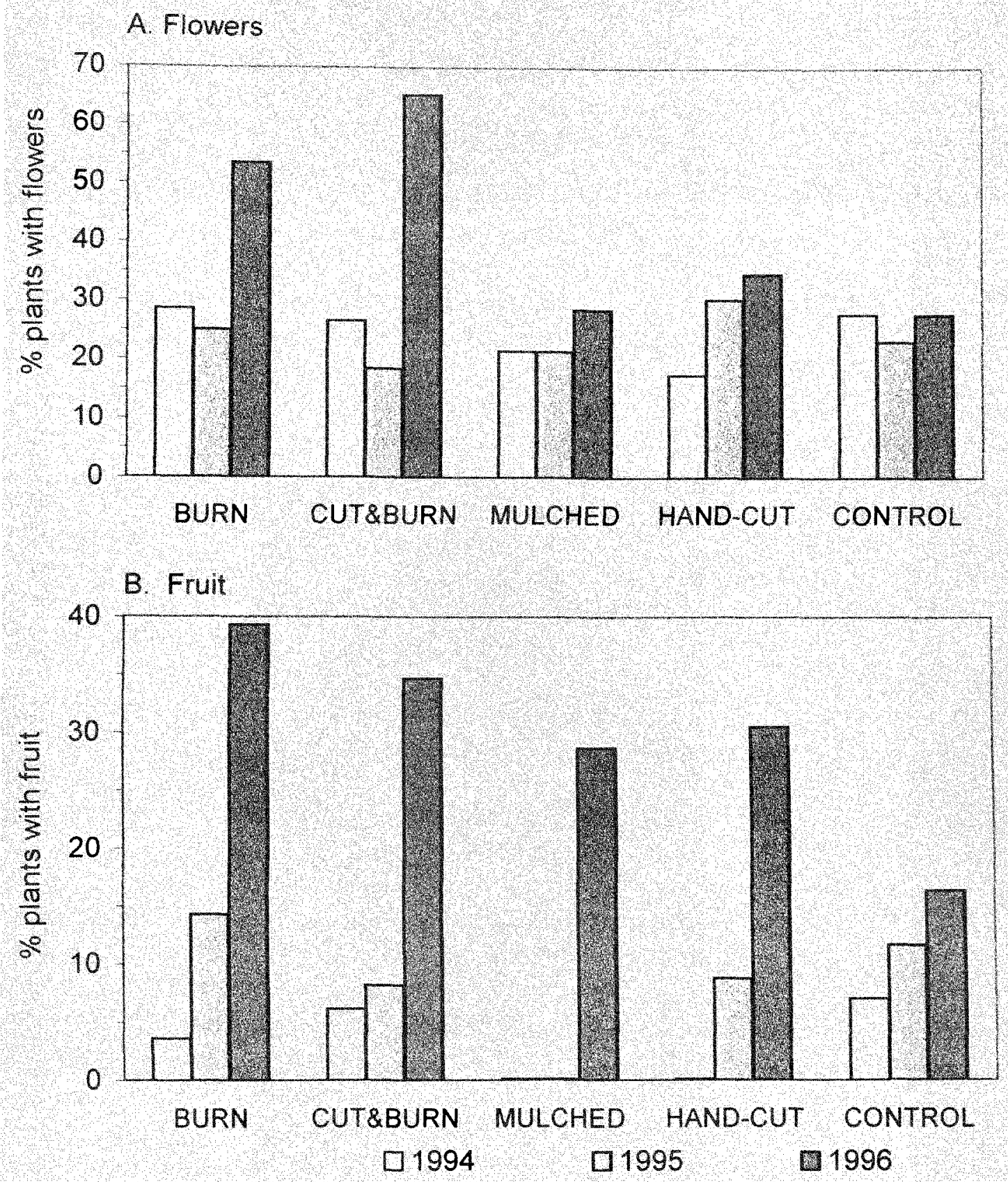

Figure 5. Percent Asimina tetramera plants with (A) flowers and (B) fruit from 1994 - 1996 at JDSP. Data in 1996 were collected after management treatments except in control area. Number of plants sampled:

burn $=28$, cut $\&$ burn $=49$, mulched $=15$, hand-cut $=23$, control $=43$. 


\section{VITA}

\section{ANNE CHENEY COX}

July 15,1941

Born, Indianapolis, Indiana

1982

B. S., Biology

Florida Atlantic University

1988

M. S., Biology

Florida Atlantic University

1993-1998

Teaching Assistant

1994-1996

Research Assistant

Florida International University

1992-1994

Adjunct Faculty

Barry University School of Adult

and Continuing Education

Miami, Florida

1989-1992

Environmental Analyst

Palm Beach County, Florida

1987-1989

Environmental Biologist

Jupiter, Florida

1982-1987

Instructional Specialist

Pine Jog Environmental Science Center

\section{PUBLICATIONS AND PRESENTATIONS}

Cox, A. C. 1994. A Comparative Study of Two Florida Pawpaws. Paper presented to the south Florida Plant Biologists, Ft. Lauderdale, FL. April 1994, and to the Annual Meeting of the FL Native Plant Society, Cocoa Beach, FL.

Cox, A. C. 1994. Resource Management of Scrub Listed Species. Poster presented at the 21st Annual Natural Areas Association Conference, Palm Beach Gardens, FL.

Cox, A. C. 1995. Reproductive Biology of Asimina tetramera and Asimina reticulata. Paper presented at the Annual Meeting of the South Florida Plant Biologists. Florida International University Miami, FL. 
Cox, A. C. 1995. Reproductive Biology of two Florida Pawpaws. Paper presented at the Annual Meeting of Florida Ecological and Evolutionary Symposium, Archbold Biological Station, Lake Placid, FL.

Cox, A. C. 1995. Reproductive Biology of two Florida Pawpaws. Paper presented at the American Institute of Biological Scientists Annual Meeting in San Diego, California.

Cox, A. C. 1995. Endangered Four-petal Pawpaw (Asimina tetramera): Response to Prescribed Burning. Paper presented to District 5, Florida Department of Environmental Protection, Hobe Sound, FL.

Cox, A. C. 1995. Resource Management of Listed Species in Sand Pine Scrub Habitat. Paper presented at the International Association of Wildland Fire and Endangered Species Conference, Coeur d"Alene, Idaho.

Cox, A. C. 1996. Resource Management of an Endangered Florida Endemic Plant Species in Jonathan Dickinson State Park. Paper presented at the Palm Beach County Native Plant Society Meeting, West Palm Beach, FL.

Cox, A. C. 1996. Seed germination of two Florida Pawpaws at the Annual Meeting of Florida Ecological and Evolutionary Symposium at Archbold Biological Station, Lake Placid, FL.

Cox, A. C. 1996. Seedling banking, seed germination and seedling establishment in Asimina reticulata, a widespread Florida endemic and Asimina tetramera, an endangered Florida endemic species. Paper presented at the American Institute of Biological Scientists Annual Meeting in Seattle, Washington.

Cox, A. C. 1997. Response of Asimina tetramera Small to resource management techniques in mature sand pine scrub in Jonathan Dickinson State Park. Paper presented at the First Annual Walt Dineen Society, FIU, North Miami, FL.

Cox, A. C. 1997. Flowering and fruiting response of Asimina tetramera Small following resource management of mature sand pine scrub in southeast Florida. Paper presented at the 24th Annual Natural Areas Conference and Exotic Pest Plant Conference, Portland Oregon. 